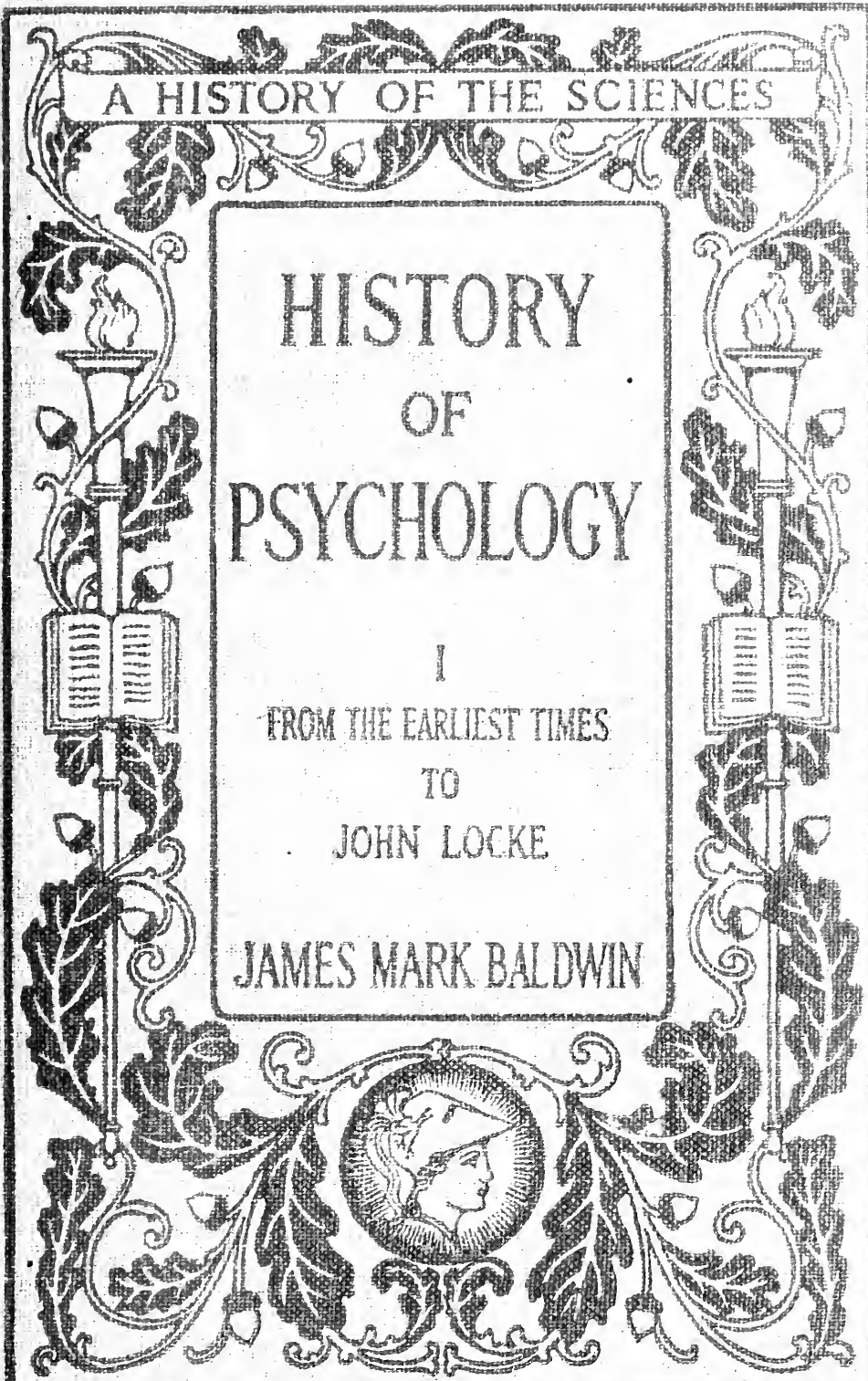




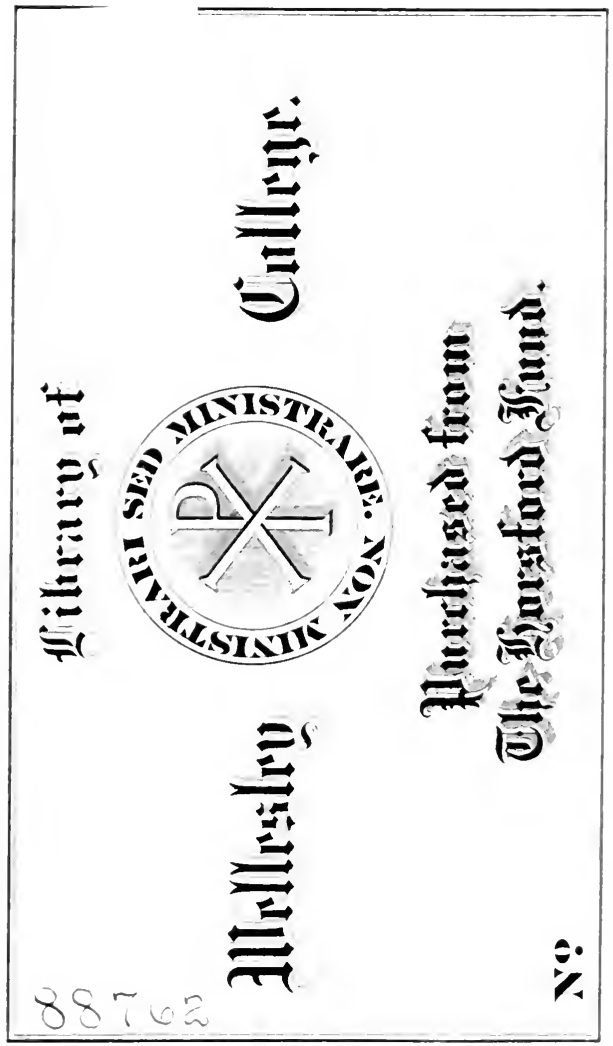









\section{BY THE SAME AUTHOR}

Handbook of Psychology: Vol. I. Senses and Intellect. Second Edition, I89I.

Handbook of Psychology: Vol. II. Feeling and Will. 1892.

Elements of Psychology. I893. Second Edition, tenth thousand.

Mental Development in the Child and the Race. Third Edition, 1907.

Development and Evolution. I902.

Social and Ethical Interpretations in Mental Development.

Fourth Edition, 1907.

Dictionary of Philosophy and Psychology. 3 Vols. in 4 Parts. Edited (with an international corps of contributors) by J. MARK BALDWIN, I9OI-5.

Story of the Mind.

Fragments in Philosophy and Science. Collected Essays.

Thought and Things; or, Genetic Logic. Vol. I. FuncTIONAl Logic, OR Genetic TheORY OF KNOWledge. I906. Vol. II. Experimental Logic, or Genetic Theory of Thought. I908. Vol. III. Interest AND ART. IgII.

The Individual and Society. I9I0.

Darwin and the Humanities. Ig09. 



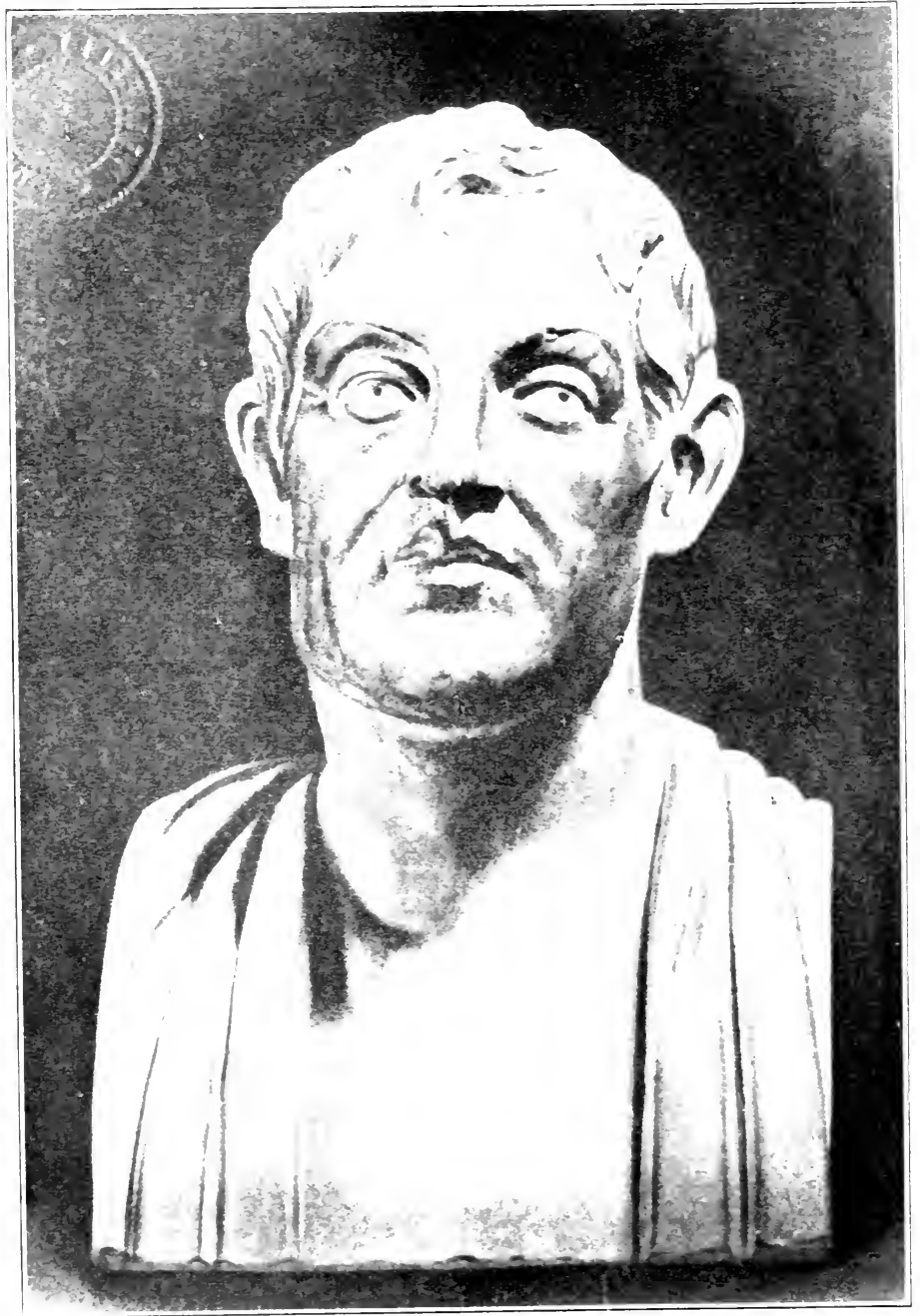




\section{HISTORY}

OF

\section{PSYCHOLOGY}

\section{A SKETCH AND AN INTERPRETATION}

BY

\section{JAMES MARK BALDWIN}

$$
\text { PH.D., D.Sc., LL.D. }
$$

FORMERLY PROFESSOR IN TORONTO, PRINCETON, AND JOHNS HOPKINS UNIVERSITIES; PROFESSOR IN THE NATIONAL UNIVERSITY OF MEXICO

FOREIGN CORRESPONDENT OF THE INSTITUTE OF FRANCE 4

\section{Volume One}

From the Earliest Times to John Locke

WITH ILLUSTRATIONS

G. P. PUTNAM'S SONS NEW YORK AND LONDON Tbe Kntckerbocker Dress 
COPYRIGHT, I9I3

BY

G. P. PUTNAM'S SONS

$8876 \%$

Srratere

This series is published in London by

The Rationalist Press Association, Limited

Tbe knickerbocker press, Rew Work 


\section{To}

\section{EZEQUIEL A. CHÁVEZ}

PROFESSOR, DEPUTY, FORMERLY UNDER-SECRETARY

OF PUBLIC INSTRUCTION AND FINE ARTS IN

MEXICO; A ZEALOUS PATRIOT, A

PROFOUND SCHOLAR, AND

A LOYAL FRIEND 



\section{PREFACE}

THE proposal to prepare the History of Psychology for this series appealed to me for other than the usual reasons. In the first place, singular as it may seem, there is no history of psychology of any kind in book form in the English language. ${ }^{x}$ Some years ago, I projected as Editor a series of historical works to be written by various authorities on central psychological topics, the whole to constitute a "Library of Historical Psychology." These works, some twelve in number, are in course of preparation, and certain of them are soon to appear; but up to now no one of them has seen the light. The present little work of course in no way duplicates any of these.

In French, too, there is no independent history. The German works, of which there are several, ${ }^{2}$ had become somewhat old when

${ }^{x}$ Since this was written the History of Psychology, Ancient and Patristic, by G. E. Brett (1912), has appeared; and Prof. Dessoir's Abriss, mentioned below, has been translated into English.

"The titles are given in the list of "Sources" at the end of Vol. II. 
last year two short histories appeared, written by Prof. Dessoir and Dr. Klemm. I refer to these again just below.

Another reason of a personal character for my entering this field is worth mentioning, since it explains the scope and method of the present sketch. I had already prepared much of the same material for a course of sixteen lectures, given in my capacity of Special Professor in the School of Higher Studies of the National University of Mexico (April to June, I9I2). These lectures have been entirely made over, in being thrown into book form; but the original purpose appears both in the plan and in the essential idea ruling the historical interpretation itself. The point of view adopted-that of a parallelism between racial reflection and individual thought, which leads to an account of the history of psychology considered as the rise and interpretation of the mind-term ${ }^{\mathrm{x}}$ in the dualism of mind and body-this point of view I have been interested in carrying out. The merely narrative sort of history-writing-useful as its results aremakes no appeal to many, among whom I count myself. In a subject like psychology it is peculiarly futile, since the views and theories of men

${ }^{x}$ It leads to the consideration of physical science as the development of the theory of the matter-term of the same dualism, a correlation merely hinted at in certain places in passing. 


\section{Preface}

cannot be ascertained and reported as earthquakes and battles can. They are themselves matter of interpretation. ${ }^{x}$ Had it not been, therefore, for the larger interest in the principle of interpretation, I should not have cared to undertake the task. The point of view itself is explained in the Introduction; and the results of its application are gathered up in the last chapter. It should be added, however, that the use of this principle of interpretation has in no way influenced the statement of historical fact or the exposition of theories. I hope the opinion of competent critics will confirm this assertion.

The book is to be looked upon as a sketch; no more than this. Two possible ways of treating the subject are well illustrated by the recent

I The place of Socrates and Socratic views, to note a case in point, is a matter of wide divergence of opinion, although we have two able and almost contemporary expounders. From the important place assigned to the "subjectivism" of Socrates in the present volume, opinions vary to the extreme of the omission of Socrates altogether, as by Dessoir. It would seem, however, that any plausible hypothesis as to the course of reflection would restore "Socratism," if not Socrates, to an important place. One may cite the well-known saying as to the authorship of the Iliad: "If it was not written by Homer, then it must have been written by another man of the same name." We may recognise the Socratic contribution to thought leaving aside the question of mere fact as to whether it is essentially due to Socrates himself or to "another of the same name." 
handbooks of Dessoir and Klemm, the former entitled Abriss einer Geschichte der Psychologie and the latter Geschichte der Psychologie.

Each has certain defects of its plan. Dessoir expounds the theories in their historical setting and with reference to their philosophical significance. The result, while on the whole of the highest competence, must perforce leave so much unreported or merely hinted at that the reader gets little idea of the richness of the sources. Moreover, from limitations of space, the author can give but a slight and impressionistic-seeming account of nineteenth-century scientific psychology, and that on national lines. Klemm, on the other hand, adopts the topical method, and gives us important notes on the development of views on this or that special subject. But anything like completeness in such a task is quite impossible in one small volume. As remarked above, the series projected to serve this purpose in English will have ten or twelve large volumes. Klemm's method results also in the omission of many topics, in this case naturally those in which the German psychologists have not had the leading part; as, for example, the subjects pertaining to the genetic method, its problems and results. Incidentally, it may be remarked that in these and the other German works the contributions made to the science by Germans have not been given too 
little importance-a remark not intended in a disparaging sense.

It follows that a rule of interpretation, such as that adopted here, to guide the selection and govern the estimation of particular facts and theories, is a real desideratum in a short sketch like this. I find, in the result, that the entire psychological development down to the nineteenth century scientific movement is illuminated by it and given a larger interest. This is true, I take it, because the hypothesis adopted accepts as subject of the history just the problem about which all the minor topics arrange themselves: that of the theory of the soul or self. Omissions in particular fields, and even mistakes * in the report of particular results or theories, should not impair the essential truth of the account as a whole. I have found the work of Harms, Philosophie in ihrer Geschichte, I. Psychologie, very suggestive because of the author's constant recognition of the problem of dualism.

As I have already intimated, the principal embarrassment arises from the variety of problems and wealth of results of nineteenth-century

' Mistakes which could hardly be entirely avoided. No writer-least of all the present author-could pretend to be equally conversant with the literature of all the periods, an ient, mediæval, and modern. He should expect to see some of his authorities challenged, and should welcome expert correction. 
psychology. The earlier works have generally brought the account down only to Kant or Herbart. If one includes the more recent work, the treatment must be selective. This I have frankly recognised; and in the chapters devoted to nineteenth century psychology I have reported simply what are, in my opinion, the most significant features of the entire modern movement. The selection has been made, however, with a view to illustrating further the interpretation which looks upon psychology as a body of knowledge and theory about the mental principle or self. ${ }^{\mathrm{I}}$

By preserving this conception one is able to pass in review nearly all of the relatively distinct new departures-social, genetic, experimental, affective, æsthetic-and by a partial statement of results illustrate at least their problems and methods.

January, I9I3.

$$
\text { J. M. B. }
$$

"A radical definition of psychology, for its own purposes, as the "science of selves," has been advocated by Prof. M. W. Calkins; see her historical work, The Persistent Problems of Philosophy (1907). 


\section{CONTENTS}

PAGE

Preface............................ v

PART I

PRELIMINARY MATTERS

CHAPTER I

InTRoduction : Racial and Individual Thought I

CHAPTER II

Primitive Thought. Psychosophy.............

$$
\text { PART II }
$$

EARLY UNSCIENTIFIC INTERPRETATIONS OF MIND

CHAPTER III

The Origin and Development of Dualism. Greek Speculation, First Period: ProJectivism......................

The Pre-Socratic Schools.

CHAPTER IV

Greek Speculation, Second Period: Subjectivism 56 Socrates, Plato, and the Minor Socratic Schools.

CHAPTER V

Greek Speculation, Third Period: Objectivism 72 Aristotle, Post-Aristotelian Schools, Stoics, Epicureans. The Greek Mystics: NeoPlatonism; Philo; Plotinus. 


\section{Contents}

\section{PART III}

\section{THE RIPENING OF DUALISM}

\section{CHAPTER VI}

The Patristics, Scholastics, and Arabians. The Anti-Logical Reaction : Mrsticism ...... 93

Christian and Patristic Psychology: Church Fathers, St. Augustine. The Scholastics : John of Salisbury, Thomas Aquinas, Albertus, Duns Scotus. Arabian Physiological Psychology: Avicenna, Alhacen, Averroees. The Mystic Reaction. The German Mystics: Eckhart, Tauler.

\section{PART IV}

MODERN PSYCHOLOGY-I. FIRST PERIOD TO THE NINETEENTH CENTURY

\section{CHAPTER VII}

The Interpretation of Dualism................

The Modern Schools. The New Departures: The Empirical Method, F. Bacon. The Renewal of Mysticism: the Italians, Jacob Boehme. The Individual Analogy.

\section{CHAPTER VIII}

Philosophical Psychology : Dualism, RationalISm, Dogmatism, Empiricism.......... I3I

Dualism: Descartes. Occasionalism: Malebranche. Parallelism: Spinoza. Pre-established Harmony: Leibnitz. Dogmatism: Wolff. Beginnings of Naturalism and Early Empiricism: Gassendi, Hobbes.

INDEX $\ldots \ldots \ldots \ldots \ldots \ldots \ldots \ldots \ldots \ldots \ldots \ldots$ 


\section{ILLUSTRATIONS}

PAGE

Aristotle...................... Frontispiece

Pythagoras............................ 46

Socrates............................ ${ }^{6} 6$

Plato.............................. 62

St. Augustine........................ 96

Duns Scotus...................... I08

FraNCIS BACON..................... 122

Descartes...................... I 32

Leibnitz........................ 154 



\title{
History of Psychology
}

\author{
PART I
}

PRELIMINARY MATTERS

CHAPTER I

\section{INTRODUCTION: RACIAL AND INDIVIDUAL Thought}

IN writing a historical sketch, the writer's first duty is to make clear what he is writing about. And while a definition of psychology, in its relations to other sciences and to philosophy, would be open to debate, still the general field that it includes is plain. Like all science, psychology is knowledge; and like science again, it is knowledge of a definite thing, the mind.

How mind in turn is to be defined is not here and now our task, but rather to trace the ways in which it has been defined. A history of psychology is nothing more nor less than a history of the different ways in which men have looked 
upon the mind. We are going to trace the ways in which man has historically thought about or attempted to understand the soul, mind, or spiritual principle.

It is only to put this a little differently, to say that the subject matter of psychology, when it is historically traced, is the way or ways in which men have thought about the "self"; for the self is always what mind more or less clearly means. As we shall see, this meaning is crude enough when it starts out, the self that the mind means. In the early periods, it is simply the significance attaching to things as not being dead or inanimate. Deadness or lack of animation was overlooked in primitive times; all things were found to have a mysterious sort of agency similar to that of personal agents and actors. All beings fell in one class; everything was looked upon vaguely as having an anima or indwelling soul. But when differences began to be discerned, and things were classified by their properties and behaviour, then the momentous and compelling distinction came between the objects that were really selves or conscious beings, and those that were merely dead or inanimate things. Once come, this distinction made psychology as such possible.

The development of the meaning attaching to the personal self, the conscious being, is the subject matter of the history of psychology. 


\section{Racial and Individual Thought}

The problem of psychology is the interpretation of minds or selves, and all of its subordinate problems are those pertaining to the several parts of this great whole meaning, the self; so the history deals with the course of development of this interpretation.

We may say in brief, therefore, that the science of psychology reflects the ways in which the human mind has been able at various epochs to apprehend or interpret itself; and that the history of psychology is the history of the modes in which these attempts at interpretation have taken form. It is the history of the more or less systematic forms of reflection upon selfconsciousness.

I say reflection upon self-consciousness, because it will not do to say self-consciousness simply, without further explanation. All adult human beings are conscious of self in some sort, and so were primitive men-endowed with the ability to judge objects to be different from and remote from themselves. But such consciousness, or self-consciousness, is not itself sufficient; it must pass into reflection. Not only to be conscious of self, but to have some sense, impression, or idea of what the self is, is necessary to give the "interpretation" which is available for history. This means that the self must take in or apprehend that it is thinking of itself in a certain way. Let us illustrate. 


\section{History of Psychology}

Suppose we say, as we must, that the early Greek philosophers, Thales and the others, did not have a refined or clear view about the self; that is, that their psychology was crude and undeveloped. This means that if one of them had been called upon to exp ain what he understood the self to be, he would have given what we would now call a vague and insufficient reply. He would have pointed to some fluid and subtle physical agent, saying that the self or mind was like that. He would not have distinguished between mind and matter. But he would still have been personally self-conscious. He would have distinguished between himself and things, and between himself and other selves. His limitation would have been that he could not mean by the self what later thinkers could mean; he could not interpret it as they did. When he talked about self, describing the fact of his own self-consciousness, it would have been in terms showing that his thought on the subject was crude and lacking in essential distinctions.

It will be of interest to define our topic in this way; for when we consider that it is the human self that each of the great thinkers sought to understand and interpret to his fellows, we see that their attempts, taken in their succession, will show the progressive development of what we may call racial or social self-consciousness. They will show, each in turn, the type of thought 


\section{Racial and Individual Thought}

about the self which is fixed in a society or race as its understanding of its own nature and faculties. A distinction must be made, indeed, when we interpret human institutions, between those customs, rights, etc., which are spontaneous, due to gregariousness, natural imitation, tradition, etc., and those which are due to deliberate co-operation, thought, interpretation of nature and man. These latter reflect directly the way individual men are at the time thinking about and interpreting the self, one another, nature, God. The history of religion, for example, is a history just as that of psychology is, of the ways in which men have interpreted self-conscious beings-in this case superhuman spirits: God, or the gods-and religious institutions vary with these interpretations. The deity cannot be thought of as more refined or more moral than the interpretation of the self at the time will allow. If the self consists of "thin vapour," then God as a self must be thin vapour also. The social interpretation shown in institutions follows upon that of the individual thinker; it cannot anticipate the latter nor can it surpass it.

Our history, then, becomes valuable as showing the stages in the evolution of racial selfconsciousness. All along we find that social life-religion, politics, art-reflects the stages reached in the development of the knowledge 


\section{History of Psychology}

of self; it shows the social uses made of this knowledge.

An analogy is current between racial evolution and individual development; we hear of the "childhood" of the race, and of its growth from childhood to mature manhood. We now see that there is more in this than mere analogy or a popular figure of speech. When men are thinking of themselves simply or "childishly," and are building upon such thoughts institutions of like simple and childish character, then there is a real childhood of the race. And when, with the development of finer thoughts and interpretations of personality, institutions and racial things in general grow more complex and refined, then we may say, in more than a figure, that the race is growing up into maturity. It suggests itself, indeed, that in social evolution we may see a re-statement of the great stages of individual development; that individual thought may show stages which recapitulate those of racial evolution-a parallel similar to the "recapitulation" recognised by biologists in the evolution of organisms. The individual's development in consciousness of self recapitulates, we should then say, the evolution of self-conscious reflection in the human race.

Such a problem becomes complicated when we deal, as we do in the history of psychology, with the development of reflective self-conscious- 


\section{Racial and Individual Thought}

ness; for we are not writing a history of human institutions, but of a human science and its effect on institutions. To get any advantage from such a principle, we should have to discover that the racial stages in the interpretation of the self, culminating in the scientific and philosophical interpretation, have been unrolled "concurrently," or in the same serial order, with the stages of development of individual selfconsciousness.

Put in this way, the problem becomes for our purposes the following: Do the racial ways of thinking of the self, seen in the theory or science of the mind known as psychology, show results of a progressive character which are in nature similar to those reached by individual thought? -and this despite the fact that these racial thoughts occur in the minds of single men, who are themselves full-grown and reflective? That is, to put the question concretely, why do we find Thales, himself adult and reflective in thinking about the self, to represent so simple and crude a. stage of racial interpretation?-and what is the rule of progress in succeeding epochs, whereby later representative thinkers achieve higher and more refined results? Is it the same rule of progress as that shown by the individual's growth from crude to mature self-consciousness?

In answer to this, we may say that the facts, on the side of the individual, upon which the 
parallelism is based, are clear. We find the facts of the development of the individual's consciousness of self sufficiently well known. The child, as recent genetic psychology has shown is entirely dependent upon society for the materials of his thought of self; his thought; is dependent upon the thoughts already current in his social circle. He absorbs what society already thinks; and his originalities, in the way of further refinement, are slight. He imitates social "copy," and absorbs social tradition. The character he has in being a self, at whatever stage of development, and the character he gives to the self, in his thought about it, are different things. Just as, in the case of Thales, we say that the philosopher had a mind full-grown for reflection, but was still dependent upon society and its institutions for the material of his thought; so also the maturing child's thought of self, at each stage, is what he gets from his social environment, and makes use of to the extent of his ability. The philosopher and the child each uses the social sources of knowledge to the best of his ability. But however great his ability neither the one nor the other can create something out of nothing.

The reason of the close concurrence between the individual's progress and that of the race appears, therefore, when we remember the dependence of each upon the other. The indi- 


\section{Racial and Individual Thought}

vidual can think in this way or that only provided the race in the midst of which he lives already thinks, or thinks "toward," the same result; and the racial thinking in this way or that is only what it is because earlier individuals have thought in this way or that. So we should expect no great departure on one side or the other from lines of thinking which are common to the two. The individual equips himself socially before he thinks independently; and society thinks progressively only as individuals are its mouthpiece.

To whatever extent this idea may be finally justified, it is an extremely attractive one. Here are two great movements, one that of the individual growing constantly more competent to understand himself and to communicate what he understands; and here is society, made up of a series of generations of individuals, doing precisely the same thing and doing it upon precisely the same mass of materials. It is on the surface likely that the series of critical periods in both, marked by new modes of accommodation and due to new crises of a natural, moral, and political sort, would show a general serial correspondence.

To the writer it has been surprising to see how closely the gropings of the thinkers who represent the racial undertaking, the philosophers, are explained for the historian by comparison 
with the gropings of the individual's struggle to achieve a full reflective self-consciousness. The crises are the same, the problems and embarrassments the same, the solutions the same. In a later chapter, ${ }^{\mathbf{1}}$ the matter is carried further. Our present purpose is simply to justify the use we make of the analogy in various places as we proceed. Further details of the concurrence itself will appear in the light of the sketch of the individual's progress given in the later connection.

Adopting a preliminary division of the entire history, in accordance with this guiding principle, we find the great epochs in the history of thought about the mind to be as follows:

I. The Period of Pre-historical and Prelogical Interpretation, occurring in primitive peoples, mystical and emotional in its character. It is the period of "psychosophy," 2 preceding psychology. It corresponds to the early a-dualistic and practical period of the child's apprehension of the self.

2. The Ancient or Unscientific Period, covering the development of Greek thought, which we may call the "Greek Period." It corresponds to the unreflective stage of the child's thought of self, the period of the origin of dualism. It is

${ }^{\prime}$ Chap. VIII of Vol. II.

'A term used by Dessoir, Geschichte der Psychologie (I9I I Eng. trans., I912). 


\section{Racial and Individual Thought}

unreflective in the sense that in this period the view of the self is not exact or critical, not the subject of distinct definition, but remains incidental to the larger view of the world or nature taken as a whole. It has three subperiods: the "projective" or Pre-Socratic, the "subjective" or Socratic, and the "objective" or Aristotelian. In Plato, the motives of "ejection" and æsthetic reconciliation are present, mediating the transition from Socrates to Aristotle.

3. The "Mediæval" or "Substantive" Period, so named from the fact that in it the great distinction arose between mind and body as different and distinct substances. It culminated in the explicit dualism of Descartes. It corresponds to the stretch of development of the individual which culminates in a similar dualism. Historically, this allowed of the separation of the problems of mind from those of body, and justified the rise of Psychology, the science of mind, in distinction from Physics.

4. The Modern Period, or the epoch of reflective and scientific interpretation. It corresponds to the development of the individual's reflection in which the self is both objective matter and subjective principle. The subject and object selves are distinguished. Mind and body become presuppositions of reflection: spheres of reference for all sorts of experience. 
Psychology as a science develops its peculiar body of knowledge and its exact methods of investigation.

These great divisions will constitute the Parts of our study, the last period being subdivided into two. The further justification of this division and its corroboration, as being a fair way of utilising the concurrence of racial and individual thought, will appear as we proceed. ${ }^{x}$

It results from this general plan that we are not to catalogue or even to report single theories or discoveries simply as historical facts. It is rather the conception entertained of the mental life as a whole-its principle, and its relation to the body, to the world, and to God-that we are to trace out. This gives us a single problem and a central one; the various solutions being presented in their actual genetic and historical order. Of course, the great discoveries of this thinker or that should be mentioned; but in each case they are kept subsidiary to the theory of the mental principle itself. That is, we are concerned with the science itself, its subject matter and method, not primarily with the detailed results of observation.

${ }^{I}$ For the detailed filling out of this scheme the Tables of Contents (Vols. I, II) may be consulted. 


\section{CHAPTER II}

\section{Primitive Thought: Psychosophy}

THE history of a science may be conceived in

a broader or a narrower sense, according as we place greater or less emphasis on the word "science." If we mean science in the strictest sense, the science which is developed through exact observation and experiment, often called "positive" science, the history is in all cases very brief and very definite. But if we include the more or less scientific and pre-scientific conceptions and interpretations of the subject under consideration, which have been entertained and taught, history becomes at once more extended and more vague. Astronomy was preceded by astrology, geology by cosmogony, chemistry by alchemy, medicine by magic, theology by theosophy; and in each case, the rise of positive science has meant the transition from vague mystical and metaphysical interpretations of the things observed to the sober and disinterested endeavour to discover facts and formulate laws. ${ }^{\mathrm{I}}$

${ }^{I}$ The exact requirements of the positive science of psychology are stated later on; see Chap. IV of Vol. II. 
Psychology more than any other science has had its pseudo-scientific no less than its scientific period. The occultisms, spiritisms, mysticisms, psychic magics, pseudo-religious "isms" of all times, ancient and modern, and of all races, oriental and occidental, have claimed the right to call themselves psychological. Each makes pretence to a certain way of thinking of or interpreting the mind, soul, spirit-whatever the spiritual principle is called. Each shows us how a period - a succession of men-has understood and endeavoured to explain its own mental being and activity. "This is the sort of thing we souls are," say equally the sorcerers, the ghost-seers, the religious prophets, and the speculative thinkers. "We are animated bodies," "we are warm air," "we are astral presences," "we are indivisible atoms," "we are ghosts in migration," "we are the seeds of things," "we are fallen gods," "we are pure spirit"-all these and many more are types of psychosophic opinion which have at one time or another gained currency and played their part in practical and social life. They are only by indulgence entitled to be called science.

Modern psychology, the science proper of psychology, gives us, it is true, only another interpretation. But it is based upon sounder data, acquired by safer methods, and confirmed by broader induction and experimentation. Still, 


\section{Primitive Thought: Psychosophy}

taken as a whole it sums up what we think, and think we have a right to think, about the soul or self. The knowledge of science takes the place of the guessing, conjecture, superstition, speculation of the pre-scientific views; but still, like them it is an interpretation of mind; a statement of what, do the best it can, the human mind understands itself to be.

This consideration justifies us in taking the broader view of the history of psychology. The narrower scientific interpretation of mind plays an important theoretical rôle; but it is doubtful whether it is to-day as influential practically as the mystical unscientific views which arose earlier and dominated human thought for long ages. ${ }^{\mathbf{T}}$

The philosophical historian seeks to discover the rule of progress in the historical movement as a whole; to see why certain views arose before others and after still others-the entire series exhibiting the growth of man's knowledge and opinion about his own nature. If we call each view entertained at any time an "interpretation" of the mind, our question then is this: Has there been any continuous evolution of interpretation?-is there a primitive type, followed by a

I It is curious that while scientific knowledge has effectively overcome mystic and occult views in other provinces, in this field the latter have not surrendered, but have maintained themselves without great change. 
more rational and refined type, this in turn perhaps succeeded by the scientific type?are there genetic steps or stages arising in a continuous historical order, in the development of the human understanding of the human mind?

The historian is here confronted by a problem which has exercised both psychologists and students of social evolution. On the philosophical side, one thinks at once of the famous "law of the three stages" of Auguste Comte, according to which human thought, racially considered, passes in order through three stages, called by him the "theological," the "metaphysical," and the "scientific." Apart from the details, it is conceded by later writers that Comte's conception was a remarkable first attempt to treat the historical progress of human thought as proceeding according to law; a law by which the interpretation of the world unfolds genetically. He actually pointed out the three supposed stages of this progress. I Such attempts as that of Comte rest upon the characteristics of the various epochs of thought as actually shown in history. A more speculative endeavour to

' See the recent excellent treatment of the question by Höffding in La Pensée II umaine, pp. Io9 ff., who applies to the stages the terms "Animism," "Platonism," and "Positivism." 


\section{Primitive Thought: Psychosophy}

interpret genetically the entire historical movement of human thought is seen in Hegel's philosophy of history. ${ }^{x}$

It is evident, however, that such an attempt, if it is to be comprehensive, should not confine itself to those more systematic and explicit views of the world and the soul to which one may give the names science, metaphysics, and theology. All these considered as such show the results of reflection, or of thought thrown into more or less articulate form. As we shall see below, in its beginnings among the Ionians, philosophy was already somewhat reflective and aimed at being logical. Early religious mysteries and rites tended to take on a measure of rational formulation in dogmas. Accordingly, it is necessary to take the question further back; to inquire into the types of belief which lie in the darker periods, before the rise of those logical formulas in which spontaneous belief seeks to justify itself. The characteristics of primitive and pre-historic knowledge and culture-considered as showing crude first interpretations of nature and man - should be investigated. They are genetically preliminary to the logical and reflective types of thought.

In this task the work of the anthropologists

' Hegel, Die Philosophie der Geschichte (trans. in the "Bohn Library").

voL. I -2 
is directly available. They have attained a constantly clearer understanding of the modes and results of early racial thought - the thought of primitive man. Later on we are to take account more fully of the results. Here we may note especially the distinction emphasised in the recent work of Lévy-Bruhl, $\mathrm{xh}$, following the leading of recent genetic psychology, separates primitive thought, as being "pre-logical," from the "logical" thought of civilised man. The primitive precedes the reflective; the prelogical, the logical. If we admit that there is a stage of interpretation so primitive that it may be called pre-logical, then this period is to be recognised as coming before any sort of intentional speculation.

The results of this procedure are in striking agreement with those of the later researches in genetic psychology. Work in mental development has shown the great stages through which the normal individual mind passes in growing up to maturity. The safest and most striking distinction is that between the pre-logical period, in which the individual remains logically undeveloped, and the logical, in which the reflective powers are fully matured. The characteristics of the pre-logical are made out with sufficient clearness to serve at least the negative

$\therefore$ L. Lévy-Bruhl, Les Fonctions mentales dans les Sociétés inférieures (1910). 


\section{Primitive Thought: Psychosophy}

purpose of indicating what the individual at this epoch cannot do. ${ }^{\mathrm{T}}$

These indications confirm the idea already suggested of a general analogy, if not an exact parallel, between the two sorts of development, the individual and the racial. The individual mind goes through a continuous growth from infancy to maturity, certain stages of which are so marked as to be well designated by certain terms. Racial thought has also gone through a continuous evolution, the stages of which present striking analogies to those of the individual development.

In reaching actual results, the British school of anthropologists was first in the field. ${ }^{2}$ The outstanding principle of explanation of this school is that of "animism," the primitive man's reading of soul into nature. All nature to the savage is living, resourceful, dynamic, semipersonal; and as such it is capable of good or ill to man. The recognition of the facts of animism, however, lost much of its value as the wellfounded discovery it was, through the inability of these writers to conceive of the "soul" save

I See the detailed treatment of the writer's Thought and Things, Vol. I (1906), where this use of the term "prelogical" was suggested, and the Preface to Vol. III (I9I I) of the same work.

${ }^{2}$ See E. B. Tylor, Primitive Culture (1871); J. G. Frazer The Golden Bough, and edition (1900). 
in one way - after analogy with the civilised man. The "ejected" souls, the souls with which primitive man animates nature, could not be of different grades or modes-souls in which this or that faculty might be undeveloped, this or that interest predominant-because the ejecting agent himself, the savage, was looked upon as having always one and the same sort of mind. The genetic idea of a real evolution of mind, and of its products in social life, as seen in racial history, even when formally accepted, could not be fruitfully applied in the absence of a functional and dynamic conception of mental operations. ${ }^{x}$

In Germany, the beginning of a racial or folkpsychology was early made by Waitz and Steinthal. ${ }^{2}$ A series of later publications of lesser importance are summarised in the treatise on folk-psychology by Wundt. ${ }^{3}$ In this work the rich resources of modern research in ethnology and psychology are made use of for the interpretation of primitive thought and institutions.

${ }^{1}$ See the criticisms of the British School, somewhat overdrawn, by M. Lévy-Bruhl, in the work just referred to.

2 Th. Waitz, Die Anthropologie der Naturiölker (1870I877); H. Steinthal, Mythus und Religion (1870).

3 W. Wundt, Völkerpsychologie (1900-1909). This work is less effective because of the writer's tendency to abstract classification and schematism. See also the author's condensation of the work in one volume, Elemente der Völkerpsychologie (I9I2). 


\section{Primitive Thought: Psychosophy 2I}

It is in France, however, that a school of thoroughly genetic sociology and ethnology has been founded. Starting out from Positivist premises, the French writers have considered primitive culture from a purely objective and collective point of view. An early work by Espinas on primitive invention ${ }^{-}$(technology) traced the origin and development of practical discovery and invention, emphasising the social and religious motives in the practical life of early societies. This direction had been pursued by the later French investigators, who have formulated the principle of "collective representation," "représentation collective." According to this principle, primitive life is dominated by a body of essentially collective thought, usage, and authority, which replaces the individual types of thought and association reached by the analysis of the British school. ${ }^{2}$

The result is a view which, while too "positivist," in the narrow sense of Comtean, to be called psychological, nevertheless reacts upon the theory of savage mind and thought, and meets half-way the results of social psychology. The

A. Espinas, Les Origines de la Technologie (1897), a work not sufficiently appreciated in English-speaking countries.

2 Their results have appeared in the annual Année Sociologique, and in the works of the editor, E. Durkheim, and his associates. 


\section{History of Psychology}

mass of "collective representation," another name for "tradition" broadly understood, replaces and prevents individual thought, to such a degree that a real distinction has to be made between primitive and civilised mental processes. Savage thought is "pre-logical," over against civilised thought, which is "logical." Prelogical primitive thought is "mystical," emotional, practical, dominated by the interests of social community and utility; while logical thought is formal, theoretical, and objective, ruled by the laws of contradiction, consistency, and proof.

This outcome is further sharpened by the formulation of the "law of participation," announced by Lévy-Bruhl as the most general principle of organisation to be found in primitive thought. According to this law, all objects and persons "participate" in the mystic meaning authorised by the collective representation or group-tradition, such as that of the totemanimal of the tribe. In virtue of this common participation, objects and persons lose what we should call, in our logical modes of thinking, their singular identity, their local and temporal position, their selfhood, etc. They interpenetrate one another. All logical and objective distinctions as such go by the board; the savage thinks in terms of the larger unity of the mystic meaning and presence. Animism is a phase of this participation of personalities inter se. 


\section{Primitive Thought: Psychosophy}

Not only does primitive man not think logically, we are told; he cannot. He is pre-logical in his individual capacity no less than by virtue of the compulsion of the social milieu. He cannot "perceive" through the senses merely, nor judge identities by logical rules; the faculty of cognition as such is rudimentary: at the best it is held under by the collectivistic interests cmbodied in him as well as operative upon him.

It is held, by critics of the school, that this view overlooks important distinctions, one in particular. The fact that tradition hinders the individual savage from thinking logically by no means proves that he cannot think logically. The whole question of the relation of social meaning or tradition to individual endowment comes up. The results, socially considered, might be just what they are if human endowment considered for itself, had not changed at all since prehistoric times. It is the social factor, the tradition, that has slowly changed, constantly allowing the logical faculty, which is always present in man, to develop more fully and express itself more adequately. ${ }^{x}$

Apart from the question as to what a given

I This point is well put by F. Boas in The Mind of Primitive Man (I9I I), who adds the consideration also, that in respect to many of our civilised interests we are still about as pre-logical and mystic in our modes of thought as the most primitive savage. 
mind might or might not do in other and different social conditions, the essential point made by the collectivist school still holds good; the point that, as a fact, the thought of primitive man is collective, mystical, and pre-logical. The very emphasis on the social which is made in the definition of thought as collective takes the problem out of the domain of speculation as to the extent of early human endowment, and places it in that of social fact. ${ }^{x}$

The question of the relation of individual endowment to racial attainment gets, however, a new form of statement from the results of recent studies in social psychology. ${ }^{2}$ For it is evident that if we take a radically collectivistic point of view, we cannot adopt the distinction with which the biologist serves himself between the factors of individuality represented by "endowment" and "environment," the latter understood in terms of the physical environ-

"A claim pressed to the point of reducing all the "normative" to the level of "deseriptive" sciences; as is the substitution of a science des maurs for morale, the derivation of logical categories from rules of social usage, etc. ... It may be added that all evolutionists agree that the mental was at some time pre-logical in its capacity; it remains so in the animals. Whether then the logical arose in pre-human or only in pre-historic times, is a secondary matter.

${ }^{2}$ See the résumé given in Chap. VI of Vol. II under the heading of "Social Psychology." 


\section{Primitive Thought: Psychosophy}

ment. The biologist finds the processes contributing to endowment to end at birth, that is, when the child is physically separated from its mother; and the psychologist generally calls this the beginning of independent mental life also. But if there be factors of mental life which appear only in social conditions, as social psychologists assert, and if these conditions become effective, as they do, only after physical birth, then the mental endowment of individuality must be said to complete itself only much later. Even for biologists, physical birth is an unsatisfactory place at which to locate the beginning of "nurture," as distinguished from "nature"; for prenatal life is in many respects subject to influences from the external as well as from the uterine environment.

A purely physiological criterion in biology would have its counterpart in a purely psychical one in psychology; and this would place the mental birth, the beginning of the mental individual, defined as the social unit, at the epoch at which the individual achieves consciousness of his individuality, that is, at the rise of self-consciousness.

Putting the matter more generally, we may say that if the independent physical life is properly said to begin at physical birth, because then the formative influences necessary to physical independence cease to operate, we 
should say that independent psychic life begins only when there is a similar release of the mind from essentially formative social influences. Only then does the person take on his full mental character, becoming a fellow among fellows, as the body does when it becomes physically independent. : The person begins to know himself to be a self among selves.

Whatever the exact force of this point may be, in a field in which the distinction between endowment and acquired modification is vague at the best, we may still say that the birth of the body is no point at which to locate the birth of the fully endowed mind. The mind develops in society after birth, as the body does in the mother before birth. Many of its essential organs, indeed we may say most of themsensation being the principal exception-are absent at physical birth. They are not merely undeveloped, but as psychic organs they are absent.

This truth, I suggest, tends to justify the position of the French writers referred to above.

r There seems to be in the growth of social independence no crisis similar to that of birth in the physical life. At birth part of the entire environment-the physiological part-is radically shaken off, while the physical part proper remains. The nearest thing to this, on the mental side, would seem to be the achievement of the consciousness of self, as described by the students of social psychology (see Chap. VII of Vol. II, below). 


\section{Primitive Thought: Psychosophy}

It shows the impossibility of determining individual mental endowment apart from social conditions. The task is as futile as that of determining physical endowment apart from pre-natal conditions would be. On the contrary, we are led to the view that a collective form of mental life precedes the individual form. How the individual can think is best seen in how he actually does think in the social conditions in which he finds himself.

The presumption, then, is in favour of a theory of radical collectivism for the period of racial culture corresponding to the pre-logical period in the individual. This is astablished indeed, by the facts collected by recent observers of primitive societies. It gives raison d'être to all those forms of illogical and irrational psychosophy by which the science of psychology was preceded, and which will always remain a thorn in its side. Socially established superstitions, occult rites, mystic appearances, religious wonders, animistic and spiritistic realities, systems of "new thought" and "Christian science"-these do not make appeal to logic or recognise the demand for objective proof. They rest in collective representation; or they are sanctioned by tradition; or they represent types of affective value; or they make appeal to emotional and gregarious habits of mind. In short, they represent and find their refuge in 
practical interests in behalf of which they continue to scout the claims of the theoretical. :

I The limits of space forbid any adequate consideration of the particular forms of psychosophic interpretation. Certain of them are noted below in passing-the Orphic mysteries, the belief in transmigration, the recognition of demons, etc. The subject must remain in our treatment merely preliminary to the main topic. 


\section{PART II}

EARLY UNSCIENTIFIC INTERPRETATIONS OF MIND

\section{CHAPTER III}

Tie Origin and Development of DualismFirst Period of Greek Speculation BEFORE SOCRATES

PRojectivism.-It is commonly recognised that the first recorded attempts to explain the world are those of the Greek schools before Socrates. ${ }^{-}$There were before this, of course, the mystic and spiritistic points of view of the religious cults and mysterics whose characteristics have been mentioned in the preceding chapter. Such views were, however, bound up with a social tradition and sanction of extraordinary force; they did not allow-much less did they stimulate-any sort of independent

'Aristotle's account of these early thinkers, in his $D e$ Anima, Book I, constitutes the first history of psychology and philosophy. 
speculation on the part of individuals. The rise of speculation represented, accordingly, an enormous transition in culture, and an unheardof dislocation of interest. Its roots are to be found, no doubt, in political and geographical conditions. In certain cases, geographical conditions favoured freedom of commerce and the rise of industrial individualism; and in some cases, political conditions favoured the rivalry and competition of social and religious institutions. These, together with the embarrassment that such conditions produce for the individual, worked for results of liberty and freedom in which the motives of reflective thought found a certain scope.

That this did not extend far, even in Greece, is seen in the conditions of persecution under which Anaxagoras, Protagoras, and Socrates pursued their careers at Athens. But both politically and socially there was in certain of the Greek colonies a state of things which, in contrast with earlier mystical collectivism, could be called one of relative rationalism. There arose a degree of speculative liberty, and with it came the urgency of new problems for thought. Its factors became more and more explicit, as we are to see, and culminated in the "relativism" of the Sophists and the New Academy.

The thinkers of this early period are generally classified in groups as "Ionians" and "Ele- 


\section{The Origin and Development of Dualism 3I}

atics" (so named from their geographical origin in Ionia and Elea), "Pythagoreans," "Atomists," and "Sophists."

Later historians, however, have properly insisted upon a classification which will reflect something more important than location of birth or membership in a group. We should aim at presenting a more essential connection than that of mere locality between this thinker and that, and a more essential bond than that of mere succession between this period and that. In our view the development of the theory of the soul or self furnishes the proper clue; and in this the analogy with the development of the individual's apprehension of the self has direct application.

From this point of view, the period may be described as that of the first appearance and early development of "dualism." It opened, indeed, with a sort of speculation which was, properly speaking, a-dualistic. The world is to the race, as it is also to the individual in the earliest stages of his development, a sort of panorama of given and unexplained changes. It is simply "projected" before the eyes, given to the senses. Its explaining principles-matter, mind, God-are not in any way isolated or differentiated from one another. But it is just its principal character that it does not remain meaningless and blank; it passes from this 


\section{History of Psychology}

"projective" and a-dualistic stage into one of crude but positive dualism. In tracing this out, we reach the real significance of the movement for psychology.

Construed in accordance with this genetic principle, we find the following stages in the development of Pre-Socratic thought:

I. The "Hylozoism" of the Ionic thinkers.

II. The "Dualism" of the so-called "Early Dualists."

III. The "Corpuscular Theory" of the Atomists.

IV. The "Formal" Theories of Pythagoras and his School.

V. The Theory of the "One" of the Eleatics. VI. The "Relativity" of the Sophists, and the transition to the "Subjectivism" of Socrates. ${ }^{\prime}$

I Although this method, considered as a mode of treating the entire historical movement, is new, the interpretation of the period as one of developing dualism is not new. It will be found in the work of Harms, Die Philosophie in ihrer Geschichte, I. Psychologie, I878 (see especially p. I I2, and in detail, pp. II $8 \mathrm{ff}$.). In the recent Geschichte der Psychologie of O. Klemm, I9II, the antithesis between earlier dualistic and later monistic views is made the characteristic of the "metaphysical" psychology of the period (loc. cit., pp. I2 ff.). Accordingly, it will be plain that the exposition of the movement as one of growing dualism is not due to our special rule of interpretation, although it is clearly in accord with it. 


\section{Greek Speculation before Socrates}

I. Ionian Hylozoism. ${ }^{-}$-The Ionian philosophers sought for some single principle by which to explain the world. By Thales and Anaximenes (in the sixth century B.c.), Diogenes of Apollonia (who wrote about 424 B.C.), and Heracleitus (about 500 B.c.), "water," "air," and "fire" were in turn taken as the principles of explanation. To Diogenes the soul was warm air; to Heracleitus it was fire. Through the breath, it partakes of the eternal living fire, which is the basis of all things. Heracleitus is called the "flux" philosopher, from his insistence on change and transformation, taking place, as he said, through the identity of being, considered as fire, through all its opposites.

In common they recognised movement, change, and development, and sought to account for it by some primal principle. This led to the theory of "hylozoism," according to which all the world of reality is endowed with life, and

I It should be distinctly understood that in treating of this and of all the other "isms" of our account, it is not the history of philosophy but that of psychology, with which we are concerned. It is only the psychological bearings of a theory that we are to bring out. For the Greek philosophy as such, authoritative histories should be consulted such as Zeller, History of Greek Philosophy, and Gomperz, The Greek Thinkers (both in English translation). See also the little book of A. W. Benn, History of Ancient Philosophy (I9I2), in this series. Mr. Benn's larger work is The Greek Philosophers (1882).

vol. $1-3$ 
the living or self-moving thing is the seat of the soul.

Accordingly, we find, on the side of their theories with which we have to do, a common emphasis laid upon life. Life is the basis of all movement, change, evolution. Living beings have souls, and all things have life. The mental or conscious principle is not separated from matter: matter or hylé ( $"\left\langle\lambda_{\eta}\right)$ is always life or zoön ( $" \omega \circ \circ)$; hence the term "hylozoism."

This view represents a first step toward an interpretation which makes some note of the group of changes and processes by which living and conscious beings are characterised. It is, therefore, properly described by the term hylozoism. On the other hand, so far as distinctions of living from not-living, and mind from life, are concerned, the result is quite negative. It is consequently possible to say that it represents the "projective" stage in the development of dualism; it is not subjective, nor is it objective. Life is a sort of first thing, a crude general term within which more positive meanings are later on to be differentiated. It is the first step toward a more individual and reflective point of view - similar to that taken by the child-leading away from the social or collective zoommorphism of racial interpretation. But it retains the

ICf. Chap. VII of Vol. II on the "projective" stage in the individual. 


\section{Greek Speculation before Socrates 35}

essentially zoömorphic content, for which hylozoism is only another name.

II. The Early Dualists.-Within the same school, a group of men went further and worked out a series of views to which the term dualism has been very properly applied by the historians of the period. The great names to be mentioned are those of Anaximander (cir. 566 B.C.), Empedocles (455 B.c.), and Anaxagoras (500-428 B.c.). Each of these thinkers pointed out contrasted or opposing principles in the world. Anaximander postulated the "unlimited" or "infinite" ( $\therefore \ddot{z} \pi \approx$ z $p$ ov) as a positive something over against the limited elements of things. To Empedocles "love and hate" were the principles of opposition-an anthropomorphic rendering of attraction and repulsion. Finally, Anaxagoras gave the name spirit (yoiss) to the vital or formative principle, contrasting it with matter.

Not only in these general principles of opposition, which in a sense did what the one principle of life had been called on to do, do these thinkers differ from the hylozoists; but also in their views as to the concrete matter of the world. They recognise in nature certain qualitatively different elements whose composition, under the action of general principles, produces things. The qualitative elements for Anaximander are the "warm" and the "cold," the "dry" and the 
"wet." Empedocles postulated four different elements: fire, water, air, and earth. But fire and air are the warm and the cold over again, and water and earth are the wet and the dry. These elements are undecomposable although composite. They also fill space; there is no such thing as the "empty." Anaxagoras also explains all the phenomena of nature in terms of the union and separation of qualitative elements. Man according to Anaximander was evolved from aquatic animals.

The philosophy of these thinkers, thus briefly described, leads to a new stage of the dualism which the science of psychology presupposes; and this in two ways.

In the first place, the postulation of natural qualitative elements serves to solidify the external or objective pole of the growing distinction between the soul and the outer world. It is a step torrard naturalism-torrard a causal explanation of change in nature. It is a clarification of the mystic and vitalistic explanations of the hylozoists, tending to express itself in dualism.

In the second place, this reacts to produce a similar clarification or definition on the side of the self, the subjective term or pole. If the more objective is in a measure divorced from the less objective, the external from the internal, this will result in a further statement on both sides. Accordingly, we find not only the recognition of 


\section{Greek Speculation before Socrates}

the elements as external and distinct from one another, but with this that of the general principle of movement or change by which the combination and dissolution of the elements is accomplished. And it is here-in Empedocles, and more explicitly in Anaxagoras-that the further phase of dualism asserts itself. This principle is "spirit," reason, voũs.

The origin of this opposition and its further development are of great interest from the point of view of the analogy between the racial and individual processes. The child is led by the stress of life, by the need of adaptation, to the recognition of a certain stability, lawfulness, and uniformity in the external world. This uniformity conditions and controls his thought and action. And it is by this movement toward the definition of the objective that the contrasting phase of experience, the inner quasi-subjective phase, is clarified in turn. The moving principle behind the regularity and uniformity of things, the raison d'etre of ordered change, is something that is to shape itself as the self or soul.

This we see reproduced here in the development of reflection. It is the further working out of a motive present in the mystic interpretation of primitive peoples. Animism and mystic participation are readings, by a sort of social projection, of a crude soul-life into the changes of nature. Here we see its counterpart 
in early reflection. The world of things is exhausted in the combination and dissolution of elements; how is this combination and dissolution to be accounted for? By the second and less definite principle which the dawning world-dualism implies-the soul.

It has been very commonly said that in this dualism, which gives explicit recognition to the principle of "spirit" or vo'ss, over against matter or $\ddot{j} \lambda \eta$, Anaxagoras anticipated a full dualism, even that of Descartes. This is, however, a grave mistake. The facts, no less than the interpretation they should bear, dispute this. We cannot here anticipate more than the general significance of the Cartesian dualism; but that will suffice. Descartes reached the thought of the actual separateness of two substances, mind and body, having disparate characters, thought and extension, and incapable of direct interaction between themselves. The contrast to this afforded by the theory of Anaxagoras is instructive. Instead of two substances, having specific characters, this thinker makes mind the basal principle of order and unity in the material no less than in the spiritual world-a conception developed by the Pythagoreans. Instead of separation and non-interaction, he postulates immanence and union. The problem for Anaxagoras is, what is the one principle of all nature? That of Cartesianism is, how can the 


\section{Greek Speculation before Socrates}

appearance of interaction between mind and body, in particular cases, be accounted for, despite their absolute separation? The philosophy of the Greeks worked out the separation of mind and body; that of modern times seeks to bring them together again. ${ }^{x}$

More positively stated, the dualism reached by Empedocles and Anaxagoras may be described as an important step toward subjectivism. It did not, however, reach the full subjective point of view, seeing that the positive determination reached was on the side of the objective, the external in nature; where the elements were qualitatively determined and the underlying principle was that of space. $^{2}$ The inner or mental principle remained largely negative: a sort of speculative resort, or at best a refinement on matter. The subjective as a conscious life was not yet defined.

This appears in the fact that the two great problems which exercised the Greek mind subsequently to this were not strictly those of dualism. We find the problem of "the one and

I The same difference exists between the substantive form of dualism of later Christian theology and that of the mystic spiritualism of Alexandria. Modern theology is embarrassed by the contradiction involved in the resurrection of the body; but the Apostle Paul could say without feeling the contradiction, "it will rise a spiritual body."

"Like the "thought" of Parmenides, the "nous" of Anaxagoras was made one with empty space. 
the many" growing constantly more exacting and imperative. It was solved by the theories of the Atomists and Pythagoreans. The other problem-connected with the former-was that of the unreliability of the senses worked out in turn by the Eleatics and Sophists.

The special doctrines of this group of thinkers were varied and interesting; we have space only to mention certain of them.

The evolution of the world, including man, is described as a single and continuous process. It is due, according to Empedocles, to the action of love and hate. Man is the latest and highest product of this derelopment; his immediate cause, according to Anaximander, is the action of the sun upon the earth working through lower forms of life, from the fishes upward. According to Empedocles, the plants are still earlier forms of life, produced by the action of love which orercomes the disorganising forces of hate. ${ }^{\mathbf{1}}$

Empedocles also held to a theory of "transmigration" of souls. A series of bodily forms is imposed upon the soul by the action of hate. It is the function of love to free the soul from its bondage to this wandering life, and restore it to its divine place.

I The organs were separately formed and were brought together in many combinations by the action of love; from which those best adapted survived. Thus ha hit upon the idea of natural selection. 


\section{Greek Speculation before Socrates 4I}

Perception to Empedocles was due to the action upon the senses of emanations from things. He attributed perception to plants. Truth was secured through sense-perception in accordance with the principle that "like acts only upon like." We can know things because we, like things, are composed of material elements organised by love and hate.

In Anaxagoras, the principle of spirit, or yoũs, already spoken of, takes the place of the love and hate of Empedocles. As opposed to the elements of things (called by Aristotle "seeds," o $\mu_{0} \circ \mu_{\text {sep }}$ ) which are material, the soul is simple, identical, unmixed. It brings movement, order, and form in to the mixed materials. It is, moreover, the principle of reason, from which the ends found in nature proceed, acting in opposition to accident and blind necessity. It is also active, not merely intelligent; it is the moving, working principle, seen not in the living person only but in all nature. In Anaxagoras, too, the concept of evolution becomes more clear, as a process of real advance, of historical creation, than as one of mere distribution and redistribution of elements. ${ }^{x}$

I Anaxagoras is criticised, however, by Socrates (in Plato's report in the Phado, 96 ff.) for omitting finality, $i . e$, the end which is the "good," from his account. It is true that the soul-doctrine of Anaxagoras lapses into physics, instead of leading on to ethics. 
The single soul is the form taken by spirit in a given body of material elements. The plants have "dark" or immature reason, endowed with sensation, desire, etc. Truth is reached by reason working upon opposition and distinction; it is not attainable by the senses alone.

Summing up the position of dualism among these thinkers, we may quote Mr. A. W. Benn: "Anaximander could regard the heavenly bodies as blessed gods, Xenophanes could ascribe omnipotence and omniscience to the material world. Empedocles could represent love and strife as elementary bodies"-all this in explaining how "pure reason could have been identified with pure space" by Parmenides and Anaxagoras (A. W. Benn, Ancient Philos., p. 42).

III. The Greek Atomists and the Corpuscular Theory.-In Leucippus (cir. 48 o B.c.) and Democritus (460-36r B.c.), the leading Atomists, the definition of the objective pole of the mindmatter dualism was carrice forward. It reached such a positive statement in the direction of naturalism and mechanism that the theory, especially as presented by Democritus, is usually called "materialism." It advanced the concept of the soul, however, only negatively; and for this reason its psychological interest is small. ${ }^{\mathbf{1}}$

I The classical treatment is that of Lange, History of Materialism. 


\section{Greek Speculation before Socrates}

To these thinkers, the elements of the world were atoms or corpuscles, varying in figure and size, but without differences of quality. These atoms have, for Democritus, a necessary downward movement: they fall in empty space (Leucippus), faster or slower according to their size, the larger being heavier. By these atoms, thus set in movement, nuclei of matter are formed, aggregates assembled, and the world of things produced. ${ }^{\text {x }}$ Bodies are aggregates of corpuscles.

The soul is such an aggregate. It is composed of round, smooth, warm, fire-like atoms. The physical body is also an aggregate of atoms warmed into life by the soul, which departs at death leaving the body inanimate.

Perception takes place by means of little images $(\varepsilon ! \hat{\imath} \omega \lambda \alpha)$ which pass to the soul through the senses. But perception is imperfect and often deceptive. The qualitative aspects of the world are due to illusion of the senses, since only quantitative differences exist. Impulse and will, the active life, reveal the reverse process -the pouring out of the images taken-in by perception.

I This is the usual account. According to Benn (Hist. of Ancient Philosophy, p. 169) it was only in the later atomism of Epicurus that "weight" and a "downward" direction of motion were attributed to the atoms; Democritus' atoms flew at random. 
The air is peopled by demons, as the popular theosophy declared, agreed Democritus; they are human-shaped images, capable of speaking, and having knowledge of human affairs.

As intimated above, these thinkers represent a departure of importance in a certain direction. They freed speculation about the external world from the intrusion of occult and vitalistic elements. They banished the moving principles - love, hate, reason-of Empedocles and Anaxagoras, substituting a falling movement, which is, of course, so far as falling is concerned, a movement without a cause. But for such a movement there must be a void, an empty space. This thought is a notable achievement in physical science; but it denies the existence, and obscures the properties, of qualitative phenomena, and with them those of the soul. It may be called an advance for psychology, therefore, only in the negative sense that it makes it easier for subsequent thought to characterise subjective phenomena as such, in so much as the external and mechanical is more sharply defined.

We cannot, properly speaking, call their view materialism. For this would be to suppose an opposition between their view and some sort of conscious spiritualism: to presuppose, that is, the dualism between mind and matter. On the contrary, the supposition that the soul is made up of smooth round atoms is only another of the 


\section{Greek Speculation before Socrates}

attempts to account for it as part of the world, composed of the same stuff as the world in general. In this, it is in agreement with preceding theories, which had also failed to isolate the mental or conscious as such.

The conception of Nature (p's: in the direction of an objective and mechanical world-order. The antithesis between nature and man, as it took form in the Sophists, is thus prepared for.

IV. Pythagoras (after 600 B.c.) and the Pythagoreans.-As multiplicity and disorder were emphasised by the Atomists, so in the Pythagorean school we find emphasis placed on the notions of unity and order. The atoms of Democritus are, as we saw, left without any ordering, arranging, or developing principle; they fall, and that is all. In Pythagoras, there is a return to the Ionic thought of a principlelove, hate, spirit, etc.- - that stands for unity and order, behind or within the multiplicity of nature; this thought was given a very remarkable illustration in the Pythagorean theory.

For Pythagoras, nature obeys and reflects the laws of "number." Every phase of phenomenal change may be supposed to follow a numerical order. As we should say to-day, every thing allows of "numerical expression"-a mathematical conception of the world. The world be- 
comes an ordered cosmos; its unity is seen in its numerical relations. Plurality is disorder; a rebellion against the order and unity of a numerical system. The essence of things consists in the numbers which express them; the numbers, therefore, are themselves essences. The Pythagoreans did not find this inconsistent with the recognition with the "early dualists" of opposites or antitheses in nature of which they made a list-one and many, rest and motion, etc.

The soul is the numerical harmony of the body, as the world-soul from which it arises is the harmony of the cosmos. Universal life is governed by number in four stages: (I) it is latent in seeds; (2) it appears in plants; (3) it becomes the "sensitive" soul in animals (located in the heart); and (4) the rational soul in man (located in the head).

The soul has three parts; reason (qpéves), intelligence (vous), and desire (0upós). The first of these, the reason, is peculiar to man; animals have the other two. This is an early attempt at classifying mental powers or faculties; but it goes no further than this.

With the point of view of order and harmony we find united a development of the Orphic doctrine of transmigration of souls. Souls go

I The name of Orpheus, the legendary founder of a mystical sect, became attached to this type of worldtheory. 


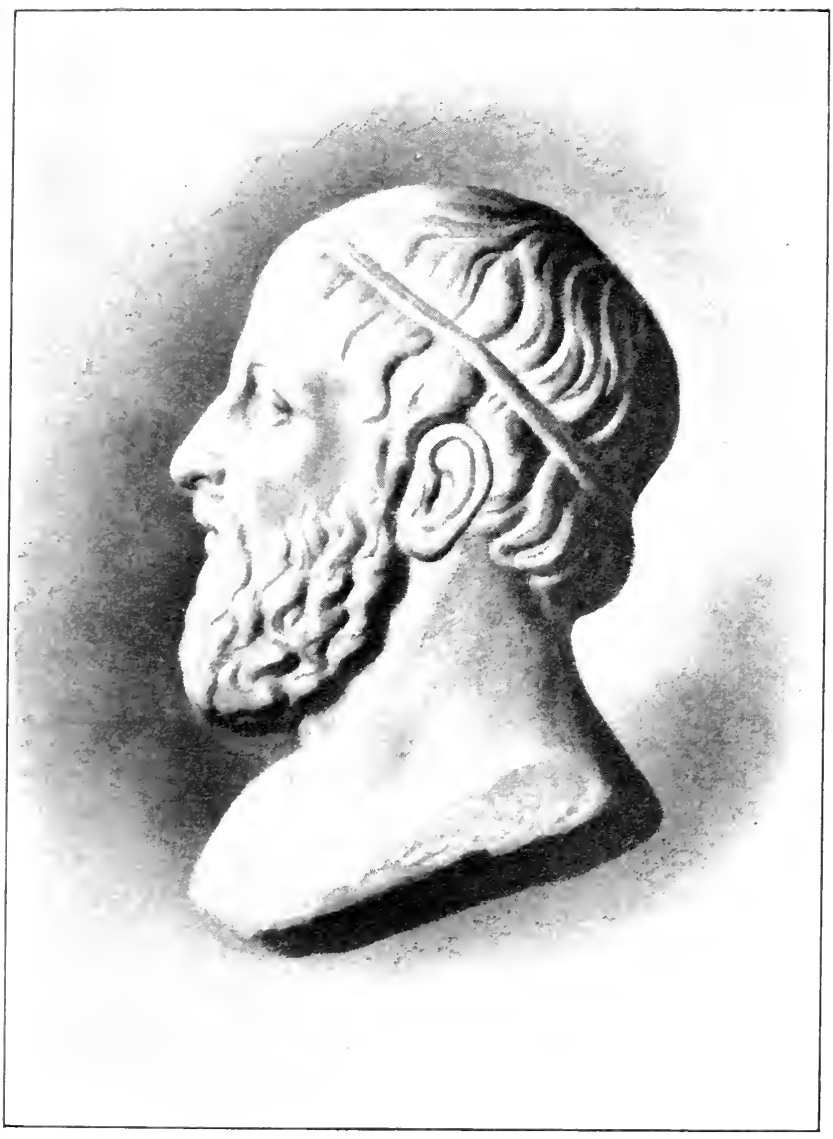

PythagORAS.

(Copyright. Reproduced by kind permission of the ()pen Court Publishing Cu., (hicago, L \& A.) 



\section{Greek Speculation before Socrates}

from one body to another, being in this sense separate existences. Demons are disembodied spirits.

There is an apparent contradiction between this doctrine and the view that the soul is the numerical harmony of a particular body. It is probable that in the Pythagorean circlea secret religious organisation-the theory of transmigration was the accepted view, answering to ethical and practical demands and maintaining the Orphic tradition.

The need of carrying out further the conception of order and harmony in a comprehensive philosophy, and of ridding it of contradictions, appeared later in the theory of "ideas" of Plato, for which the foundation is here in a sense laid. The development of a formal and unifying principle - that of number-suggests the corresponding rôle of thought or the "idea"; but it is only by vague hints that this is intimated. In the general tendency, however, away from the purely objective and pluralistic view of things to one in which the apprehension of unity and order is made prominent, and which is in some way connected with the soul, an advance toward subjectivism is to be recognised.

V. The Eleatics.-In the philosophers of Elea-Xenophanes: (cir. 540 B.c.), Parmenides

$\therefore$ Xenophanes was the first Greek philosopher to write in verse. 
(cir. 490 B.C.), Zeno and Melissus of Samos (both cir. 450 B.C.) - a further movement of thought shows itself. In them, two antitheses were clearly presented which had been foreshadowed in earlier speculation: that of "the one and the many," and that of "being and becoming." These, together with the Aristotelian problem of "matter and form," remained the critical questions of Greek interest.

So far as the problem of psychology is concerned, the definition of the mental principle, both of these antitheses have significance. Claiming that the absolute principle of things is one and not many, the Eleatics explain the multiplicity of things as "appearance" only, due to the deception of the senses. To Xenophanes, earth is the one original element. It is of infinite extension: and it is at the same time God, all-wise and all-powerful. As this principle was held to be one of fixed being, not one of change and becoming, such an interpretation of sense perception was reinforced. For Parmenides the "one"-to Melissus, infinite - was finite but eternal and at rest; it was pure space, which, like the "earth" of Xenophanes, was also reason and God.

The Eleatics dereloped both these positions. The world-principle is one; not many, as the

${ }^{x}$ Known as "Zeno the Eleatic," in distinction from the more famous "Zeno the Stoic." 


\section{Greek Speculation before Socrates}

Atomists taught. It is also fixed, perfect, changeless; not in development, as the Ionics believed. The two other schools were alike led astray by the appearance of things - an appearance due to illusion of the senses.

In this the force of the Eleatic philosophy for psychology shows itself. It brings to the fore the problem of perception and makes an explicit criticism of knowledge necessary for further theory. Without such a criticism the three alternatives of thought-Ionic, Atomistic, and Eleatic-might be reiterated again and again without end.

But the problem of perception or knowledge is one of the inner or subjective life; and in bringing it forward the Eleatic philosophers took a step toward the definition of the subjective point of view as such, represented later on by Socrates. Parmenides, although identifying soul and body in the "one," still attributed to the "one" something like consciousness.

Their theory was also in line with the doctrine of unity and order of Pythagoras, which also denied absolute multiplicity. But it sought this unity in the absolute ground of things or in God, as the Ionics had done before them; not, as Pythagoras had done, in a property of the world itself.

The potential dualism of spirit and matter disappears in the theory of Xenophanes and vol. $\mathrm{I}-4$ 
Parmenides as to the nature of God. God is both a sphere, supporting the world of material things, and also a spirit: the "perfect" in extension and in thought, the "All in One" (हิ้ \%x! $\pi \tilde{x} v)$. In this speculative "identity philosophy," we are reminded of the pantheism of Spinoza, which followed upon the dualism of Descartes, much as the pantheism of the Eleatics follows upon the similar but less well-defined dualism of the Pythagoreans. They both show the resort of the imagination to a single monistic principle.

The world of change and becoming is appearance, illusion, Schein; this Zeno demonstrates by showing the absurdities contained in the conception of motion. His famous proof that Achilles could not overtake the tortoise-because whatever the fraction of the distance traversed by Achilles, the tortoise would also have gone forward a distance in the same time-remains a classical piece of logic. Specifically the world, and with it man, is a mixture of "light and darkness": a position which shows how undeveloped the dualism of mind and matter still remains. Both together are the outcome of the one fundamental refined physical principle. "Light and dark" was about the only antithesis of a general sort in nature that had not already been invoked!

A sharp distinction was made, however, 


\section{Greek Speculation before Socrates 5I}

between reason and sense. As perception is illusory, change and becoming are not real but only apparent; but as reason is the organ of truth, unity and being are absolutely disclosed by it. The reason grasps the being of things and establishes, for Parmenides, the identity of thought and its object, that of reason and extension.

VI. The Sophists.-In the group of men called Sophists, or "wise men," $x$ the decay of speculation followed from its own general tendencies. The Sophistic period is one of denial and lack of confidence. This showed itself in a temper of mind to which certain of the implications of earlier thought were congenial.

First, the doctrine that the senses deceive, stated by the Atomists and Eleatics in a form that made all perception a mirage and motion impossible, was carried out by the Sophists in the theory called in later speculation that of the "relativity of sense qualities." All external reality or truth is relative to the observer, who apprehends the world through the medium of the senses; there is no reliable general knowledge of nature secured by perception. Justice and morals cannot be founded on a supposed objective order of nature.

I They were a class of travelling teachers who took money payment. They prepared wealthy young men for careers requiring skill in disputation and rhetoric. 
But this is not all. Why, ask the Sophists, is reason any better? What right have the Eleatics to say that the absolute can be reached by reason? This, too, is vain; there is no way to reach any independent truth, either sensible or rational; all rests upon the experience and nature of man.

Hence the positive position to which these negations brought certain of the Sophists-the only resort is that which appears to the man, his fleeting and circumscribed experience. Homo mensura omnium: "man is the measure of all things." This is the motto of Protagoras (48O4 I I B.C.), and Gorgias (427 B.C.), ${ }^{x}$ the latter the dialectician who argued that there is nothing, and, besides, we could not know it if there were, and we could not communicate it if we knew it.

The Sophistic period is one of clearing up or stock-taking. It represents the bankruptcy of the old ways of thinking. The mind finds itself embarrassed by the futilities of partial and unsuccessful systems. Its mcaning for psychology, however, is not at ali negative; it is very positive.

The retreat of thought into the man himself, into his circumscribed consciousness, into the

${ }^{1}$ Their contemporaries, Hippias and Prodicus, held a more conservative position as to the value of objective knowledge. 


\section{Greek Speculation before Socrates 53}

empirical life, is in itself a new point of view, and the beginning of a new method. Give up, say the Sophists, the mere "say so" of dogmatic assertion, the mere preference for this system or that, and be content with what you find within you.

To be sure, the Sophists did not themselres apply such a method or develop the new point of view. They were in a true sense sceptics; the satirists of the old, not the prophets of the new. But nevertheless they indicated the platformcleared of its broken furniture-from which the prophets of the subjective were to speak, Socrates first of all.

The Sophistic stand is, for the development of racial interpretation, what the dawn of the subjective era is for that of the thinking individual. The mind is, in a sense, thrown back upon itself through the ineffectiveness of its first efforts to understand things. It finds in itself a mass of material of first-hand immediate quality, a mass of affective and active data: feelings, efforts, the contents of the practical life. All this remains a direct possession, after the objective illusions and appearances of sense and reason are discounted. The "subjective" becomes a sphere of reference, a resort having its own characters, sanctions, and modes of being; it is a term that stands in opposition to the other term, the external and foreign, of 


\section{History of Psychology}

whatever sort. The dualism of "subjective and objective" is preparing itself.

In our opinion, this is the significance of the Sophistic reaction: it came up to the verge of the subjective. It shows its value fully in the Socratic schools, subsequent to Socrates, in which various tendencies of thought were held together by this one common intuition of the subjective. We are to see its positive characters in our exposition of the views of Socrates himself. It is the mother-thought of all the idealisms, empirical no less than rational, of the history of philosophy. ${ }^{\mathrm{r}}$

${ }^{2}$ Certain recent writers on the history of psychology have seemed singularly blind to this or neglectful of it, although it has been given full recognition by various historians of philosophy. For example, Klemm (Geschichte der Psychologie) is led by his plan of treating only of positive theories, to overlook the Sophists-no doubt because they represented no positive "ism," but merely a point of view. Similarly, Dessoir (Abriss einer Geschichte der Psychologie) passes from the so-called Seelenbiologie, of the early Greek schools, direct to Plato, omitting Socrates as well as the Sophists altogether, to the extreme disadvantage of his treatment of Plato, Aristotle, and the Stoics. This is incomprehensible, even from the simple point of view of the history of ideas. Harms is much nearer the truth (Geschichte der Psychologie), although still too negative. The analogy with the progress of individual thought reinforces the traditional interpretation, which finds in Socrates the transition-by way of the Sophistic reactionto subjectivism and practical idealism: to all that body of doctrine which the subjective point of view underlies. 


\section{Greek Speculation before Socrates 55}

The Sophistic situation reminds us forcibly of the condition of embarrassment in which the growing individual finds himself, as he confronts the puzzle of his own body. On the one hand, the "self" is the body, its principle of organisation and manner of existence are primarily those of external things. But, on the other hand, the personal "self" has the characters of an inner world-the practical, active, characters by which it dominates the body and works effects through it. Like that of the Sophists, the thought of the individual at the corresponding stage of reflection, shows the germs at once of practical idealism and of theoretical positivism. The division into parties shows the two motives actually present in the school, the extreme "humanist" and the more "naturalistic."

It is clear that the significance of the entire Pre-Socratic movement resides in this: it furnished, unconsciously or spontaneously, the dualistic basis upon which the alternatives of later reflection were founded. The "projective" is passing into the "subjective" point of view. The distinction between subjectivism and objectivism, idealism and naturalism, could receive its first and world-famed presentation in Plato and Aristotle, when once Socrates had shown the meaning of the subjective. 


\section{CHAPTER IV}

Greek Speculation, Second Period: Subjectivism

SOCRATES, Plato, and the Minor Socratic Schools.-The significance of "subjectivism" in racial and individual thought alike is this: it isolates the contents of the mind itself from their external references and discloses the possible interpretations that may be placed upon them. To say that the senses deceive, is to say that the interpretation put upon sensation is incorrect or false. To say that knowledge is relative, is to say that our percepts, images, etc., are capable on occasion of varying interpretations. To say that reason is ineffective, is to say, that the beliefs, presuppositions, and processes which are its tools are insufficient. All these misinterpretations turn upon the fact that consciousness possesses data which are taken to be subjective.

To take the subjective point of view is simply to recognise this in some measure; to acknowledge that we must deal first of all with what is 


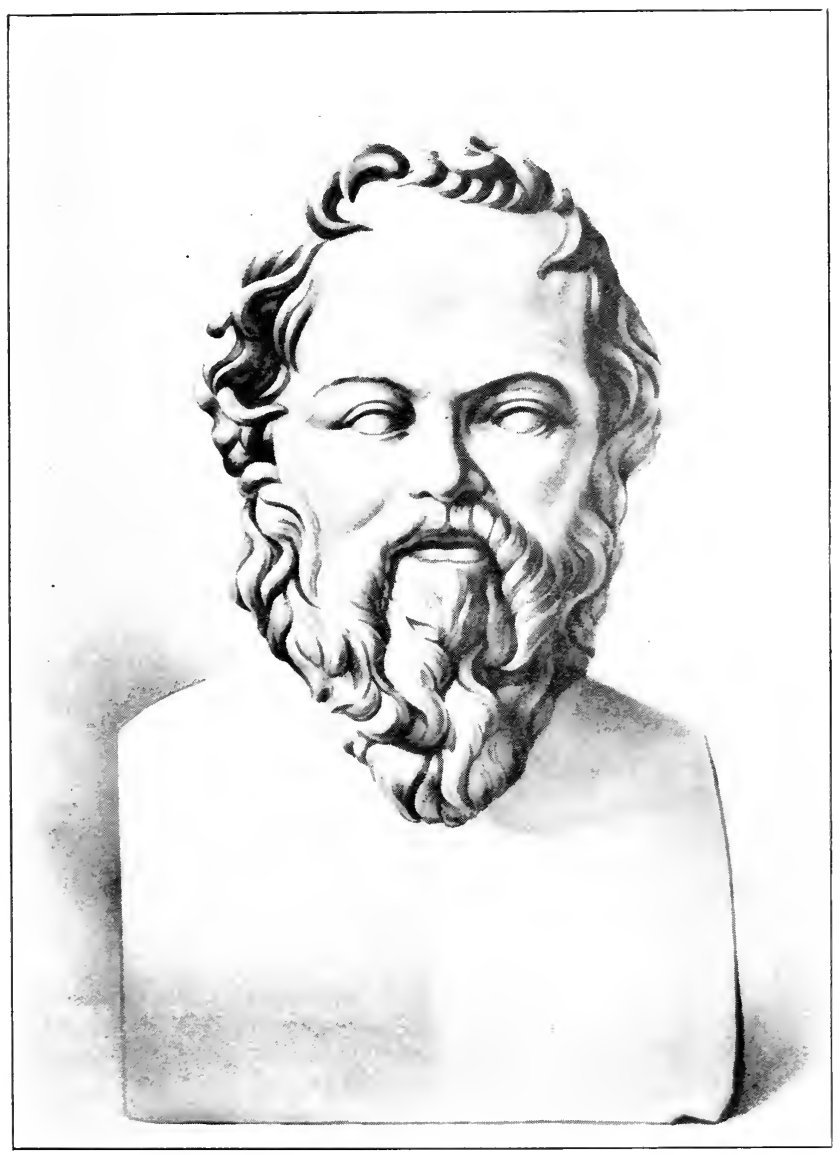

SOCRATES.

(Copyright. Reproduced by kind permission of the Open Court Publishing Co., Chicago, L i....) 

in the mind, with percepts, images, hypotheses, etc., "made up" in consciousness; in short, with "ideas." It recognises that ideas intervene in some sense between the perceiver and the thing perceived; that ideas are the mediating or instrumental term in knowledge.

I. Socrates (469-399 B.C).-The Sophists denied in effect the possibility of passing beyond ideas. To them the interpretations made by the preceding philosophers were all alike false; all that was left for knowledge was the body of ideas itself. Man, the possessor of ideas, was "the measure of all things."

Now in the teaching of Socrates, we find a new sort of interpretation of ideas suggested. Recognising the subjective point of view of the Sophists, Socrates built positively upon it in two different directions, which we may call without violence the "social direction" and the "ethical direction."

First, Socrates opposed the Sophists' individualistic way of employing subjectivism. $\mathrm{He}$ attempted, by his celebrated questioning method (as seen in Plato's dialogue, Protagoras), to bring them to admit a general form of knowledge, a commonly received definition of a thing, which was more reliable and true than mere individual opinion $\left(\delta^{\prime} \sigma^{\prime} \alpha\right)$. The criterion of truth thus comes to be found in collective or common 
acceptance; truth and knowledge are social. It is man in the sense of "humanity," not man the individual, in which the true subjective point of view resides. In this position, the foundation was laid for the theory of general and universal knowledge, ${ }^{\mathrm{I}}$ which was to be developed by Plato, Aristotle, and the Stoics. Socrates said, as Plato reports, that the only thing he knew-being in this wiser than other men, as the Oracle had declared-was that he knew nothing. This is, however, to know something of the meaning, limitations, and value of knowledge itself.

Second, Socrates connected truth with virtue, knowledge with duty. He said that virtue depended upon knowledge in the sense that with adequate knowledge, or insight in to the results of action-called by him "wisdom" ( oop̣! $x$ ) one would never do wrong. This makes action, conduct, depend upon ideas, just as truth does; and carries the subjective point of view into the domain of practice. After this, mere external authority, social constraint, religious sanction, cannot replace the inner light of knowledge.

If all we have is a body of ideas, still this very point of view has results; for it is then our ideas that stand for things, and it is our ideas that

1 This interpretation of Socrates follows that of Zeller, The Philosophy of the Greeks. Cf. also Boutroux, "Socrates" in Historical Studies in Philosophy, Eng. trans. (1912). 


\section{Subjectivism}

guide our actions. Two processes of mediation play through ideas: ideas are the means of attaining both sorts of ends, ends of truth and ends of virtue. ${ }^{\prime}$ In Socrates, the emphasis falls upon the latter sort of mediation, the practical. He establishes the eternal right of virtue; and makes ideas, in the forms of knowledge and truth, means to the ends of practical life. ${ }^{2}$

In this departure, the dualism whose history we are tracing, in the history of theories of the self, takes on a new and valuable phase. It becomes the dualism between the "subjective" and the "external"; between the mind, as a subjective principle and the seat of ideas, and the world of things and of practical interest and values. $^{3}$ In Socrates, this dualism appears in the immature form that it takes on at first also in the individual: it recognises the fallibility of

'In the author's work, Thought and Things, or Genetic Logic, Vol. III, "Interest and Art," it is shown that individual thought and action always proceed by this twofold process of mediation. Cf. also below, Chap. VII, ad fin.

2 This point is made the capital one by Harms, loc. cit., who expounds Socrates' psychology under the heading "Ethical Determinism."

${ }^{3}$ It has not yet become a dualism between "subject and object" as such, in which both terms are set up consciously in experience itself, or within the self. This is achieved only later on, when thought becomes reflective. But it affords the foundation for it, by supplying once for all the refutation of pure externalism either as materialism of nature or as legalism of morals. 
individual perception and personal opinion, and seeks a method of converting the individual's ideas into socially confirmed and general knowledge. It thus saves itself from the pitfalls of sophistic relativity. And again it asserts the correspondence and in'erdependence of knowledge and virtue, with the result of securing the stability of practical interests and values. The child likewise learns to judge for himself, but according to an enlightened social conscience, which comes to replace the ipse dixit of an external authority.

The external term is not a purely objective and neutral system of controlling conditions over against the individual; on the contrary, it is the embodiment of practical values ${ }^{\mathbf{I}}$ over against the social body which is bent on pursuing these values as ends. This is the meaning of the external also to the child, before his prying curiosity develops into consistent reflection. The world is something to conquer and enjoy and something to conform to, rather than something to understand; and the "self" is a body of collective social interests, rather than a personal being of mere desire, individual personal caprice, and private opinion.

I Socrates explicitly added to the intelligent moving principle of Anaxagoras, the idea of "final cause": the intelligence works for the good. See Fouillee, La Philosophie de Socrate, Vol. I, p. 25. 
The result is that, in the school of Socrates, Physics, or the science of objective nature (o'jots of the Pre-Socratics), gives place to Logic and Ethics, pursued by the dialectical method. The gain coming from the human point of view is far from being lost: it is now made positive and lasting.

It is thus that the famous motto of the Socratic school, "Know thyself" ( $\gamma v \tilde{\omega} \theta t$ esxuróv) is to be understood. It is an exhortation to examine man-the social, active, virtuous man-and understand his place in the network of external things and social interests. By such knowledge is virtue advanced; for virtue is taught and learned with the teaching and learning of truth. Freedom is found in intelligent action.

The principal ambiguity that remains-one that reappears in the system of Plato-attaches to the relation of truth to practice, what is known as the "Socratic paradox." Socrates, as we have seen, made the "good" the absolute end, and knowledge the means to it. But the relation thus barely stated may be understood quite differently. It may be taken to mean that virtue is contingent upon knowledge; that the truth of ideas must be established before virtue can be reached or the good conceived. ${ }^{-}$Such a

I It is the virtue (eijpákia), that is founded on knowledge or wisdom that is "teachable," not the virtue (ev่rvхia), which rests on mere opinion. 
turn would give supremacy to the reason, and lead on to systematic intellectualism in the theory of morals. ${ }^{-}$The empirical question involved-that of the relation between cognition and will--is one of modern psychology. Its answer in later thought will concern us further on.

Although put to death for "impiety," Socrates held to the existence of a supreme God. His belief in the spirits of the earlier theogonies is attested by his claim that he himself was guided by the prohibitions and restraint of a "demon" which, however, never guided him positively.

II. Plato.-In the philosophy of Plato (427347 B.C.), the factors of earlier thought have

${ }^{r}$ Of course, Socrates could not foresee the use later speculation was to make of his intuitions. And it is worth saying, though it is not new, that the "Socrates" of Plato's Dialogues (the Menon especially) is, in this matter as in others, a Platonic Socrates. However well intended by the author, we must suppose Socrates' opinions to have been developed somewhat in the direction of Plato's. On the matter before us, the following is the decision of Fouillée: "Socrates was not exclusively moralist, as the reading of Xenophon would lead us to believe, nor as much of a metaphysician as Plato represents him. His proper point of view is that of the unity of ethics and metaphysics in the notion, at once practical and speculative, of final cause" (Fouillée, loc. cit., Vol. I, p. 34). In his opinion also Socrates is an ethical determinist, assuming that he discarded free-will (a question, however, which he did not discuss.) 


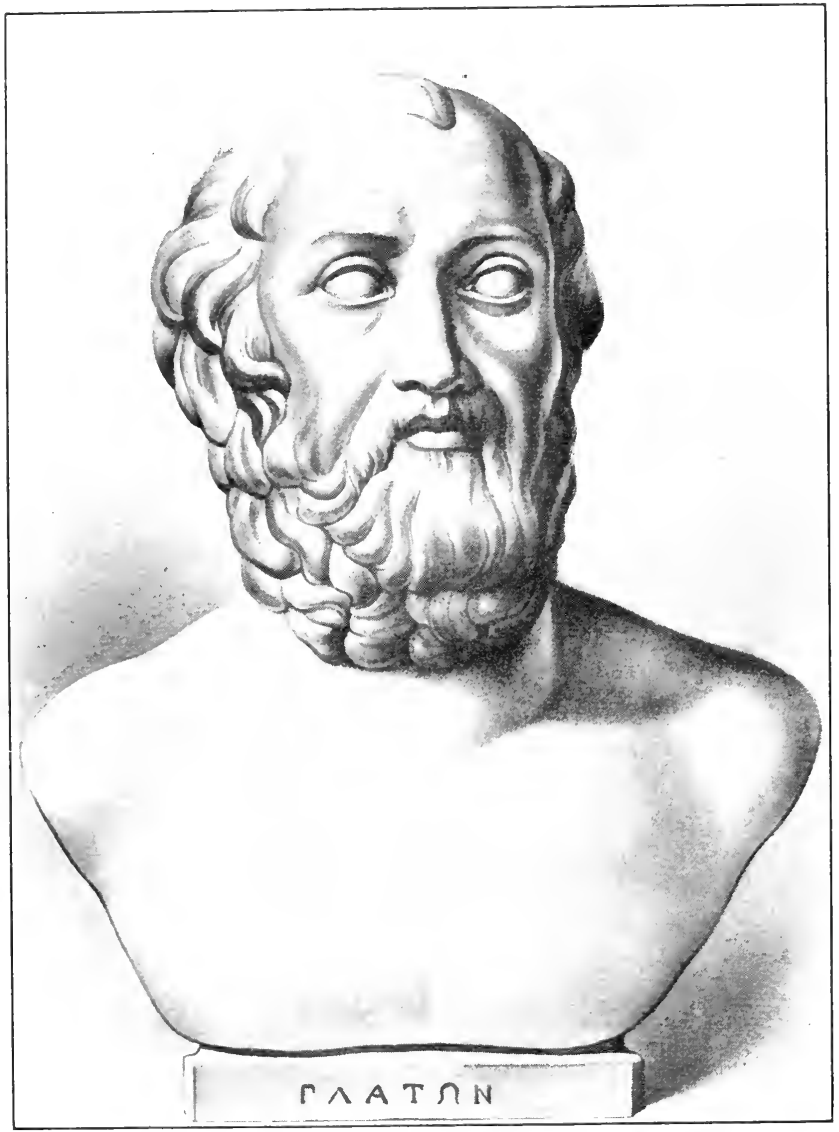

Plato.

(Copyright. Reproduced by kind permission of the Open Court Publishing Co., Chicago, U.S.A.) 

explicit development. We will indicate only those aspects which bear upon the problem of psychology.

Plato's thought centres in the celebrated "theory of ideas." Its meaning in brief is that ideas or concepts are not merely subjective states of mind, but absolute realities existing in themselves. Every actual thing in nature has its absolute prototype or model in "idea." What degree of reality things have comes only from the presence of this prototype, of which the thing is a mere "shadow." The ideas constitute a hierarchy or ascending series, the supreme idea being God or the Good. The idea of the Good must be the highest idea, and it must be divine.

In this theory there is a further advance in the direction of the Socratic teaching. The starting-point is the idea, but it is now not only not an individual state, but also not merely a subjective thing; its meaning is what is important, its existence as reality per se. This is the beginning of a typical form of rationalism, one that considers the mediating term, the idea, not as the instrument of knowledge, but as itself revealing the real. A further thing-a second real something-reached through the idea, is given up: such apparent realities are mere shadows, reflections, pseudo-ideas. In the intuition of the idea, the absolute itself is directly apprehended. 
By this step, the dualism of the earlier philosophy is carried forward and enriched. The "spirit" of Anaxagoras and the formal "number" of Pythagoras are given the quality of the idea. The absolute is enriched by the gain accruing from the Socratic subjectivism; it becomes a rational principle. Furthermore, its highest embodiment in the idea of God makes it, in the final interpretation, something spiritual.

Again the ethical significance of the Socratic point of view is not lost in the rationalism of Plato. To Socrates, all things exist for the sake of the Good; ideas are means of attaining virtue; all cause in nature is final cause, a process working to a desirable end. Plato is true to his master here; and in his doctrine of ideas he justifies the thought by a metaphysics. Instead of ' being a mere belief, a pious hope, the absolute Good is really present in the supreme idea. The rational principle culminates in God, the supreme reason, and the ethical principle in the Good, the supreme end. These two are one: the idea of the Good is God.

The process of mediation involved in the Socratic method-the mediation of ends or "goods" by concepts-is therefore not superseded in the Platonic process of mediation of realities by ideas. Both are recognised in their culmination, in the final synthesis of God and the Good. In this the motives of individual 
thought are again exhibited in their integrity. The individual finds that truth is reached through ideas, and also that ideas lead to satisfactions; both processes of mediation hold good. He does not find it necessary to deny one of them in making use of the other. It is only when his further reflection leads him to inquire into it, that he finds that he himself, following social leading, has already united the two results in a further synthesis and embodiment in personal form. Father, priest, God, each may become in turn the being in whom knowledge and goodness are alike and together realised. The hero is at once the wise man and the good man; God is the great Hero, the eternal Good. We are all naturally to this degree Platonic in our definition of God.

In this result, too, the "ejective" process in the growth of reflection, individual and racial alike, reaches its full statement. The rationalethical postulate of God, in Plato, follows upon the animistic and anthropomorphic postulates of early religious mysticism. It secures deliberately, in terms of reflection, what the earlier movements secured spontaneously, in terms of ejection: the presence of personality in the divine nature.

Psychologically, this is of great interest, because it shows us the gradual feeling of the hidden motives of dualistic thought. Both vol. $1-5$ 
the processes of mediation, each working through ideas, set the inner life over against the outer; the world of reason, order, and the good, over against that of appearance, plurality, disorder, and imperfection. So far we have dwelt upon Plato's theory as it affects the first of the opposed terms of the dualism; we will now look at his treatment of the second.

In the human person, according to Plato, reason or the idea is involved in matter, or the body, through the presence of the soul. The soul as common principle partakes of the nature of both. It has an immortal or rational part, coming from God; and also a mortal part ('s $\pi$ $\theta$ jur $-6 x^{\prime}$ ' $)$, the seat of appetite and sensation, belonging to the body. Lying between these and making their interaction possible, there is a third part $(\theta$ uros s), by means of which reason conquers desire. Plants have the lowest part; animals the two lower, but not reason, which is exclusively human. In man, the head, breast, and abdomen are the respective seats of the three.

The rational soul pre-existed and also survives the body. It is immortal, gradually freeing itself from its non-rational parts through transmigration into new lives separated from one another by periods-each of a thousand yearsof the penalties of purgatory.: Nature shows

s For the worst offenders, being everlasting, it is no longer "purgatory," but "hell." 
an upward progress, whose end is represented by man (but not by woman!), since in man the rationality is achieved in which the absolute good is freed from the corruptions of matter. Matter $\left(\left\langle\lambda \gamma_{1}\right)\right.$ is not a positive substantial principle, but one of limitation and confinement. It is the "matrix," the "nurse," the "mother," of the generation of reason. The world as a whole is a living being ( $\zeta \tilde{\omega} \sigma \nu)$ of whose life living organisms partake. The world-soul takes form in individual souls. In all this, we see the return to a mystic or psychosophic point of view. The objective loses its exact content, reverting from the naturalism of Democritus back to the hylozoism of the Ionics.

The service of Plato, accordingly, in the doctrine of ideas, consists in having developed the subjectivism of Socrates and in having rationalised the spiritualism of Anaxagoras; not certainly in having clarified the concept of nature or in having hastened the advent of scientific method. Psychology, understood in the empirical sense, remains a part of "physics," which treats of the shadow-world.

In discussing the reason, Plato held that the knowledge awakened in the mind-all learning and research-comes by a "reminiscence"

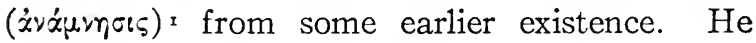

'This doctrine is found in Plato's exposition of Socrates' views in the Menon. 
formulated the two laws of association, known as "resemblance" and "contiguity," to explain the play of ideas.

Finally, we should remark that two great directions are represented in Plato's views. In the first place, he started out from Socrates' instrumental theory of knowledge; concepts are the instruments and means of attaining practical and moral ends. But in making ideas themselves realities, Plato goes over to a more rationalistic point of view. Instrumentalism passes into absolutism. The point of unity of the two is, as we have already noted, the identification of the highest idea or God with the absolute Good. The question arises, then, by what mental process - whether idea, feeling, intuition, - this identification is effected.

We here reach the apex of this extraordinary structure of thought. While in his later life (in the Timaus), Plato emphasised rationalism by making existence the outcome of ideas of identity and difference - the soul having existence in this sense-still his characteristic view is more mystical. Plato the poet, the artist, was as profound in sensibility as Plato the philosopher was in thought. The divine reason in man, he says, responds to the divine good in God; by love and contemplation the soul realises the union of wisdom and goodness in God, and attains its own proper immortality. Plato's 


\section{Subjectivism}

doctrine of divine love ("̈p $\omega \varsigma$ ), exercised by immediate contemplation of God, is a recognition of the synthesis of knowledge and value, of thought and practice, in a higher immediacy which is contemplative and æsthetic-"pancalistic" -in character. ${ }^{\mathrm{r}}$

It makes the æsthetic the fundamental reconciling category. This is the first appearance in the history of philosophy of another movement which clearly appears at the same relative place in normal individual reflection. The individual presses the two modes of mediation, cognitive and active, each to its limit; and at the limit, each of them by an outgo of the imagination postulates its own ideal. Then, overcoming this final opposition, the two ideals become fused together in the one immediate and ineffable object of contemplation. The æsthetic mode of apprehension is thus called into play; it reaches the reconciliation of the terms of the dualism of thought and action; its object is one of beauty, one to love and adore. ${ }^{2}$

r See below, Chap. II of Vol II, on Kant's Pancalism. Plato, however, proscribed most forms of art from his ideal Republic, holding that they had too "softening" an effect in education.

${ }^{2}$ An analogous interpretation of Plato is presented, with psychological insight and great learning, in Prof. J. A. Stewart's book, Plato's Doctrine of Ideas. He uses, as I do here, the terms "instrumental" and "æsthetic" for the two Platonic points of view. For the analogy with 
It was this form of Platonism, not the developed rationalism of Aristotle, that first gained currency, through the Neo-Platonists of Alexandria, and held its own for more than two centuries.

The child's preparation for the enjoyment of beauty undoubtedly involves the play-functions, as current æsthetic theory admits. By these functions mental material becomes detached and disposable for "semblant" and imaginative uses. Something analogous is seen in the course of Greek reflection in the sophistic "play" of ideas.

In the Minor Socratic Schools, the "Megarics" (Euclid of Megara), the "Cyrenaics" (Aristippus), and the "Cynics" (Antisthenes, Diogenes), the Socratic leading was dominant, with little further result for psychology. The beginning of "hedonism" appears in Aristippus, who, on this point, prepared the way for the Epicureans. He taught that pleasure was positive, not the mere removal of pain; also that pleasure, defined in sensuous terms, constituted the good and afforded the criterion of truth. Virtue was prudential in character. In the Cynics, we

the individual's process, one may note the suggestion made in the author's article, "Sketch of the History of Psychology," Psychological Review, May, 1905 (developed in University lectures). See also W. D. Furry, The IEsthetic Experience (1908). 


\section{Subjectivism}

have similar suggestions of the philosophical positions reached later on by the Stoics; nature and fate were the great realities, to which man was to subject himself with simplicity and without pretence. 


\section{CHAPTER V}

The Third Period of Greek SpeculationOBJectivisM

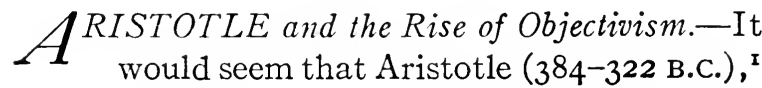
without doubt the greatest scientific man, if not also the greatest speculative genius, that ever lived, arose to restore the empirical tradition to philosophy after the plunge into absolutism. The time was ripe for the foundation of empirical psychology, and following his scientific instinct, he founded it. But the time was not ripe for its entire philosophical justification, and he did not justify it. He had the right to found formal logic, and he took advantage of the right. His achievements in natural science, politics, æsthetics, and ethics are also those of a man of the highest constructive genius.

These remarks follow from the one statement that Aristotle developed both the empiricism of method of Socrates and the rationalistic logic that Plato inherited in the Ionic and Pythago-

${ }^{x}$ Called the Stagirite from his birthplace, Stageira, a Greek colony in Thrace. 


\section{Objectivism}

rean tradition. Confining ourselves to the psychological bearings of his views, we will look at his doctrine from both sides, taking the metaphysical first.

Aristotle distinguished four sorts of "cause," as working together in things: "efficient," "formal," "final," and "material" cause. Of these, three fell together on the side of form

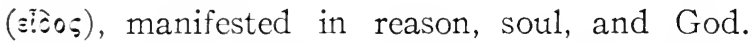
The fourth, the material cause, is matter $\left(" j \lambda \eta_{i}\right)$. This is Aristotle's interpretation of dualism. Aristotle declares that final cause was the relatively new conception which had been clearly distinguished before him only by Anaxagoras.

But matter is not an independent principle: it exists only in connection with form and design. It is a limitation, a relative negation. The only independent absolute principle is God, who is, as in the Platonic teaching, both Reason and the Good.

With such a metaphysics, there is no positive justification of science, psychological or other. Objective nature is teleological, an incorporation of reason, which gives it its form, movement, and final outcome. Life is a semi-rational teleological principle, working to an end-a vitalistic conception. All form in nature is the product of a formative reason. Natural phenomena are not purely quantitative; formal distinctions are qualitative. 
The objective world is thus given its right to be; but it is a world in which reason is immanent. There are two great modes of reason, considered as cause, in the world: a cause is either a potency

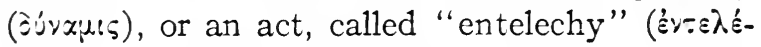

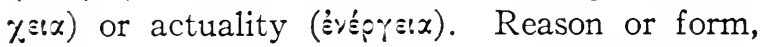
when not actual, slumbers as a potentiality in nature. Pure reason or God is pure actuality; matter is pure potentiality. As such God merely exists in eternal self-contemplation, apart from the world. The heavenly bodies are made of ether (not matter like that of the four elements) and have spirits; they are moved by love, directed toward God. In this we have a concrete rendering of the ideas and divine love of Plato.

On this conception, "physics," which deals with phenomenal appearances, including psychology, is contrasted with the theory of causes, "first things," or "metaphysics."

This philosophical conception so dominates Aristotle's mind that he practically abandons, in theory, the subjective point of view. In his view of the soul, he goes over to a biological conception, which is, however, not that of evolution. Natural species, like the types of Plato, are immutable." The soul is the "first en-

I The subjects that followed "after physics" ( $\tau \dot{\alpha} \mu \epsilon \tau \grave{\alpha}$ $\tau \grave{a} \phi v \sigma(\kappa a)$ in the collection of Aristotle's writings made by Andronicus.

${ }^{2}$ Animal forms show a gradation up to man, but they 


\section{Objectivism}

telechy" or formal cause of the body; in essence it is akin to ether. It embodies also the efficient and final causal principles. Man, in the masculine gender, alone realises the end of nature. Psychology thus fused with biology extends to plants and animals and so becomes a comparative science. The plants have nutritive and reproductive souls; they propagate their form. Animals have besides, the sentient and moving soul, which is endowed with impulse, feeling, and the faculty of imaging. In man, finally, the thinking or rational soul is present. This is implanted in the person before birth from without; and at death it goes back to its source, the divine reason, where it continues in eternal but impersonal form. It is two-fold in its nature in man, partaking both of divine reason and of the sensitive soul; it is both active and passive

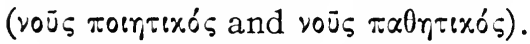

In the theory of the relation of these souls to one another, Aristotle advances to a genetic and strictly modern point of view. They are not separate "parts," having different local seats in the body, as Plato taught, but functions of the one developing principle. The higher is developed from and includes the lower.

do not represent an actual evolution, as the Ionic philosophers had declared, but incomplete or abortive efforts of nature, which aims at producing man in whom the active reason appears. 
In all this, it is evident that while the objective point of view is maintained, still the doctrine is not the result of a searching of consciousness; nor does it employ a strictly empirical method. It does not isolate the sphere of mind as one of conscious fact, distinct from that of the physical. The results are on the same level for mind, life, and physics in the narrower sense; they are deduced from the immanental conception of nature as a whole. So far Aristotle the metaphysician.

But Aristotle the scientific observer is still to be heard from. It is clear that psychological facts may be observed, just as other facts may be, even in the absence of any clear distinction as to the presence or absence of consciousness. Aristotle set himself to investigate the functions of the soul, looking upon it as the biological principle of form in nature. ${ }^{x}$ In this sense, as using an objective method of observation, and as making important and lasting discoveries, he is properly to be described as the pioneer psychologist. $^{2}$

${ }^{I}$ In this he anticipated the modern, more explicit attempt to objectivise the mental sphere while retaining the essentially subjective character of its content. It appears later on in Comte's attempt to do justice to psychological facts in connection with social, and in recent definitions of animal psychology as the "science of animal behaviour," both matters touched upon later on.

2Aristotle's psychological treatises are De Anima 
We may now enumerate the most celebrated psychological doctrines of Aristotle, those in which his permanent influence has shown itself.

$\mathrm{He}$ divided the mental functions or faculties into two classes, the "cognitive powers" (those of knowledge and reason), and the orectic or "motive powers" (those of feeling, desire, and action). This division survived until the threefold Kantian classification of intellect, feeling, and will came in. ${ }^{x}$

Aristotle's theory of knowledge extended from sense-perception at the bottom of the scale to the active reason at the top. There are three stages: sense-perception ( $\alpha(\sigma \theta \eta \sigma \iota \varsigma)$, imagination

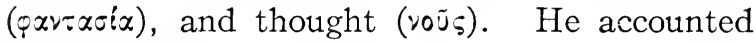
for perception by supposing harmony or correspondence between the sense-function and the

$(\pi \epsilon \rho i \psi v \chi \hat{\eta} s)$ and Parva Naturalia. A recent work giving a translation into English, with full Introduction and Bibliography, is by Prof. W. A. Hammond, it is entitled Aristotle's Psychology (1902).

${ }^{2}$ In his general psycho-physical conception, Aristotle is startlingly modern, save, of course, in the actual results reached. He gives detailed and conclusive reasons for locating the soul not in the head but in the heart, which, as he discovered, was the centre of the vascular system; for considering heat the material substratum of life and mind; for regarding the veno-arterial system (with the blood) as the channel of communication of sense and motion. But for our knowledge of nerve and brain, we should consider his argument a model of inductive reasoning, as indeed it was taken to be for generations. 
stimulating external conditions-as, for example, between vision and the illuminated object-the harmony consisting in the form common to the two, and its favourable condition being a mean between extremes of stimulation. The general function of sensation is to take the form of the object, without the matter, over into the mind. He distinguished five senses, correlating them with the physical elements. Colours were compounds of black and white, the original qualities of light. Similarly, all tastes were combinations of sweet and bitter.

For the co-ordination of the various sensations and their formation into true perceptions, Aristotle supposed a "common sense," located in the heart. It is also by the common sense that images arise and become memories, dreams, and fancies. These images in their revival follow three laws of association: "contiguity," "resemblance," and "contrast." It is in the common sense, moreover, that the judgment of things as true or false takes place, and the common "sensible qualities"-motion, number, shape, size-are attributed to things. The common sense gives unity to consciousness itself.

Only man has active recollection and constructive imagination (as employed in art). The imaging function is necessary to thought as sensation is to imagination. By the productive 


\section{Objectivism}

imagination the necessary schemata are supplied to the reason.

In the creative or higher reason, Aristotle finds a principle which brings rational certitude into the empirical matter of the common sense. As adding an element of absolute form, it is "active"; as having commerce with empirical data it is "passive." The interpretation, however, of the active as contrasted with the passive reason, is in dispute. ${ }^{\prime}$

In the investigation of thought proper, the entire body of formal or "Aristotelian" logic was worked out. The theory of syllogistic inference sprang full-formed from the brain of Aristotle. He even suggested, in his treatment of the "practical syllogism," that the laws of conduct might be thrown into similar form. ${ }^{2}$

In his theory of the "categories," of which he finds ten, Aristotle enumerates the different modes of predication possible about the same thing or subject.

Similar fruitfulness attached to the investigation of the motive powers. All perceptions,

'See Hammond's account of the different views (Aristotle's Psychology, Introduction). No doubt the best commentary is that afforded by the theoretical developments which followed upon Aristotle's incomplete statements.

2Eth. Nic. II 47 b, I8. The "Nichomachean ethics" is thought to be a treatise on morals addressed by Aristotle to Nichomachus, his son. 
said Aristotle, are accompanied by pleasure and pain, which also characterise emotion, and issue in impulse and desire. Pleasure and pain are, in general, signs, respectively, of advanced and hindered life. Emotion is a mixture of pleasure and pain, either actual or suggested by percepts and ideas. On the basis of emotional differences, Aristotle founded differences of temperament. These remarkable positions remained the exclusive doctrines in the domain of feeling until modern times; and they are integral elements in the scientific conceptions of to-day.

As to the active and voluntary life, the same rare genius displays itself. Impulse and appetite are stimulated by pleasure and pain; emotion prompts to action. But along with this impulsive spontaneous action, there is deliberate will, which arises in desire. Desire is awakened by ideas or knowledge. There is a hierarchy of active motives and ends, as of intellectual states; stages of desire, will, and rational choice depend respectively upon perceptions, empirical knowledge, and rational insight. This introduces a certain rationalism into the theory of the practical reason and reminds us of Socrates' theory of the relation of conduct to knowledge. The rational will is free; but the principle of will in general extends into all organic nature in the form of impulse or potentiality. It is somewhat ana- 
logous to the "conatus" of Spinoza and the "blind will to live" of Schopenhauer.

In morals the doctrine of the "mean"virtue being the mean or moderate exercise of a power tending to self-realisation-had its influence on the Stoics and Epicureans.

These principles of Psychology and Logic were carried by Aristotle into the domains of "Ethics," "Politics," "Esthetics," and "Rhetoric" with a success that has made him one of the greatest authorities in all these subjects for all time. In his discussion of art, developed in the Poetics, he holds that the artistic imagination is imitative ( $\mu\left(\mu, \gamma_{0} s s\right)$, producing a purified or idealised picture of the real. Art is always concerned with

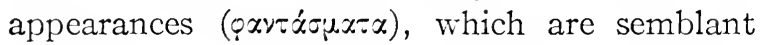
of the real. The drama serves to afford an outlet for the emotions of pity and fear-a function by which the soul is purged and ennobled. In accordance with this view, the universe is a work of art, a whole in which an ideal is presented in sensible form. It is present eternally to the contemplation of God, to whom it responds with love through the spirit which is in it. In this we see the tendencies which were referred to in the case of Plato as being "pancalistic," losing something of their mysticism and taking on more articulate form.

Summing up, we may say of Aristotle that his philosophical theory did not advance or vol. $\mathrm{I}-6$ 
clarify the dualism of mind and body; but that this dualism was re-cast by him in the distinction of "matter and form." This obscured the subjective point of view. It placed emphasis upon the objective to such an extent that mental phenomena, considered as vital form, became matter for objective observation along with physical phenomena. In this way, psychology was treated as a branch of natural history or "physics"; and as such it took an enormous stride forward.

Incidentally, also, the doctrine of the soul as form led Aristotle to combat theories of a spiritistic and "psychosophic" character, such as metempsychosis and pre-natal reminiscence. This was an important gain to the naturalistic point of view. But Aristotle's vitalism prevented its issuing in a complete scientific naturalism. ${ }^{x}$

I This has remained a hindrance in the development of the subject-matter of positive science. In the growth of the modern sciences, psychology has been about the last to attain the full naturalistic point of view. The physical sciences achieved it earliest, that is, the sciences of the purely objective and external. But they were long embarrassed by the intrusion of an ill-defined and mystical postulate of soul or mind or reason, made the explaining principle even in the domain proper to science. It was to be expected that physical, like mental science, would be able to define its subject-matter clearly only after the substantive distinction between mind and matter was 


\section{Objectivism}

But, as we are to see, of the two sides of Aristotle's doctrine the formal, embodied in the new logic, was to gain the ascendency. With this weapon the Patristics, Scholastics, Casuists, Logicists, and deductive reasoners of every sort hit about them with deadly effect, having their way for centuries, while natural science slumbered under the pall of the Middle Ages.

\section{The Post-Aristotelian Schools:: The Epi-} cureans.-Epicurus $(342-27$ O B.C. $)$ reproduced tendencies current before Aristotle, but united them in a more consistent philosophy. The atomism of Democritus, says Epicurus, gives the proper account of the soul; its faculties are built up upon sensation, its desire is for pleasure, and it dies with the death of the body. For psychology, the life of sensation and that of activity in the pursuit of pleasure, sum up the teachings of the school. Sensation is produced by images passing from the object through the air and

achieved and the latter was defined in terms of extension. Only later still-and not completely yet-have the biological sciences freed themselves from this sort of intrusion; seen in animism, vitalism, and teleology in its various forms. As to psychology, the distinction between naturalism of content and method, and spiritualism of principle finds difficulty in maintaining itself to-day.

r An able account of the period is to be found in Caird, The Development of Theology in the Greek Philosophers, II, Lect. XV. 
striking upon the sense organ. A doctrine of freedom, in the sense of caprice, is based upon the postulate of accidental deviations in the course of the falling atoms. This is the first appearance of articulate sensationalism in psychology, and as in its later appearances, in the French Encyclopxdists, for example, it is associated with a materialistic metaphysics. It unites the subjective relativity of the Sophists with the physical ontology of the Atomists. ${ }^{x}$

The Stoics.-Under this heading (derived from the word crix, a porch) a great variety of tendencies is gathered together and a group of thinkers included. Zeno "the Stoic" (336-264 B.C.) is the founder and the most representative Greek of the group, which includes Greek and Roman literary men, as well as professed philosophers. Chrysippus (cir. 280-207 B.C.) was the logician. Seneca, Epictetus, and the Emperor Marcus Aurelius were prominent Roman Stoics.

The Stoic movement was a return to sober and practical understanding, after the rogue of high theories of the reason. Knowledge in the interest of practical life; prudence guided by information; freedom as expression of personality in a world rules by law and subject to fate; social

I The great poem, De Natura Rerum, of the Roman poet Lucretius, presents in not too faithful form the philosophy of Epicurus. 


\section{Objectivism}

obligation and calm enjoyment over against capricious individual pleasure; - such were the Stoic counsels of moderation, justified here and there by personal and eclectic philosophical considerations. ${ }^{x}$ Conscientiousness toward man and resignation toward fate are its watchwords. In the Roman group they were embodied in lofty maxims of friendship, duty, and humanity. ${ }^{2}$

Little that is psychologically noteworthyas distinct from the practically moral-appears in it; and what does appear is suggested rather than explicitly stated. Zeno contended, against both Plato and Aristotle, that the soul was one, a unit function in whose activity all the parts and powers of sense and reason were included. The conception of common sense, considered as a centre of organisation and unity, was expanded into a doctrine of "consciousness," which was of the nature of knowledge-literally a "knowing together." Feeling and will were aspects of knowledge, while error and misfortune were due to its abuse or misdirection. Sensation is accepted or agreed to by the understanding.

The soul was corporeal, fire-like, and ethereal,

${ }^{2}$ Cf. Caird, loc. cit., Lect. XVII, for an account of the general social bearings of the Stoic movement.

${ }^{2}$ Undoubtedly the loftiest and purest of moral codes based on humanity; it yields only to the Christian ethics of love, expounded so soon after in the "Sermon on the Mount." 


\section{History of Psychology}

as was also the world-soul or God. The world developed by laws, showing "necessity" ( $\dot{\alpha} \dot{\alpha} \gamma \times \eta)$, the Epicurean "chance" ( $\left.\tau^{\prime} \nsucc \eta\right)$ being excluded; it embodied reason $(\lambda \circ$ yos$) \mathrm{r}$ and showed divine Providence or design. There was a cycle of creative periods; and the soul had only the duration of one of them.

On the whole, the Stoics vindicated the Socratic practical wisdom in real life: a tempered and humane enjoyment and a just resignation. Their dualism was that which appears between the values of experience and life on the one hand, and a colourless but necessary world-order on the other. They undoubtedly gave a more positive and lasting meaning to the subjective life, the inner seat of affective and active processes, sharing this with the Epicureans. And in the doctrine of the unity of common sense or knowledge, they transferred speculative interest to the self as the bearer of consciousness and the centre of values. This was the transition of view-point required to give to psychology its restricted sphere and to justify its place as a science of inner or conscious phenomena, after the undue objectivation of the mental by Aristotle. With the clarification of the inner sphere thus

I The term "logos" was used before this by Anaxagoras in connection with the principle of reason. It passed through Stoicism and Alexandrianism into Christian theology. 


\section{Objectivism}

brought about, the analogy with the "subjective" stage in the individual's self-apprehension goes forward. Racial reflection, like that of the individual-when once the thought of self as the centre of conscious processes is achievednever again loses this vantage-ground. Consciousness, the background of the Sophists' scepticism, the theatre of Socrates' dialectic, the object of Aristotle's research, and the postulate of occultism and theological mysticism, is on the point of becoming the presupposition of speculative thought. It had to wait, however, to come actually and fully into its own, for the emancipation of reflection, after the period of the domination of the Church.

III. The Greek Mystics, Neo-Platonism.The elements of mystic contemplation found in Plato became explicit in the Greek Mystics. The influence of Oriental thought, notably Jewish, united with this in a revolt against the exclusive pretensions of the reason as organ of apprehension of the world and God. For this the new intuition of the conscious person, the embodiment of the soul, thrown into relief by the Stoics, and soon to be explicitly demonstrated in an anti-materialistic sense by Plotinus, supplied the needed vehicle. It was furthered by the sceptical criticism of the members of the New Academy (e. g., Carneades, cir. 2 I 3 B.c.), who 
developed the theory of relativity of Aristippus and the Sophists. ${ }^{\prime}$

The world issues from God by a series of emanations or outpourings; by these he is manifested, without loss or impoverishment to himself. In concentric circles, the Divine becomes dilute, its perfections are impaired in the world-soul and in angels, demons, and men. This is the "fall," the descent of man. The ascent is through love and ecstasy, by which the soul rises through a series of embodiments, gains the stars, and finally reaches again its divine source.

In Philo of Alexandria, called Philo Judæus or "the Jew" (cir. 30 B.C.-A.D. 40), the explicit union of Jewish theology with Platonic idealism is effected. In the series of personal beings interposed by Philo between God and man is the "Word of God"; a doctrine in which the "Logos" of the Stoics becomes the "Word" or "first begotten Son" of the Gospel of St. John. Philo makes the conception of personality fundamental, and depicts the world as the imperfect form in which the perfect reveals itself. In these vital points, he leads the Alexandrian movement.

In the Neo-Platonist group proper, or "Alexandrians," Plotinus (A.D. 205-270) is the com-

I To these more intrinsic factors should be added the recrudescence of psychosophy and superstition favoured by the disturbed political and social conditions after the Macedonian invasion. 
manding figure. ${ }^{\mathrm{I}}$ In his doctrines, the motives of speculation are clearer, since they are more essentially Greek. The emanation theory becomes a philosophy of creation which, as Harms points out, leaves aside the principles of causation and finality, both essential in the rational thought of the time. The world-movement is depicted as one simply of occurrence, happening, the embodiment of a rational principle. God reveals himself in successive pulsations, proceeding from his inner nature; instead of in a hierarchy of ideas, originating in thought. There is a hierarchy of quasi-personal existences, apprehended by the soul as in nature one with itself. The different "souls" of Plato and "mental powers" of Aristotle indicate stages of degradation of the divine person, down to the animal and reproductive soul, and finally to matter itself.

Plotinus argued directly for the spirituality of the soul. His two main positions were, first, that the animate organism could not arise out of the inanimate particles by combination; and second, that continued personal identity is proved by memory. The latter position probably suggested the doctrine of "memoria" of St. Augustine, mentioned below.

To Plotinus, God is a mind, without body or

I Assigned to the school of Alexandria, though born in Egypt out of that city, and teaching, after about A.D. 245, in Rome. 
self, in which all ideas arise. $\mathrm{He}$ is the first stage in the manifestation of pure identity, or being, or the One, ${ }^{2}$ conceived very much in the sense of the substance of Spinoza. After Mind comes the world-soul which is in turn present in all individual souls. These last are conscious and personal. The individual arises, by a series of intuitions of the successive stages or embodiments, to a state of union with the impersonal and absolute One. This is a state of ecstatic love and contemplation.

The movement is mystic in two senses, both of which are important for the history of the development of dualism. In the first place, God, ${ }^{2}$ and with him all concrete reality, is in essence a personal presence, not a rational idea. The movements in the real are likewise inherent and immanent, simply presented as given facts; observed, not accounted for on logical grounds. The dualism, therefore, of objective things and personal soul (whether rational, sensitive, spiritual, or whatever it be) is abolished. Its terms are reconciled through the intuition of unity in their divine source.

${ }^{x}$ According to Boutroux (Historical Studies in Philosophy, Eng. trans., p. 157), Plotinus himself connected his transcendent One with the Absolute of Aristotle, which existed apart, in pure self-contemplation.

${ }^{2}$ Or, with Plotinus, the next lower being, the "worldsoul." 
Again, the same appears in the method of apprehension of God or the real. It is by an act of contemplation or direct intuition that the human soul vindicates its oneness with the divine. The will goes out in ecstasy, the heart in love; the will subsides in self-repression, the heart in a trance-like calm. The divine presence, not revealed to thought or attained by effort, is taken up in feeling, by a movement of personal absorption. Here we see the legitimate development of Platonic "love," freed from its rational presuppositions.

The "ejective" process, the reading of God and the world in terms of personality, reaches here its culmination. It is the form of panpsychism which succeeds to the heritage of Ionic hylozoism and the Platonic "idea." With this the motives of reconciliation of dualism appear in personal intuition, contemplation, emotional and æsthetic realisation. In the earlier doctrines, ${ }^{\mathrm{I}}$ the true and the good were

I The Indian systems, which we have no space to describe, present analogies with Neo-Platonism. They give an exhibition of thought which is in principle intuitive rather than reflective, contemplative rather than logical. We can easily see, on comparing Oriental with Occidental civilisations, which of the two types of thought has proved fruitful for science, including psychology. For a comprehensive exposition of Oriental systems, see J. E. Carpenter, article "Oriental Philosophy and Religion," in the Dictionary of Philosophy and Psychology of the present 
reached indirectly, mediated by ideas: here they are apprehended immediately and directly in an act of communion with God.

writer. Harms (loc. cit., pp. I93 f.) makes an interesting comparison of Oriental and Greek dualisms with that of Descartes. 


\section{PART III}

\section{THE RIPENING OF DUALISM}

\section{CHAPTER VI}

The Patristics, Scholastics, and Arabians; The Mystical Reaction

I. Christian and Patristic Psychology. $\mathrm{I}$-The motive of dualism, fundamentally present in experience, was not permanently overcome by the mysticism of Alexandria. The voice of reason, no less than the demands of conduct, insisted upon the distinction between the self and the world. The achievement of the consciousness of personality only served to reinstate this distinction in more mature form. This appeared in the spiritual and logical dualisms that dominated Patristic and Scholastic thought, and culminated in the doctrine of "substances" of Descartes.

${ }^{x}$ See the well-documented article on Patristic Philosophy by E. T. Shanahan in the writer's Dictionary of Philosopliy and Psychology. 
The point of view represented by the Founder of Christianity was ethical rather than psychological. It placed in a new light, however, certain essential truths of the subjective life. The "Sermon on the Mount," the most sublime of moral discourses, places personal responsibility in motive, intention, rather than in obedience to authority or in explicit action; and so bases morals upon the innermost springs of conduct. It is a sharp rebuke to externalism and legalism.

New doctrines of justice and love are also taught: the justice of the "golden rule," and the love that turns the other cheek. The personal virtues of humility, charity, resignation, of the Stoic Moralists receive a new interpretation in the principle "out of the heart are the issues of life." In this practical subjectivism, Jesus may rightly be looked upon as a new and more enlightened Socrates.

The general theory of personality also had its advancement. The doctrine of the Fatherhood of God gave new force to that of the brotherhood of man. This figure of speech was employed by Jesus himself-the figure by which a most intimate social bond was symbolised between men and between man and God. A personal individualism, tempered and sustained by universal moral justice and love-as in the answer to the question, "Who is my neighbour?" in the 


\section{Patristics, Scholastics, and Arabians 95}

Parable - is the Christian substitute both for the naive collectivism of early Greek thought and for the more conscious solidarity of Roman nationalism and civic pride.

The spiritualism of the Church Fathers was a view of the soul worked out in the interest of Christian eschatology. Developed into a message of salvation, the theory of Christianity involved statements as to the nature, origin, and destiny of the individual soul. It was to the single soul, also, in the person of the individual convert, that the message of the gospel made its appeal. The Fathers held in common to the view that the soul was "spirit," personal in its conscious nature, and immortal; that it was created by God, who was also a person; that demons and angels existed; and that the Saviour was a mediating person, partaking of both divine and human characters, by whom the human soul was restored or "saved." The differences among them began in the discussion of further philosophical questions, by which they endeavoured to rationalise this body of doctrines in a system of apologetics.

Under these limitations, of course, psychology and philosophy could not be motived by strict observation or by free speculation. Thought was conducted from a platform of divine revelation and dogma. In all growing religious tradition, the assumptions underlying belief 
consist in a body of revealed or decreed truths; and further thought is confined to the exposition and defence of these truths in a system of apologetic interpretations. This aspect of the Patristic thought does not directly concern us; its psychology is soon summed up.

The controversy between "creationism" and "traducianism" concerned the origin of the individual soul. Creationism was the view that the soul was created by a divine act at the moment of conception. According to traducianism, the soul was passed from parent to child, in a new individual form, all souls having been potentially created in the first man.

The concept of personality had acute discussion, carried to the extremes of refinement by the Scholastics. The relation between divine and human personality was taken up; especially the relation between the two aspects in the personality of Jesus and among the three persons in the Trinity. These subjects, although standing mysteries, were nevertheless topics for theological definition. The purely logical and ex parte character of the results points the way to the formalism of High Scholasticism.

In Saint Augustine (354-430), however, the greatest of the Fathers, we find a mind formed in the mould of Aristotle. St. Augustine gathered into one the scattered results of what was best in Greek psychological thought. He 


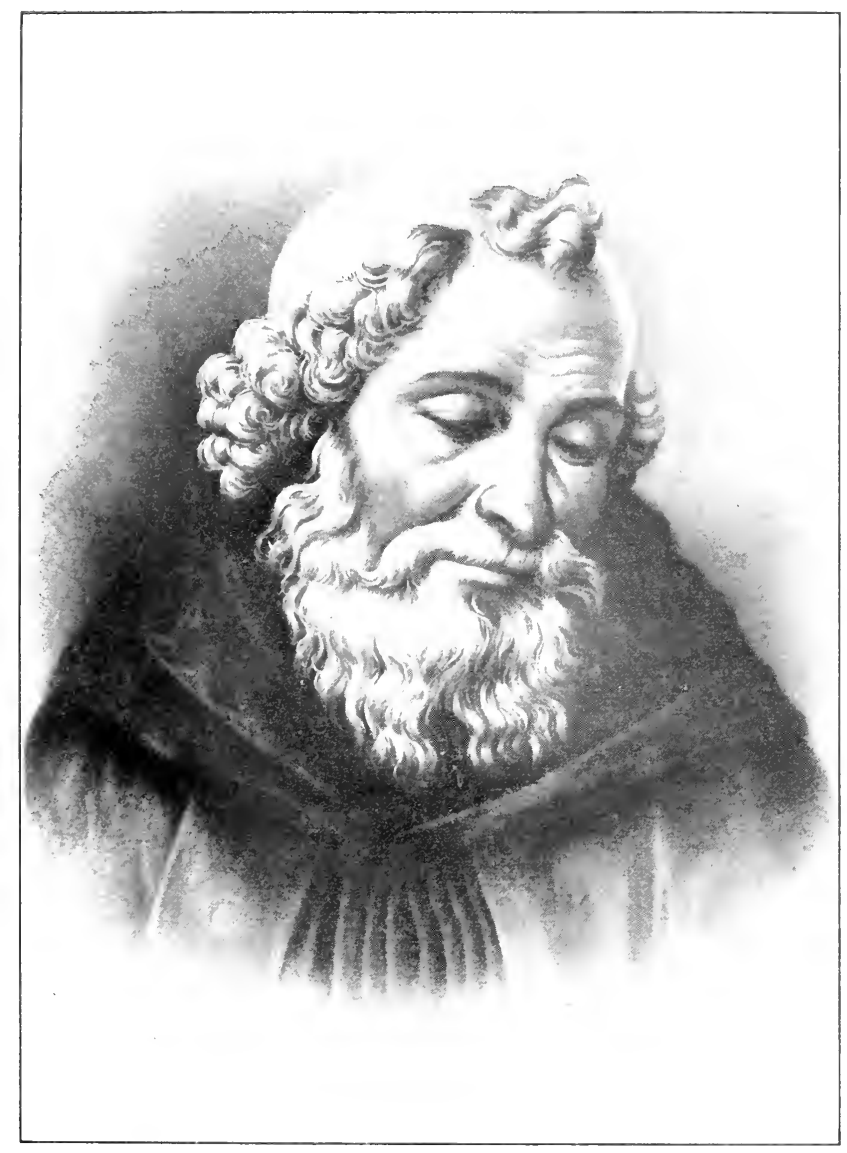

\section{Saint Algiostine.}

(Copyright. Reproduced by hind permis in of the Open Court Publishing Co., (hicago, U.S.A.) 



\section{Patristics, Scholastics, and Arabians 97}

held that the soul was to be approached and known directly through consciousness; that it was immaterial in character and immortal; that inner observation was possible and necessary. Resulting from such observation, he found that the mental life was one of continual movement in the one spiritual principle, and showed itself in three fundamental functions: intellect (intellectus), will (voluntas), and "self-conscious memory" (perhaps the best rendering of memoria, ${ }^{\mathrm{I}}$ as St. Augustine used the term). The fundamental moving principle of the entire mental life is will. The other functions manifest will.

This develops the Socratic tradition in the direction of the emphasis on conduct or activity, over against the rationalism of Plato. But in St. Augustine the emphasis on will is accompanied by a corresponding recognition of feeling; a position in which the religious interests and intuitions were no doubt involved, ${ }^{2}$ but which was none the less new and fruitful. His argument for freedom of the will, within the broad concept of determinism, is classical.

The soul has also the power of knowing itself;

"In "memoria" St. Augustine found the consciousness of self as identical (with Plotinus), as persisting (not selfforgetting-hence memoria), and as eternal. In memory, the distinction of past, present, and future are annulled in an intuition of eternity.

${ }^{2}$ As mediated through the Alexandrian tradition.

vol. $1-7$ 
the faculties turn in upon themselves; we reflect upon our own states of mind. This was to St. Augustine the key to divine knowledge; for in reflecting upon ourselves we discover the characters of the spiritual principle and of God. This is the end of all knowledge.

In such teaching St. Augustine shows himself to be after Aristotle the second great pioneer in the history of psychology. By him, the sphere of fact which psychology is to make its own is clearly marked out: the sphere of conscious events, apprehended by introspection. He also develops further the dualism of mind and body, by defining mind in terms of will and activity, terms which find their meaning only within the conscious life itself.

It was no doubt only his theological interest that kept St. Augustine from taking the radically dualistic step taken later on by Descartes, who denied all interaction of mind and body inter se in view of their disparity as substances. The resurrection doctrine and the theory which attributed to demons and angels the power of acting on the physical world may have contributed to keep St. Augustine from raising the psycho-physical question of interaction, and from answering it in the Cartesian manner. It appears to be clear, however, after all reservations have been made in the case of St. Augustine, that the absolute substantive separation of mind 


\section{Patristics, Scholastics, and Arabians 99}

and body is not reached in the Patristic writings, but rather a logical separation in the interest of the distinction between "spirit" and "flesh," between the "kingdom of heaven" and that of sin or "fleshly lust." Tertullian, another leading psychologist of the Latin Church, no less than St. Paul, argues for the resurrection of the body as part of the entire personality that is redeemed. ${ }^{\mathbf{x}}$ The risen Saviour preserves the same recognisable body, in the New Testament narrative. To certain of the Fathers (Tertullian among them) the soul is a sort of fine air-like stuff, diffused throughout the entire body-one of the many absorptions from Greek thought of views which proved to be available in the service of Christian dogmatics. ${ }^{2}$

Further, according to St. Augustine, by the knowledge of self, scepticism regarding the external world is refuted; for the self distinguishes itself from its objects. Whatever decep-

I"If the dead rise not . . then your faith is vain; ye are still in your sins." -I CoR. Xv. I6-I7.

${ }^{2}$ Harms, loc. cit., p. 208, probably goes a little too far in intimating that nothing in St. Augustine's recognition of the facts of consciousness is in contradiction with such a view of the soul. For St. Augustine not only argues against the corporeality of the soul, but finds its essence in the will, much as Descartes found it in "thought." In Nemesius,

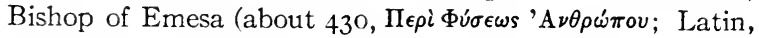
De Natura Hominis), we find a sharp dualism insisted upon, in opposition to the "entelechy" theory of Aristotle. 
tion or illusion there may be in sense-perception, it arises in the judgment or interpretation of sensation; it is not in the sensation itself. The belief that something real is external is proved by the facts.

In this a further most important phase of dualism discloses itself: that between the subject and the object of thought. In establishing this dualism, reflection passes into the clearly logical period; that is, it becomes conscious of itself as an activity of judgment; it interprets its own contents. The full results of this step appear, as those of the "substantive" distinction just mentioned also appear, only in Descartes. But it is safe to say that Descartes occupies the conspicuous place he does, in both of these respects, in part certainly, because of his historical position as following after the great Patristic writer, St. Augustine.

In considering Aristotle, we saw that psychology was pursued by him in the spirit of natural history, but without entire theoretical justification; to him mind and body were still united in the one p'ses; or "nature." St. Augustine took the further step that justified psychology as a science-having its own body of data, the data of consciousness, and its own method of procedure, introspection-by making the soul a principle different from matter, and known only in conscious personalities. The truth hinted at 


\section{Patristics, Scholastics, and Arabians IOI}

in the famous injunction, "Know thyself," of Socrates, passed into the equally famous response of Descartes, "I think, therefore I am"; and coming between them, the mediating doctrine of St. Augustine might well have been framed in Cartesian fashion from the words, "Volens, sum."

To sum up, we may safely say of St. Augustine the following three things: (I) he justified empirical psychology by separating off and defining the inner world of mind as distinct from physical nature; (2) he developed the dualism of mind and body up to the point at which their actual separation as different substances could be made by Descartes; and (3) he established the function of reflection, by which the self distinguishes itself as subject from the objects of its thought, thus carrying dualism on to a new stage of development.

II. The Scholastics. - The writers who are grouped under this title were also men enlisted in the service of the Church. The Church was the guardian of learning during the long period from A.D. 400 to I 400 . The religious orders in Paris and Oxford, led by dominant spirits, became camps of doctrine devoted here and there to the defence of this or that philosophical tradition in theology. Of the great Scholastics, Albertus Magnus and 
Thomas Aquinas were Dominicans, Duns Scotus a Franciscan. ${ }^{\mathrm{I}}$

The Aristotelian and Platonic directions of thought are plainly distinguishable, together with the mystic influence of the Alexandrians. Platonism appears early in the movement in modes of idealism which place emphasis on reason, the validity of general knowledge, and the more mystic forms of intuition fathered by Plotinus. Aristotelianism, on the other hand, gained complete ascendency in the later writers, both in the shape of a logical formalism, and in emphasis upon the validity of particular knowledge, the subordination of the idea or form to matter. It was probably only the really vital psychology of St. Augustine, with its emphasis on will and the concrete life, that saved the Church for long periods from the sterile logic and degenerate, or at least casuistical, practice that finally came to mark its intellectual and moral life.

The influence of St. Augustine showed itself in John and Richard of St. Victor in the twelfth century. The Abbots of St. Victor made out three avenues of knowledge - called by them "eyes of the soul": sense, reason, and intelligence.

IFull treatment of this period is to be found in the Histories of Philosophy. Especially authoritative are the detailed articles by Siebeck in Archiv für Geschichte der Philosophie, Bd. I-III, and Bd. X. 


\section{Patristics, Scholastics, and Arabians 103}

But these were stages in the progress of the mystic apprehension or contemplation of God, and the recovery of the soul from $\sin$. The problem of evil in the world, discussed by St. Augustine, was centred in that of the fall of man and the consequent reality of human sin. Error is the result of blindness due to $\sin$; $\sin$ is not, as Socrates had supposed, due to error. In all this mystic turn of view, feeling held the prominent place.

The psychology of St. Augustine also served to give analogies by which logical "realism" could be defended: the doctrine that genus and species have real existence in nature. The three faculties were present in the one soul, which was their genus; so also in the Trinity, the three persons, each real, existed in the equal reality of the personality of God. On the other hand, "nominalism," I the doctrine that the general, the genus, was only a mental representation, having merely nominal existence through the name attached to it, found reality only in the particular objects of external perception. The ideal form or type of Plato was replaced by the singular form of the object in which, on the Aristotelian view, it was embodied. This pro-

× Between Roscellinus and Anselm, nominalist and realist respectively, the controversy was joined. The middle or "conceptualist" view holds that general concepts contain knowledge of general realities. 
longed controversy had application, apart from formal logic, to theological problems mainly, such as those of the Trinity, the human race in general as involved in the fall and redemption, the nature of angels, etc.

This more psychological period of Scholasticism gave birth, however, to John of Salisbury (cir. I I50), a man who may properly be described as one of the forerunners of modern genetic psychology. This thinker worked out a theory of the continuous development of knowledge, pointing out the transitions of function as they actually take place from senseperception to reason. First appears sensation, and in it the germ of judgment; then imaging, with a further development of judgment in the direction of the valuation of experience, from which arise pleasure and pain, the basis of desire. Out of imagination springs rational knowledge, and through it comes wisdom, the contemplation of God.

This remarkable anticipation of the genetic point of riew, giving as it did specific content to the theories of mental activity, movement, and will of St. Augustine and the Monks of St. Victor, remained quite fruitless. It was swamped by the flood of High Scholastic subtleties that the swelling current of verbal logic bore with it.

Albertus Magnus, Thomas Aquinas, and Duns 


\section{Patristics, Scholastics, and Arabians 105}

Scotus are the commanding figures of "High Scholasticism." With Albertus (I 193-I280) we find the clear enunciation of the doctrine of "creation out of nothing" which broke once for all with theories of emanation and of the eternal existence of matter. Matter was the product of a divine "fiat"-whether intellectual or volitional, opinions differed. The human soul was included in the act of creation, but it was made in the likeness of God. That is, it was rational and personal.

Thomas Aquinas (1227-I274), the Angelic Doctor of modern Roman theology, developed an acute and modern-sounding theory of the mutual relation of reason and will. Each is dependent upon the other: knowledge is instrumental to action; and action contributes to knowledge. Thomas also confirmed the Aristotelian distinction between active and passive reason, as well as the doctrine of matter and form. The rational soul is a principle which has its form entirely within itself; it is not, like the sensitive and animal souls, subject to stimulation from the external world to which it reacts. In this theory, the doctrine of matter and form is revived and extended. The rational soul, like God and the angels, is pure form; and as such it is immortal. The lower soul is a sort of form which inheres in matter and constitutes the principle of vital organisation. The active 
reason or pure form, however, exists only along with the passive reason, and is always personal. Within the function of knowledge, the rôle of active reason is to reach general or abstract concepts, the logical species or kinds which underlie sense-percepts and images. Sensation itself is not due to the transfer of material images or effluvia, but is in principle a mental or spiritual impression.

The significance of Thomism for us would seem to reside in the truce it declared in the rivalry between the biological and theological conceptions of the soul. The soul is rational; but its life takes on a personal form, which includes the biological aspect of individuality. Preserving the psychological point of view of St. Augustine regarding personality, St. Thomas endeavoured to avoid a sharp dualism of person and matter by a return to the matter-form theory. Like other compromises of the sort, it has not had the influence, outside of Church circles, that the genius of its author descrved. Catholic writers, however, justly cite it, and also the many isolated points in which St. Thomas anticipated the results of modern thought. Thomism also had the merit of so far justifying a naturalism in scientific point of view, and so of encouraging a tolerant attitude toward modern science.

In Thomism, however, we see the logically opposing concepts of biological form and rational 


\section{Patristics, Scholastics, and Arabians 107}

spirit held together by the recognition of the unity of personal experience as being subjective. This is the gain to thought that St. Thomas received from St. Augustine and confirmed by his own authority.

Duns Scotus (Duns, the Scot) (cir. 1265-1308), a Franciscan, reasserted vigorously the subjective point of view and insisted upon the primacy of the will. Creation is an act of divine will; and the world is constantly renewed by the continuing will of God. Further, the individual will is back of knowledge, even knowledge of self. The end of existence is the Good, which is reached by will; intelligence is instrumental, the servant of action. Sin is a perversion of will, causing intellectual blindness, and sin is possible because the will is free.

A "suggestion" or "first thought" enters consciousness, serving as stimulus to the will; the will responds to it, embracing or rejecting it; it thus becomes a "second thought." It is this second thought, the object of will, to which the agent's freedom and responsibility attach. Good and evil do not belong to things in themselves, but to the use made of them in the voluntary "second thought" of the agent.

Duns Scotus, following the leading of St. Augustine, distinguished the emotions or "passions" as a fundamental class of mental phenomena. Before him the Scholastic leaders had 
looked upon feeling as a modification of impulse and desire, following the Aristotelian division.

An interesting variation upon the discussion of realism and nominalism, already spoken of, arose regarding the relation of the faculties to the "inner sense" or consciousness as a whole. Aristotle had asserted the oneness of mental function in the common sense, the Platonic "parts" or divisions of the soul being merely powers or activities of the one conscious principle. This became one of the burning questions of late Scholasticism. William of Occam maintained that all the "representations"-sense-perceptions, memories, concepts, etc.-were merely mental signs or symbols of varying orders, arising at different stages of mental function; ${ }^{\mathrm{I}}$ they were not pictures of different realities perceived by fundamentally different faculties or powers.

This raised in turn the more subtle question as to the sorts of reality arising respectively in percipi and in re, in the mental symbol and in the external world. Aristotle had held that the objects of sensation and thought were really, that is formally, present in the sensation and thought. To Plato, the idea was itself the true existence or reality in se. Thomas Aquinas developed a view according to which existence was "intentional" in thought; and Anselm of

'See the exposition of Siebeck, Archiv für Geschichte der Philosophie, Bd. X. 


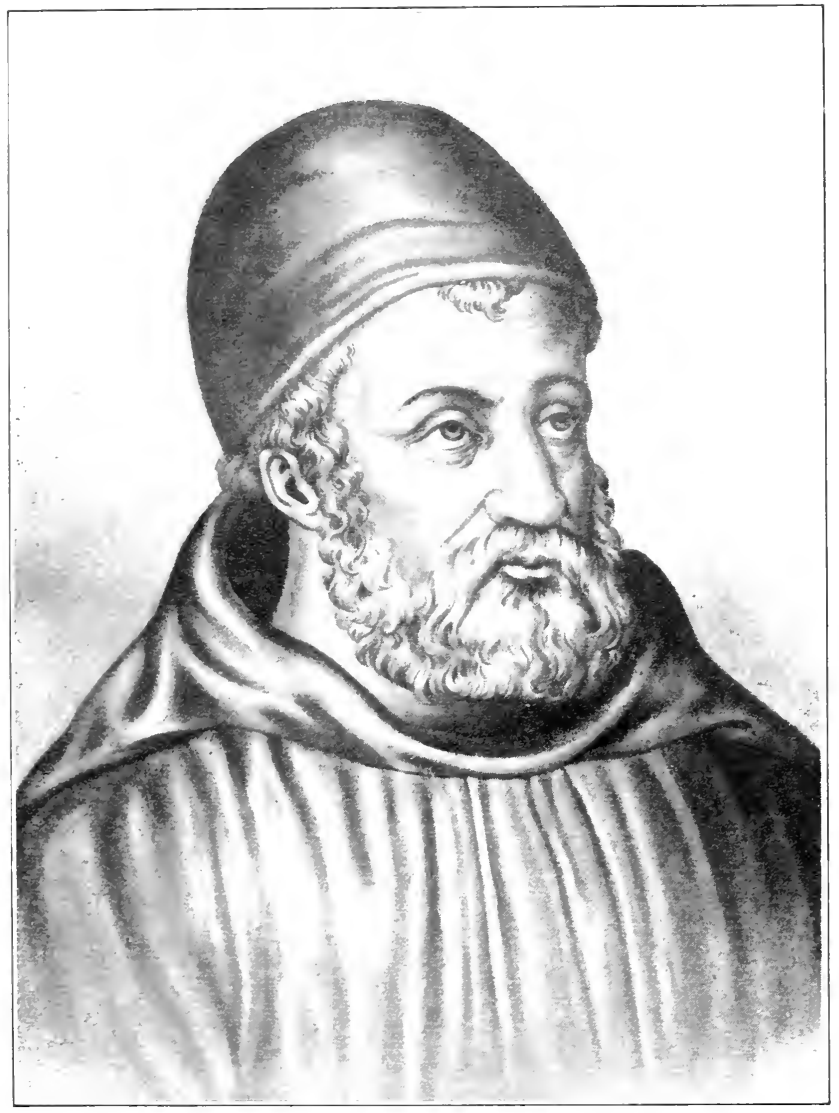

\section{Dixs Scotes.}

(Copyright. Reproluced by kind permision of the ()pen Court Publishing Co., Chicago, L...A.) 


$$
\text { . }
$$




\section{Patristics, Scholastics, and Arabians 109}

Canterbury based his famous argument for the existence of God on the proposition that the idea of a perfect being must imply his existence; for otherwise, lacking existence, the perfection presupposed in the idea would be impaired.

Summing up the characters of Scholasticism, we may say: (I) that the philosophical and psychological treatment of the problems of mind yielded to a logical and theological treatment; (2) that the points of view developed in these discussions-those of realism and nominalism, of traducianism and creationism, of determinism and accidentalism, ${ }^{\mathrm{I}}$ of emanation and creation, of secondary spiritual existences, such as spirits and demons-all proceeded upon the presupposition of the authority of the Scriptures; (3) that, so far as progress was made in psychology, it was made by bringing to explicit recognition the data of earlier thought which lent themselves to such presuppositions; namely, the nature of thought and will and their relation to each other, the essentially empirical unity of consciousness, the theory of conscious personality; (4) that the dualism of mind and body received a temporary and dogmatic interpretation in the doctrine of creation, matter being "made of nothing," while soul arose from the "breath of God" and took form in His image.

'Renewed later on as between "Calvinism" and "Arminianism." 
III. Arabian Physiological Psychology.-Contemporaneously with the earlier Scholasticism, a movement of interest developed among the Arabians who received, especially in Syria, the tradition of Western learning.

Avicenna (Ibn Sina), the physician of Ispahan (died 1037), was the first to investigate the actual relation of mind and body, especially as shown by movement. He distinguished the movements of the body which were variable and uncertain as being caused by the rational soul, which thus showed itself to be a force foreign in principle to the body. He enumerated five inner senses, located in the brain, in correlation with the five outer or physical senses: they were "common sense," "imagination" (located in the frontal region of the brain), "sense judgment," "memory" (in the posterior region), and "fancy" (in the middle region) - the last having the value of warning in the presence of good and ill. Sense knowledge issues in movement; and movement in turn contributes to rational knowledge, which is of the absolute. The rational soul, being a simple substance, is out of space and time and independent of the body.

Goodness and truth are reached by the denial and subjection of the body, by abstraction of the self from sensible experience, in order that illumination may come into the soul. Here a strain of oriental mysticism shows itself. 


\section{Patristics, Scholastics, and Arabians II I}

Allacen was the author of a remarkable book on "Optics," written quite in the spirit of the latest treatises on the physiology and psychology of vision. He treats of visual sensation proper, colour, visual space perception, the perception of depth, the dependence of size upon the visual angle, the assimilation of memory images to visual percepts (finding here the basis of resemblance, conception, and thought), the time required for the propagation of the impulse from the eye to the brain, indirect vision, eye-movements, etc.-problems which stand foremost in the contents of our most modern treatises. $\mathrm{He}$ anticipated the Helmholtz theory of "unconscious judgments" in visual space-perception. $\mathrm{He}$ also investigated various problems of time, as well as of space, as revealed by visual phenomena, and from such questions went on to consider the problems of apperception and illusion. ${ }^{\mathrm{r}}$ Alhacen's influence appears sporadically in later thinkers. He was cited by the more empirical Scholastics, such as Roger Bacon.

In Averroës (died II98), finally, the psychophysical relation was interpreted in a materialistic sense. But, on the other hand, a general and impersonal existence was attributed to the rational principle, to which the individual soul

I Alhacen's work was translated from the Arabic in 1269. A concise list of the main topics treated by Alhacen is to be found in Klemm, loc. cit., pp. $327 \mathrm{ff}$. 
might attain by abstract thought. This combination of pantheistic impersonal reason, with naturalism or materialism in the domain of empirical knowledge, also anticipates a mode of very recent speculation.

The advance, psychologically speaking, made by the Arabian psychologists is in the direction of a statement of the psycho-physical problem as one demanding actual research. The dependence of the mind upon the body, together with the laws of correlation of the two classes of phenomena, is the main problem of modern physiological psychology. Besides this new conception of method, they reached-Alhacen especially - valuable positive results.

IV. The Mystical Reaction.-The reaction against the logical refinements of the Scholastics - which often degenerated into barren verbal distinctions-showed itself strongly in the various groups of Mystical writers and in the rise of empirical science. The latter will be spoken of again below.

Meister Eckhart (cir. I260-1327), the mystic, answered the question of the primacy of principle as between intelligence and will, by including them both in a state of feeling-the German Gemiuth. By the apprehension of God in an ecstasy of feeling, knowledge and aspiration are fused and completed. This reinstated, in view 


\section{Patristics, Scholastics, and Arabians II 3}

of the alternatives of the time, the immediateness reached in their day by the Neo-Platonists; and it represented about the same motives of reconciliation. It was made logically less difficult by the Thomist revival of the doctrine of matter and form, which reduced the opposition between mind and body, and by the Augustinian emphasis on will. Eckhart was a disciple of Thomas, and a fellow Dominican. The unity of the conscious functions in feeling he called the "spark" of divine light which directed man to God; in it the dualisms and oppositions of human faculty were submerged and overcome.

The name of John Tauler (cir. I290-I36I) is associated with that of Eckhart. $\mathrm{He}$ also shared the doctrine of feeling or Gemüth. Both alike drew inspiration from their great predecessor in mystic apprehension, Plotinus.

Like the Neo-Platonic movement, this turn to mysticism showed the demand of the mind for an escape from the partial mediations of reality effected by thought and action, together with the satisfaction of this demand in a mode of higher unity achieved when the whole personality pours itself out in feeling.

vol. $1-8$ 


\section{PART IV}

MODERN PSYCHOLOGY. FIRST PERIOD, TO THE NINETEENTH CENTURY

\section{CHAPTER VII}

\section{The Interpretation of Dualism}

I. The Modern Schools. - With the development of the dualism between mind and body up to the stage it reached in René Descartes (of whom we are now to speak), the period properly to be called "modern" commences. The meaning is not one, however, merely of modernness in time; but of modernness, first of all, in the essential state of the problems of philosophy and psychology. Up to the present, we have traced the progress of the interpretation of the world and the self as it worked out the distinction between mind and matter. The terms of that distinction being now understood, as distinguishing two substances sharply contrasted and actually separated from each other, speculation takes the form of the interpretation of this 


\section{The Interpretation of Dualism}

dualism itself. If we look upon the earlier thought as being a spontaneous or direct consideration of nature and man, we may look upon the latter as being a reflection upon the result of this former thinking. The dualism itself becomes a sort of presupposition or datum; its terms condition the further problem. How can mind and matter both exist and give the appearance of interaction?-which of the two is the prius of the other?

These questions, as now formulated, show later thought to be an interpretation of dualism, as the earlier was an interpretation of the world in terms of dualism. While the ancient and mediæval philosophies developed a progressive distinction and finally a divorce between body and mind, the modern results in a series of attempts to accommodate them to each other again in a single cosmic household. How can the world contain two such disparate principles, and how are we to conceive of their final adjustment to each other in the nature of reality?

Psychology reflected, for a long time, the alternatives worked out by the earlier philosophical schools. So much so that the theory of the mind remained an appendage or corollary to philosophical doctrine. The alternatives were plainly enough marked, and terms have grown up to characterise them.

One may accept the dualism and devise 
a theory of mutual adjustment of the two substances to each other. This was the course pursued by Descartes, Malebranche, and Spinoza, and gave rise to a series of doctrines which we know as "dualistic," "realistic," and "absolutistic." I

But interpretation may take a different turn; mind may be made the prior term, the basal explaining term, matter being reduced to mind, or its substantial character explained away. This was the method of two great schools of "idealists," one party, the Intellectualists, finding the universal solvent in the intelligence or reason: so Leibnitz, Wolff, Kant, Berkeley, Hegel. They produced the psychology found in the "dogmatic," "critical," and "subjective" systems of philosophy.

The other party of the idealists, the Voluntarists, sought the fundamental principle in will: so Fichte, Schelling, Schopenhauer, and many others.

These two schools re-introduce the motives of Greek "subjectivism" and Platonism, on the one hand, and of the voluntarism of St. Augustine on the other.

But in like manner the second term of the

${ }^{x}$ In an interesting passage, Harms (loc. cit., p. 243 ) makes the very valid point that it was only the radical dualism of Descartes that made possible the theories of "occasionalism," "harmony," etc., of his successors. 


\section{The Interpretation of Dualism}

dualism, matter or body, was given priority equally by others, the independence of mind being denied. So arose reflective "naturalism" and "materialism": Hobbes, Hartley, Condillac, Diderot. In this the motives of Greek "objectivism," Aristotelianism, and Atomism reappear.

Finally, as in the spontaneous development of Greek thought, all of these-subjectivism, objectivism, dualism - may be combined in a theory of higher intuition, of the fusion or synthesis of contemplation. This embodies the "mystic" motives of feeling and faith, or makes the speculative claim of uniting the divided and partial motives of the other theories in a higher intuition; so the Mystics, the Faith Philosophers, the Intuitionists, and the æsthetic Immediatists.

In the first period of modern thought, therefore, we may recognise the psychological tendencies going with these philosophical alternatives.

(Modern Psychology)-

I. Philosophical Psychology.

A. Dualistic and Realistic.

B. Rationalistic $\left\{\begin{array}{l}\text { Intellectualistic. } \\ \text { Voluntaristic. }\end{array}\right.$

C. Naturalistic and Materialistic.

D. Mystic and Affectivistic. 
This more philosophical treatment did not deny to psychology its scientific place and method, so far as these had been determined. As we are to see, the objectivism and naturalism worked out by Aristotle, St. Augustine, and the Arabian physiologists remained the fruitful instruments of scientific discovery. And in the theoretical development of naturalism in the other sciences-physical, vital, socialpsychology was to share. An explicit naturalism of subject-matter was to arise, supplemented by an equally explicit positivism of method. This was the line of progress in all the sciences alike. If we describe the new and more scientific psychology as empirical and positive, we may treat of the main groups of thinkers under the headings of theory, method, and matter.

As to theory, the step in advance consisted in a transition from a deductive or logical interpretation of mind, which impaired the purity of empirical observation, to a full and unrestricted empiricism. F. Bacon, Rousseau, Comte, and J. S. Mill are among the important figures in the history of the development of the theory.

In the application of such a theory, variations are again possible, extending from mere description and classification to genuinely analytic, constructive, and experi- 
mental procedure. Descriptive psychology as such had its apostles in Locke, Hume, Taine, James Mill, Bain, Hodgson; constructive psychology in Herbart, Spencer, Lotze, William James. Such psychology is often called "structural," from the nature of its results.

Under the heading of method, the change in point of view brought about by the theory of evolution is to be considered. The genetic method has worked its way into all the sciences of life and mind. Here Darwin, Wallace, Beneke, Romanes, Ribot are names to be cited. Under certain of its aspects, as contrasted with analytic or structural science, this is called "functional" psychology.

The development of recent psychology has resulted, finally, in the growth of certain subdivisions, each having its own subjectmatter, and each adopting the most available method. So "physiological," "social," "comparative," "experimental" and other "psychologies" have arisen. Each has today its apostles and its group of enthusiastic workers.

The headings of our treatment of the second period in modern psychology, therefore, will be as follows in the table, which forms the second part of a larger one, the first part having been given just above. 
(Modern Psychology)-

II. Empirical and Positive Psychology.

A. As to Theory $\left\{\begin{array}{l}\text { Empirical. } \\ \text { Positive. }\end{array}\right.$

B. As to Method $\left\{\begin{array}{l}\text { Descriptive. } \\ \text { Constructive (struc- } \\ \text { tural). } \\ \text { Genetic (functional). }\end{array}\right.$

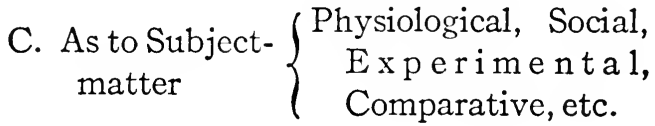

II. The New Departures: The Empirical Method.-The coming of a new method ${ }^{x}$ had its early prophets even among the scholastics; as in Roger Bacon (died 1294) and William of Occam (died 1349), who with Duns Scotus and John of Salisbury investigated knowledge empirically. On the side of physical science, the Copernican theory, through the work of the astronomers Kepler and Galileo, became revolutionary and far-reaching for science in general. In Kepler, the theory of physical action took on

'Apart from method-which was the main thing for science-certain events and influences made the period truly remarkable. The discovery of America, the revival of letters in Italy, the German Reformation, all illustrated the new spirit of vigour and enterprise. The mystical thought of Bruno and Campanella faced forward toward the universal doubt of Descartes, rather than backward toward the universal authority of the Church. 


\section{The Interpretation of Dualism}

a more mechanical and quantitative character. Many analogies drawn from the old animistic conception of nature were banished. Movements of attraction and repulsion were accounted for on mechanical principles. ${ }^{\text {I }}$ Newton's demonstration of universal gravitation was alone needed to vindicate the conception of natural law; and mechanical analogies began to creep into psychology in the form of attraction, repulsion, and interference-full mechanical interplay, in factamong ideas.

The names of Vives and Francis Bacon are of especial note in the Renaissance period.

Ludovicus Vives (I492-I540) proclaimed the independence of mental phenomena, considered as the matter of psychology, and protested against the metaphysical point of view, with its empty discussions of the essence of the soul. He was also an early investigator of the laws of association of ideas.

Francis Bacon (Lord Verulam, I561-1626) is usually called the father of empirical scientific method. His work consisted in an attempt at restoring knowledge to the path of fact and to the service of utility. $^{2} \mathrm{He}$ led a revolt against

I Kepler made interesting contributions to the physiological psychology of vision, establishing the colour changes of after-images and the fact of the formation of the visual image on the retina.

2See R. Adamson's citation of passages showing Bacon's 
formalism of view and prejudice of temper. He pointed out the various hindrances (idola ${ }^{\mathrm{r}}$ ) under which the pursuit of truth is prone to labour. He attempted to classify the sciences, ${ }^{2}$ to limit and define philosophy, and to formulate a sound experimental method whereby the sum of knowledge might be augmented. This programme was of service, of course, to all the sciences alike, mental as well as physical. It proved most difficult of realisation, however, in psychology and the moral sciences.

The Renewal of Mysticism.-After àn interval of two and a half centuries, the tradition of mystic illumination renewed itself in Italy and Germany. A group of mystic thinkers in whom the romanticism of the Renaissance shows itself is composed of Paracelsus (I493-I54I), Telesius ( I 508-I 588), Campanella ( I 568-r639), Giordano Bruno (I548-I600) and others, principally Ital-

insistence on the utilitarian or pragmatic function and value of knowledge, in the article "Bacon," Encyclopadia Britannica, Ioth edition. The object of knowledge to Bacon is the control of nature by man (imperium hominis).

${ }^{1}$ Novum Organum, Part I, English edition, with Notes and Introduction by Fowler (2nd ed., I 889).

2 Bacon's classification is based upon the analysis of the faculties of knowledge into memory, imagination, and reason, which underlie respectivcly history, poetry, and philosophy with science. 


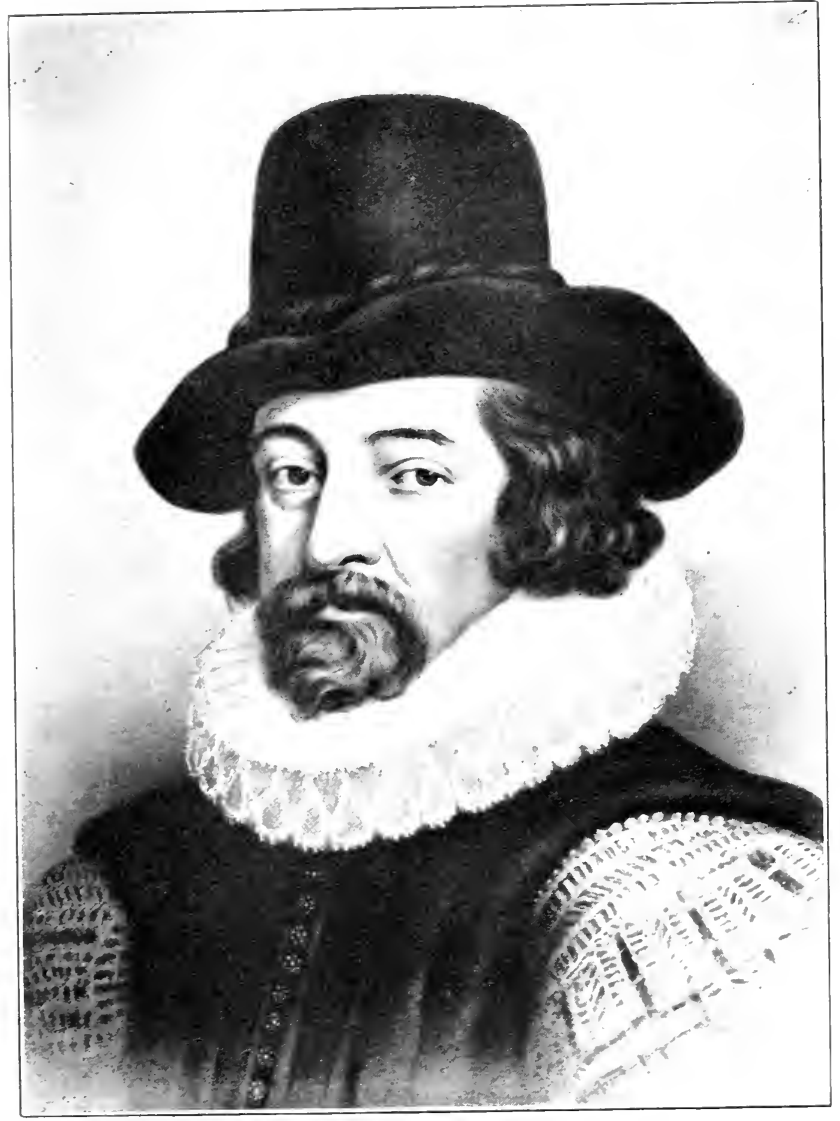

Fraxcis Bacon.

(Copyright. Reproduced by kind permission of the ()pen Court Publishing Co., Chicago, L....A.) 


\section{-}




\section{The Interpretation of Dualism}

ians. $^{x}$ These men show a breaking up of classical theories into disjecta membra, and (as seen in Telesius particularly) the bizarre rearrangement of the fragments, mingled with detached original aperçus. A valuable departure was made, however, in the view of the imagination which runs through their writings. The imagination (imaginatio) is looked upon as, in various ways, mediating between sensation and reason; it completes the detached data of sense, building them up into ideas, and offers preliminary schemata or ideal constructions to the reason. This is an anticipation-and on the whole a clearer statement-of Kant's view of the "schematising imagination"; it also suggests the very modern doctrine of the assumptive and experimental function of the imagination, with the application of that view in the analysis of the "semblant" products of play and art.

It is interesting that this should have been hit upon by writers of a mystic cast of thought. It constitutes an important step in the development of mysticism out of the status of emotion and sentiment into that of a rational constructive theory. If the imagination accomplishes in its normal working the results formerly attributed to emotional intuition and ecstasy, then this type of apprehension may be put down as one

IA sympathetic recent work is by R. Steiner, The Mystics of the Renaissance, Eng. trans. (1912). 
of the recognised functions of cognition. This means that the psychology of the imagination takes its place among the larger problems of the theory of knowledge.

In Jacob Boehme (1575-1624), the full dualism of the pre-Cartesian era is as urgent for expression as in Descartes; and the antithesis between the two is very interesting. The one, the Academic philosopher and acute mathematician, argued from the standpoint of universal doubt and made the fewest, only the necessary, assumptions. The other, a plain workman, seeing by intuition and speaking by "revelation," made known the mysteries of faith.

Boehme reverses the method of that other great mystic, Plotinus, who proceeded to transcend all dualism in the abstraction of the impersonal and absolute One. Boehme finds that only by dualising itself in subject and object could the divine principle become self-conscious spirit and be apprehended as such. Opposition, limitation, and reconciliation are necessary for the manifestation of the attributes of reason, will, and love. God is self-generated, through opposition arising in his own nature. Knowledge and self-consciousness are possible only through opposition and duality. ${ }^{\mathrm{I}}$

In regard to both these relations-Boehme's

'See the elaborate study, "Boehme," in Boutroux's Historical Studies in Philosophy, Eng. trans. (I912). 


\section{The Interpretation of Dualism}

relations to Descartes and Plotinus (and similarly to Spinoza)-the following passage may be quoted from Schwegler: "Compared with Descartes, Boehme has at least more profoundly apprehended the conception of self-consciousness and the relation of the finite to God. But his historical position in other respects is far too isolated and exceptional, and his mode of statement far too impure, to warrant us in incorporating him anywhere in a series of systems developed continuously and in a genetic connection." We must take exception, however, to the last statement made in this citation; for though isolated in fact, still Boehme was not isolated as to the "genetic connection" of thought understood in a sense larger than that defined by the term "systems." The clear light of the dualism of subject and object, kindled by meditation on Christian truth, illuminates his page through the lens of mystic intuition; just as the same light, kindled by philosophical reflection, falls upon the page of Descartes through the lenses of reason and doubt. ${ }^{2}$ In the dialectical process

${ }^{x}$ Schwegler, History of Philosophy in Epitome, Eng. trans. (I886), p. 99.

${ }^{2}$ In the Christian mystics, the direct result of the profound realisation of sin and redemption, as set forth in the Christian theology, is a sharpened distinction between the divine Person and the human self. Self-debasement, laceration of spirit, adoration and praise, take the place of the personal absorption and union with God of Greek mysticism. 
of the self-generation of God, a process of progressive oppositions and reconciliations, Boehme supplied the main motive to the subsequent logical idealism of German philosophy. ${ }^{\mathbf{I}}$

The Individual Analogy.-The course of spontaneous philosophical reflection has been seen to present striking analogies with that of the individual. We have seen that they both proceed upon the same lines up to the full dualism of mind and body which precedes the function of reflection upon that dualism itself. We are now in the presence of the transition in racial thought from the spontaneous to the reflective type; and we cannot better understand its factors than by making brief comparison again with the similar transition in the individual, referring to the chapter on this subject (Chapter VII, Vol. II) for further details.

The individual becomes logical or reflective when he becomes aware that the material of his experience is not at once and immediately available in the form in which he takes it to be realas, body, soul, truth, etc.-but that he has to work by means of his consciousness, by the instrumentality of his memories, ideas, and concepts. He judges of his experience, criticises

r On this account he was called-as we are told by the arch "dialectician" of the entire movement, Hegel-the "Philosophus Teutonicus." 
his images, selects from appearances, rejects phantasms and illusions; in short, he interprets the data presented in his consciousness, and thus establishes results that he finds fit to be trusted and acted upon. This is reflection. The entire body of life's events, all the happenings of every kind, are set up in the mind; the objective facts are, as we say, "mediated" by ideas. The subjective point of view asserts itself; and it is only by taking account of it and working through it that mind and body are confirmed and interpreted.

This interpretation is in all cases conditioned by the dualism already established by spontaneous experience. The individual's ideas come to him bearing the marks or coefficients of their origin in the realms of matter and mind respectively. His further task is confined to affirming, denying, criticising these two forms of existence - so far as the contents in mind are not altogether fugitive and meaningless.

In doing this, further, he finds two available methods; there are two sorts of mediation effected by ideas. Ideas serve as instruments to secure voluntary ends (the thought of a danger, for example, leads to safety in flight); this is the mediation of the good or of value. But ideas serve also to mediate facts or the true (my idea of a locality enables me to go to that locality or to make true inferences regarding it). In these 
ways, the idea mediates both the actually good, which is an end for the self, and the actually true, which is a system of things apart from the self. The terms mediated, therefore, are the self and the not-self: the thinking self and the object of thought. This is the dualism established by reflection. It results from the interpretation of experience, found to be subjective, in terms of the dualism of mind and body.

Further, the individual has another course open to him by the use of his imagination; by this he idealises experience in the manner described more fully below. ${ }^{\text {I }} \mathrm{He}$ indulges in hypotheses, postulates ideals of value and truth, erects absolutes of beauty, personality, etc., and by these explains, in some further term of unity, the dual actualities of thought and things. He then leaves the realm of the actual, and becomes in some sense an "idealist," possibly a "mystic."

It is clear, then, that to the individual, if he is of the sort to think upon the problems of life and mind, certain alternatives are open. (I) $\mathrm{He}$ may remain simply a dualist, the self and the world being equally real and ultimate; or (2) he may accept as valid the reference of ideas to things, the mediation of facts and truths; and build up a scientific view of the world that is naturalistic and materialistic. The other sort ¿ Chapter VIII, Vol. II. 
of mediation, that of the good or the self, is neglected or denied. Or again, (3) he may accept the mediation of the good, establishing the reality of the self, but finding that it in turn subordinates or abolishes the other term, the world of things. Again, (4) he may not stop with such a result of actuality or fact of either sort; but go on to reach an imaginative ideal, either in terms of intelligence, giving finality to ideas as such, or of will, giving finality to ends as such. He then becomes either an intellectualist or a voluntarist. Or yet again, (5) he may make appeal to some more inclusive mode of reality, not exhausted by these two sorts, but including and reconciling them: the ideal Good, the Beautiful, God as absolute principle.

It will have become clear to the reader that these alternatives re-state the main directions of modern philosophy; and that under one or other of its headings each of the great currents of thought may be set down. We now see that these are likewise the alternatives open to individual reflection. If one ask one's casual acquaintances for their views of the nature of the world, one will find among them some common-sense dualists, some scientific positivists and materialists, some idealists either intellectualistic or voluntaristic, and some mystics, full of ideals of faith and beauty, but unlike all the rest unable to tell just why. Each is a potential 
member of an honourable historical school; each is, in fact, a spiritual brother of some one of the company of prophets-Democritus, Plato, Aristotle, St. Augustine, Plotinus-by whom the great alternatives of modern speculation were first thought out in simpler form. 


\section{CHAPTER VIII}

\section{Philosophical Psychology-Dualism, Rationalism, Dogmatism}

I. Descartes (1596-I650).-It has already been intimated that René Descartes stands at the portal of the temple of modern philosophy and psychology. It is not by reason of absolute originality of view that he holds this position, but by reason of the explicit statement he gave to views, and the new synthesis he gave to thoughts, which had been stated before him only partially and in relative detachment. The essential advances which Descartes representsapart from the question of method-are two, both of which we have had reason to refer to already.

In the first place, Descartes stands for the most explicit and uncompromising dualism between mind and matter. His position is not only clearly stated, but defended in detail. $\mathrm{He}$ distinguishes mind and body as two substances separate and incompatible. They have different properties, each its own specific characters 
or marks. The essence of body, he says, is "extension" ; and the essence of mind is "thought." These two substances are known in different ways; they form the subject-matter of different scientific interests; they are investigated by different methods. The method of the physical sciences is mathematics. Here Descartes, as the philosopher, opened up a new vista to modern thought. ${ }^{\mathbf{1}}$ The method of psychology, the science of mind, on the contrary, is introspection, inner observation of the events of consciousness. It is in this last point that we come upon a second position by which Descartes gave a large measure of justification to modern psychology.

This second position is summed up in the famous Cartesian motto, "I think, therefore I am." In this sentence, the criterion of mind, as Descartes conceived it, which was also its specific character, was given formal statement. Mind differs from body by its consciousness of its own thinking process; and in this it finds the immediate evidence of its existence as a peculiar mode of reality. The formal mode of statement should not obscure the essential import. It is not an argument, properly speaking, for the thinker himself; it is such only to the outsider. To consciousness, to the thinker himself that is, it means, "I am here thinking," "I catch myself

${ }^{2}$ Descartes founded the branch of mathematics known as Analytic Geometry. 


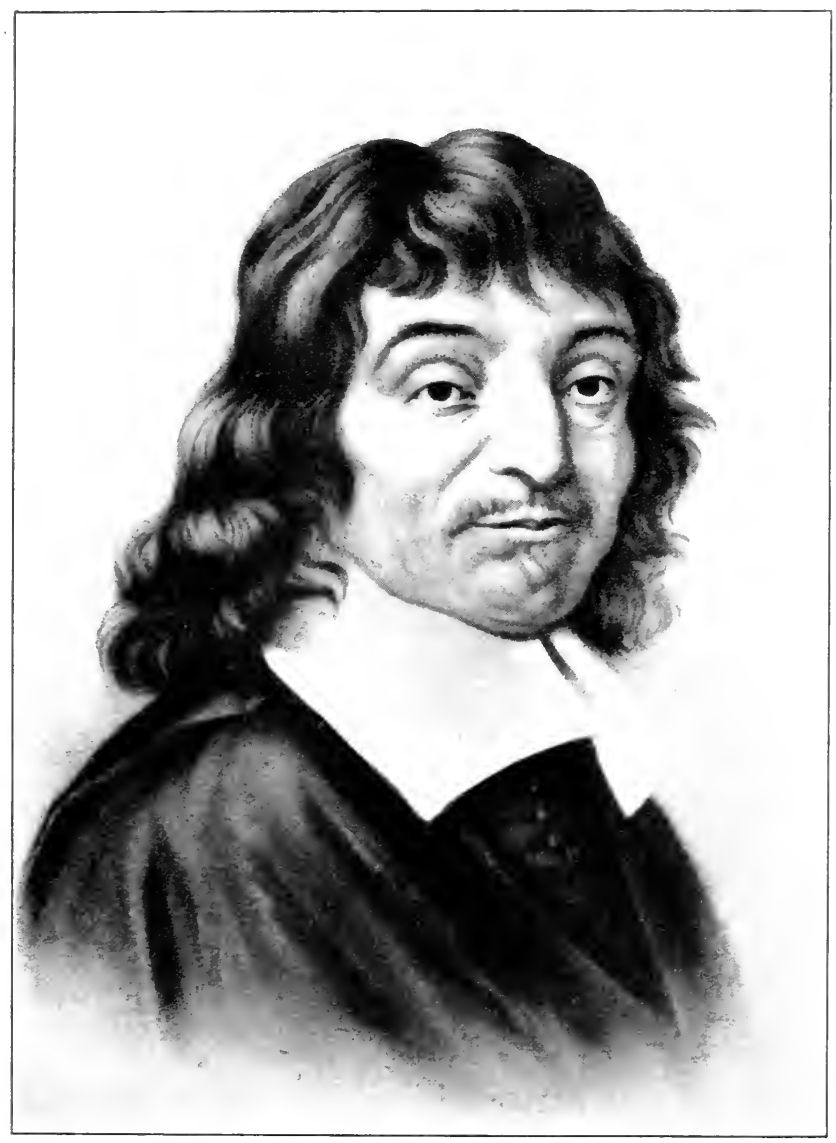

René Descartes.

(Copyright. Reproduced by kind permission of the Open Court Publishing Co., Chicago, L.......) 
$$
\text { . }
$$ 


\section{Dualism, Rationalism, Dogmatism I 33}

having thoughts," cogitans, sum. To the outside observer it means that by its thinking the mind knows itself to be different from matter, which is extended, and to be a sort of existence or reality sui generis. ${ }^{\mathbf{x}}$

The significance of both these elements of Cartesianism appears from the preceding history. They were both equally inevitable and both at the time equally mature. The final culmination of the mind-body dualism was prophesied in the first suggestion of the distinction made by Empedocles and Anaxagoras, and developed through all the vicissitudes of Greek and Mediæval philosophy. So plain is this that we have been justified in describing the progress of philosophy so far as the genetic history of dualism. Moreover, it is matched, in its main stages, by the similar history of the individual's thought. The individual grows to know the "self" as a principle different from body. In both alike, the issue in a hard-and-fast substantive dualism seems inevitable: there is an extended body, existing over against a conscious spirit or mind. The dogmatic spiritualism of

II is by a resort to "universal doubt" that Descartes establishes this; the only thing to which effective doubt cannot attach is self-consciousness, since to doubt this is to question the very process of thought in which doubting itself consists. The "I am" is necessary for the "I doubt." 
the Church fathers receives now the authorisation of speculative thought.

The point of novelty in the Cartesian statement consists in this, that the dualism becomes an ontological one; it does not remain merely logical, religious, practical, but becomes metaphysical - a formula of reality, the presupposition of future science and philosophy. So definite is this that the interest after Descartes consisted no longer in pointing to evidence of the disparate nature of mind and body, but of finding a method of accounting for their seeming relation and interaction. The dominant problem of the thinkers immediately following Descartes was the psycho-physical one: how could the two heterogeneous substances, mind and body, sustain any relation at all to each other?

The second position, embodied in the saying, cogito, ergo sum, is also the issue of a long travail. Rising in the relative isolation of the subjective point of view by the Sophists and Socrates, the current of subjectivism gathered force in Platonism, Mysticism, and Stoicism, and finally became fully aware of itself in St. Augustine, who might have said in form, as we have before remarked, "I will, therefore I am; volens sum." This current had to rid itself of the jetsam of Aristotelianism which obscured the subjective in the vital, and of the flotsam of both Platonism and Sensationalism, which equally, though in 


\section{Dualism, Rationalism, Dogmatism I 35}

different senses, deprived it of its true meaning. But the inner point of view constantly gained in clearness, and finally defined itself in essential terms: the point of view of consciousness as essential mark of mind and starting-point or presupposition of reflection. The problem of self-consciousness as such arises. ${ }^{\text {T }}$

These are the issues of Cartesianism. The substance mind differs generically from the substance body; and the specific proof of this difference is seen in the opposition between the extended thing and the thinking self. And the thinking mind knows itself and sets itself over against all the objects of its thought.

Of Descartes' more detailed and special theories, that of "animal automatism" is the most significant. He rejected altogether the conception of an animal or vegetable soul different from the rational; and held that the organism was governed by the same physical and mathematical laws as other bodies in nature. The unreasoning animals are "automata," living machines. Man alone has the power of directing his movements.

x "In the intellectual life of Greece . . the complete severance of spirit and nature had not yet arrived: the subject had not yet reflected upon itself. . . . The turning of self-consciousness upon itself, which was the standpoint of the post-Aristotelian speculations, forms in Descartes the starting-point of a new philosophy."Schwegler, Hist. of Philos. in Epit., pp. 184-185. 
For the "image" theory of sense perception, Descartes substituted a mathematical conception finding the sense-stimulus in "vibratory" rays or undulations (light, air, etc.), expressed in mathematical formulas. These produce effects in the organism which are in no sense "like" the object perceived.

In his doctrine of emotion, Descartes comes to the verge of a psycho-physical theory, in spite of the difficulty of conceiving any interaction between the two disparate substances. He held that the heart, actuated by heat, due to its own processes of combustion, produces "animal spirits" or fluids (spiritus animales). These circulate through the body and affect the seat of the soul (the pineal gland in the brain). This results in sensations, perceptions, and emotions. The entire life of perception and feeling has this physical basis. Memory is due to the second or subsequent passage of the animal spirits reviving the spores or residua of their earlier action.

Thinking has its clear and evident principles, innate ideas-extension, number, duration, cxistence, etc.-given to the soul much as the immediate knowledge of the self is given to it. These are in contrast with the obscure and confused perceptions of sense. In this theory, the problems of the criteria of immediate certainty"clearness and distinctness," according to Descartes-and of the existence of "innate ideas" 


\section{Dualism, Rationalism, Dogmatism}

were brought into philosophy, to be bones of contention, the latter problem especially, to thinkers from Locke to Kant.

Under the term "thought," Descartes included all the operations of mind. He distinguished, however, between "passions" and "actions," I passive and active operations of mind. $\mathrm{He}$ called them "perceptions" and "volontés." The intelligence, no less than the feelings, considered as caused by the action of objects, comes under the heading of "passions."

The idea of God must be true, since no object save God could cause an idea of the infinite and perfect. Further, God is the guarantee of the validity of the clear and distinct ideas generally, since we cannot suppose he would deceive us. Thus the certainty of the object of knowledge rests upon the certainty of the existence of God.

In all the details, we find the tendency to clarify the conception of soul, by restricting its presence to those purer and more intellectual processes in which dependence upon physical states is not in evidence. This results in the passing over of the lower functions-sensation, feeling, movement-to the spatial and physical. Thus the dualism is sharpened between the one substance which thinks, and the other which is extended.

${ }^{\prime}$ Descartes, Les Passions de l'ame. 
II. Occasionalism and Pre-established Harmony.-The immediate result of the dualism of Descartes was to give further emphasis to the embarrassing psycho-physical relation. So urgent did the question of mind and body become that its answer was the burden of all the subsequent thought of the school.

In Occasionalism, the next step was taken. Geulincx and Malebranche distinguished between a "cause" and an "occasion." A cause is a real source of action, producing an effect which without it would not have been produced. An occasion, on the contrary, is merely the more or less accidental circumstance under which the true cause acts, or by which it is interfered with or prevented from acting. For example, the pulling of the trigger of a gun is the occasion of the expulsion of the ball; the cause is the exp osion of the powder.

Applying this distinction, the "occasionalists" said that the mind acted as occasion of the movements of the body, not as their true cause. Being disparate in character, will and body could not act causally upon each other. But the will could serve as occasion for the true cause, the action of God. Both sensation, which seems to be caused by the external object, and movement, which seems to be caused by the mind, are in reality caused by God.

This occasional relation of mind to body served 


\section{Dualism, Rationalism, Dogmatism I 39}

the human purpose of volition, but at the same time did not impair the divine truthfulness as embodied in the two clear and distinct ideas.

This view is represented to-day, in kind, in the theories which hold that while the mind cannot alter the energy of the brain in quantity, it can direct the discharge of this energy in one nervous course rather than another.

The superficiality of such a conception prevented its being more than a stepping-stone to the radical doctrine of "pre-established harmony." One may avail oneself directly of Descartes' suggestion as to the original effective act of God, rather than distribute the divine influence through a series of special acts. It is part of the original act of causation, one may say, that all possible cases of apparent interaction of matter and mind have been provided for. Whenever such a case appears, presenting concomitant changes in both mind and body, it is due to a "harmony" arranged for, prearranged, "pre-established," in the creation of each. Each changes because it is so made, not because the other changes. Each would change if, lacking such complete harmony, the other did not. It is inexorably arranged that my arm should move whenever my will exercises itself, and seems to move it, just as it is inevitable that two clocks, each regulated by the divine harmony of the spheres, should strike at the same instant, and seem to 
influence each other to do so. The two series of events, mental and physical, therefore, are quite independent of each other. There is no interaction whatever. The conditions under which Leibnitz developed this view further are noticed on another page below.

These doctrines, it is clear, did not affect psychology much beyond fixing the Cartesian points of view. Automatism is extended in theory to the human organism. The body moves independently of mind by a divine decree, which acts on occasion of a volition or which establishes once for all its harmony with volition. In either case, there is the explicit assumption of the act of God-a metaphysical principle, a deus ex machina, serving as first cause and prime mover of mind and body alike. This leads to a new dogmatism of method and a new absolutism of result in the schools of Wolff and Spinoza, which obscured the Cartesian light of immediate self-consciousness. The gulf was thus widened between the rationalist schools of the Continent and the empirical school in England.

In Malebrancne (I638-I7I5), however, we find the development of the doctrine of occasional causes into a general idealistic theory of knowledge. The soul, says he, cannot know things themselves: things are only the occasion of the rise of ideas in the mind. The true cause of all 


\section{Dualism, Rationalism, Dogmatism I4I}

ideas is God, in whose presence and action the world is perceived. Even the ideas of the perfect and infinite cannot be innate to the soul, for it is finite and imperfect. These ideas-that of God himself-are divinely aroused in the mind on the occasion of the contemplation of the world with attention. Hence the saying of Malebranche, "We see all things in God." Actions, moreover, acts of will, are volitions of God, since our desire is only their occasional, not their original, cause. The active life, like the intellectual, is lived in God.

In this we find a return to the Platonic "idea," with a commingling of Neo-Platonic mysticism. In so far it abandons the point of view of empirical conscious process, and prepares the way for the theory of the identity of mind and body in the absolute, as announced by Spinoza. Yet in one important point Malebranche was a dualist, not an absolute idealist: he held that the knowledge of the soul through self-consciouness was more superficial than that of the body. We have a profound knowledge, in his view, of space and its properties-the essence of matter; but we know only particular states of mind, not general and universal truths. God, therefore, is rather a postulate of logical and theological value, not a principle capable of unifying the terms of the mind-body dualism.

Malebranche showed himself, indeed, to be 
a first-rate psychological observer. He investigated vision with notable results; working out a vibration theory of colour differences, a theory of accommodation, an account of visual depthperception. He was led also into the investigation of sense-illusion by the objection raised to his occasionalist view, to the effect that God often deceived us in these cases.

Spinoza.-In Baruch de Spinoza (1632-1677), one of the heroic figures of philosophy, the dualistic theory received its final philosophical statement-final, that is, in the sense that to go beyond the Spinozistic formulation is to merge the two terms in an identity so unifying that their differences disappear altogether.

Spinoza employed a deductive and mathematical method. His great work, Ethica, ${ }^{\mathbf{x}}$ consists of a series of propositions and demonstrations, with corollaries drawn out in the manner of geometry. In his opinion neutrality and objectivity, no less than mathematical validity, were thus given to the conclusions reached.

Admitting the truth of the distinction between mind and matter, and that of the impossibility of any interaction between them, there is, said Spinoza, one other truth equally indisputable:

${ }^{x}$ Ethica ordine geometrico demonstrata. Trans. and introduction by Sir F. Pollock, Spinoza, his Life and Philosophy, 2nd ed., I 899 . 


\section{Dualism, Rationalism, Dogmatism I43}

the changes, relations, and events taking place in them occur in strict correlation: "the order and connection of ideas is the same as the order and connection of things"-ordo et connexio idearum idem est ordo et connexio rerum. How is this possible-assuming the truth of the dualism already agreed to?

It is possible, said Spinoza, in formal agreement with Malebranche and Geulincx, only because of the presence of the activity of God in both. But how is this presence to be conceived? Here the thought of Spinoza takes form in a system of absolute formal identity.

God is the only, the one, substance; but being infinite, God must have an infinity of attributes. Nothing conceivable can be denied of him. Of this infinity of attributes, we are able to know only two: thought and extension, mind and matter; but the infinity-less-two attributes must have equal reality. Mind and body, therefore, are equally independent of each other and of all the other attributes, but they are also equally dependent upon the one infinite substance, God.

Whatever takes place in one of the attributes, say a thought in the attribute mind, or a movement in the attribute body, must have a corresponding place in each of the other attributes, since it is a modification of the one substance, God. The mode of thought- "mode" is Spinoza's term for any specific determination within 
an attribute-must have a corresponding spatial mode; and each mode of movement, a corresponding thought mode. Thus the correlation is established. Every event in thought or extension is also an event in extension or thought.

What, then, is this one substance? Only the sum of its attributes: more we cannot say. It cannot be defined by the predicates of thought; for "all definition is negation." I To affirm one predicate is to deny its opposite, and nothing can be denied of the infinite substance. To make it mind, would be to deny its attribute matter; and so on for all the unknown attributes. This is the explicit declaration of Spinoza, whose system is refractory to any interpretation in a subjective or idealistic sense. ${ }^{2}$

The formal logical requirement of identity has its proof in the actual existence of the correlated modes in the attributes of thought and extension.

The emphasis is thrown back upon the attributes, upon the realistic and dualistic happenings of the life of thought in the world of extension.

I Determinatio est negatio, Epistle 50.

${ }^{2}$ This is in opposition to some commentators, as Pollock, who find a tendency in the attribute thought to "swallow up all the other attributes," based upon Spinoza's Definition 4 of Attribute ("that which intellect perceives concerning substance," cf. also Epistle 27). A refutation of this view with citation of texts is to be found in the writer's paper, "The Idealism of Spinoza," Fragments in Philosophy and Science, Chap. II. 


\section{Dualism, Rationalism, Dogmatism 145}

Even will and intelligence do not exist in God: they are modes merely in the finite attribute, mind. Spinoza's flight of speculation justifies the existing order, and makes it possible to pursue the sciences, physiology and psychology, without embarrassment from the problem of interaction. It is a metaphysical anticipation of the forms of truce established in the development of science-the theory of "parallelism," the "double-aspect theory," etc.- - which banish the problem of cause as between mental and physical phenomena, and confine attention to the facts in the two domains respectively. While, therefore, Spinoza could not join the Positivist camp-he was one of the archmetaphysicians in the eye of Comte-still, we may say that in his doctrine of identity the absolute becomes so tenuous, characterless, and harmless that science may entirely ignore it. The natura naturans shows itself only in the natura naturata, as Spinoza puts it-absolute nature appears only in phenomenal nature.

Spinoza was also a psychologist. He distinguished, in the traditional way, the stages of intellectual apprehension-imagination, intellect, intuition. He found it difficult to carry out a theory of general knowledge and abstract intuition, in the face of his doctrine of concomitant modes of mind and body; since the physical mode must correspond to the object of thought 
and also to the modification of the self. But this difficulty loses some of its force when we realise that the physiological event accompanying a general idea or the general self need not itself be "general"; it need only be specific. One brain modification may correspond both to the thinker and to the object of his thought.

The active life was to Spinoza the development of a fundamental "will to live," a tendency (conatus) toward self-conservation. Immortality was upheld by a curious argument ad hoc, in effect this: the personal soul is not the highest or true soul by which thought is manifested. There is a higher and purer mode than this, and with it there is associated another mode of body. At death this latter, the truer body, accompanies the immortal soul in accordance with the principle of the concomitance of the modes.

Leibnitz (1646-1716). - As mathematician and philosopher, Leibnitz is classed among the greatest geniuses, by reason of the comprehensiveness of his powers. He has been called the Aristotle of modern times. His views are fundamentally metaphysical, since he starts out from the conception of substance. But in consciousness he finds the character of substance. Mind is the explaining principle of all reality. Leibnitz is at once a monist and a pluralist: a monist so far as qualitative distinctions of substance are concerned; he accepted only one 


\section{Dualism, Rationalism, Dogmatism 147}

substance, the soul: a pluralist so far as independent centres of existence or reality are concerned; there are many independent souls, irreducible "monads."

It is among these independent monads or soulatoms, ${ }^{\mathbf{I}}$ each conscious, that the pre-established harmony of the world shows itself. The body is an aggregate of monads, in essence souls. There is no matter as such: only the spiritual monads exist. These aggregates range from the inorganic, through plants and animals, up to man. In the aggregates higher than the inorganic there is a central monad or soul, which in appearance rules the rest; but the law of the relation is that of pre-established harmony.

The monad or spiritual atom is self-active, never passive. Its essence, as shown in consciousness, is activity of "presentation," taking form in will and thought. This one activity or mental energy shows itself continuously in all the development of the mind, beginning with the "dark" or unconscious presentations present even in the inorganic world, and ending with the "clear" analytic thought of human reason. In its nature this activity is both distinguishing and relating. The elements unconsciously present in the "dark" presentations of the lower orders of monads, are brought out in the rela-

' Leibnitz worked out a systematic theory of the monads, calling it "monadology." 
tional form of thought in the higher. And in the development of the individual mind, progress consists in this advance from unconscious complexity to conscious relation. In it all, the specific character of consciousness, and that of all reality, is "unity in variety" - variety of elements in the unity of the one conscious activity. The highest stage involves not only clear relations of elements, but also consciousness of self as the active unity. To this Leibnitz gave the name of "apperception," in contrast to the mere "perception" of the lower stages.

The entire progression from lower and obscure to higher and clear knowledge is native to the soul; it all belongs to its original power of presentation. To the statement of the sensationalists to the effect that there is nothing in reason that was not already present in sense, Leibnitz replies, "except reason itself," nisi ipse intellectus.

The synthetic character of Leibnitz's views, thus briefly described, becomes at once apparent. He held to a monism of substance, thus making the harmony of world-activities possible: each of the monads "presents" or reflects all the others; it is a mirror of the world, a "microcosm." But he established a pluralism of individualities, differences among the particular centres of reality, as it had never been done before. The character of the soul as a unitary energy or activity is not lost either in its qualitative same- 


\section{Dualism, Rationalism, Dogmatism 149}

ness with other souls, or in the differentiation of presentations within its own thought. The fruitful but much overworked principle of modern speculativeidealism, "identity in difference," had here its earliest and perhaps its soundest exposition. In this connection, the principle of "sameness of indiscernibles" was formulated and applied: the proposition that without real differences, only abstract identity of apprehension is possible. For perception indistinguishable things are identical. ${ }^{\mathbf{I}}$

In the theory of the one activity or energy, spiritual in character, pan-psychism is revived; but in a form that emphasises individuality. A "social" character, so to describe it, is introduced into the structure of the world. The difficulty, indeed, with Leibnitz's pluralism would seem to lie on the side of its insufficient unity. The monads lack essential and immanent bonds of union. Their systems of presentations merely duplicate one another. And the doctrine of God, the supreme monad and cause of the unity of the world, remains obscure. Leibnitz further incorporates in his system the genetic and vitalistic points of view of Aristotle, interpreting life, however, in terms of mind, rather than the reverse. In this connection, his theory of unconscious

"The correlated principle of " difference of discernibles" is equally true: one thing becomes two or many when differences of appearance prevent its identification (see the writer's Thought and Things, Vol. II, Chap. XIV, §8). 
presentations, petites perceptions, which have the power of developing into conscious cognitions, is based upon sound observation. Certain of his special arguments, however, drawn from the composition of colours, sleep, and the summation of infinitesimally small stimulations, are of very unequal value. They are all used, in varying forms, and variously criticised in later literature of the "unconscious." It was in Leibnitz, as Harms remarks, that the series of explanations of the clear by the obscure, the positive by the negative, the conscious by the unconscious began. It reached its culmination in Schopenhauer and Hartmann, and remains the resort of many pseudo-explanations-from crime to genius; from art and invention to hysteria; from sexual manifestations to religionin the psychology of to-day. By making consciousness unconscious, whenever other explanations fail, of course one enlarges one's resources.

Finally, it is to be noted that the form given by Leibnitz to the postulate of self-consciousness - making it active in its very nature-asserts a positive spiritualism as over against the passivism found in the empirical psychology of the British school. ${ }^{\mathrm{I}}$ The mind is not a tabula rasa,

${ }^{1}$ The title of Leibnitz's New Essays on the Human Understanding (Nouveaux essais sur l'entendement humain) has reference to that of Locke's Essay concerning HumanUnderstanding. 


\section{Dualism, Rationalism, Dogmatism I5I}

a blank tablet, receiving impressions from outside itself; it is, on the contrary, the fons et origo of all action. The will is the principle by which the flow of presentations in consciousness takes its determined course; it is the dynamic aspect of mind.

In short, we find in Leibnitz's psychology a synthesis of elements drawn from Aristotle, the Stoics, and St. Augustine; the whole recast in the form made possible by the development of the dualistic motives in and after Descartes. It has left an indelible mark upon modern thought. In view of its metaphysical point of departure, and its explanation of the world in terms of mind, we may consider it as the culmination of the rationalism of Descartes and Spinoza. With reference to later developments, we may note that it lacks the radical distinction between intellect and will which marked and differentiated the systems of subsequent idealistic thought.

Dogmatism.-Christian Wolff (died I754) defined the doctrines of Leibnitz, each for itself, in such a way that they lost their relation to the system as a whole. They became a series of dogmatic statements. His method, moreover, was ultra-logical, proceeding by definition and distinction. The "monad" became the "atom" again. The power of "presentation" was restricted to the mental or conscious atoms. Preestablished harmony took the form of an order 
established once for all by the act of God. There was no possible direct interaction between mind and matter.

The activity of the soul, described as in itself one, takes on, according to Wolff, different directions, appearing in different "faculties," of which the vis repraesentativa, or "logicalfaculty," is fundamental. The active faculty or will is due to the same fundamental movement. The faculty of imagination, belonging to knowledge in general, produces representations connected by the law of association in the form of statement that a partial reproduction revives the whole of which it was formerly a part. $^{\mathrm{r}}$

Wolff distinguishes memory, poetic fancy, etc. -faculties arranged in order and treated with much psychological insight. The emotions are mixtures of pleasure and pain, which reflect respectively the relative clearness or obscurity with which unity in variety appears in the mental life.

Although dogmatic and unoriginal in his philosophy, Wolff undoubtedly aided the progress of psychology; principally, however, by sharpening its problems. The suggestion of "faculties" soon crystallised in the extravagant "faculty psychology" which cut the mind up

"This anticipates the "Law of Redintegration" formulated by Sir William Hamilton. 


\section{Dualism, Rationalism, Dogmatism I53}

into water-tight compartments, each doing its peculiar work in independence of the others. ${ }^{\text {I }}$

The distinction made by Wolff between a "rational" or philosophical, and an "empirical" or observational, psychology was in line with a later division of problems and interests; but his books on these two sorts of psychology ${ }^{2}$ illustrate the difficulty of carrying out the distinction from his point of view. To him "rational psychology" was a deductive metaphysical discipline, over against the inductive and empirical science. The former should rather have been called the "psychology of rationalism."

His distinction between the two is not that which modern psychology recognises in differentiating between the observational problem with which science begins, on the one hand, and the explanatory problem, on the other hand, with which she concludes. This latter distinction was developing in a sounder way in the work of the British Empiricists.

The movement traced in this chapter-from Descartes to Wolff-shows the development of one of the great motives of reflection: that which exhibits, in philosophical and reasoned form,

"An historical review of the doctrine of "faculties" is given by Klemm, loc. cit., pp. 44-70; and in Dessoir, loc. cit., is to be found a section on the "German Faculty Psychology following Wolff."

"Empirische Psychologie and Rationelle Psychologie. 
a rational solution of the problem presented by the sharp Cartesian dualism of mind and body. In the different theories, having this motive in common, the alternatives re-occur which came forward, in less reflective form, in Greek and Mediæval thought. In succession we see bare and barren dualism in Descartes, "creationism" in Nalebranche, "absolute idealism" and "identity" in Spinoza, psychic "atomism" and "panpsychism" in Leibnitz. They all employ the postulate of rational certainty as attaching to knowledge, and follow a deductive method. They all identify the rational principle with God. It will be profitable, before going further, to make these points a little clearer.

The dualism of Descartes was more "bare and barren" than that reached at any time by tine Greeks, because it was more conscious and uncompromising. The last ambiguity of matter, as well as the last embarrassment of mind, was removed; the divorce of interests was complete. The extent of the damage suffered by psychology is scen in the automaton theory by which all possible vital connections between soul and body were denied. The theory of naturalism was extended, it is true, but entirely in the sense of enlarging the sphere of the physical. The psychical, beyond being defined as "thought," was placed more than ever beyond the reach of positive method. 


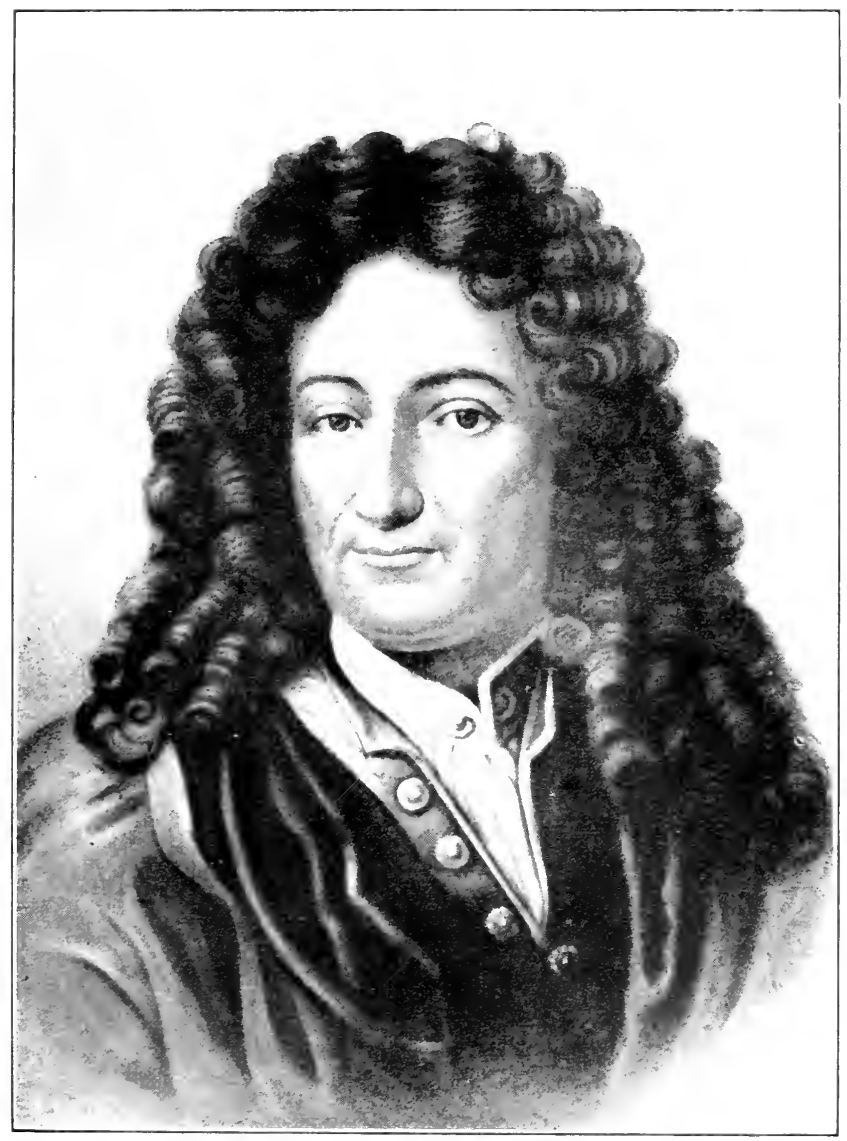

Gottfried Wilheli voy Leibitity.

(Copyright. Reproduced by kind permission of the ()pen Court Publishing (1), (hicago, U.S.A.) 



\section{Dualism, Rationalism, Dogmatism I 55}

The solution offered by any sort of creationism, as in the Church Fathers and Malebranche, only made the issue more obscure by setting a term to investigation. To say "the world is made of nothing" simply means that God is its cause in every sense, material and formal alike. The tendency then becomes-as it showed itself in the Greeks - to make of "nothing" a sort of negative "something" upon which God could act and out of which the world could take form. The "non-being" of the Greeks became a negative something against which the positive divine impulse asserted itself. This was developed in the post-Kantian idealism on lines laid down by Boehme.

The new departures found in Spinoza and Leibnitz show an interesting contrast. The one "cuts under" the dualism of thought and extension, leaving its superficies intact, just as we put a cellar under a house! God is the unifying principle, the foundation-stone on which both pillars of this structure of reality rest. Our separation of the parts, the attributes, obscures our vision of the whole, the substance. There is but one substance.

To Leibnitz this division of reality into two substances is equally superficial; but his way of surmounting it is the very opposite to that of Spinoza. He reaches one substance, but makes it pluralistic, atomistic, in its properties. Instead 
of an infinite attribute we find an infinitely small soul-monad. And by cutting up the substance thought into an infinite number of bits, the substance extension is made to disappear.

For psychology the main thing was the continued importance attached to intellect, reason; this part of Cartesianism was not outgrown. Reason was the thing to account for and reason was the instrument by which to account for it.

Empiricism. - Another great current of thought was gathering force across the Channel; moving in a direction opposed to "Rationalism," and known as "Empiricism."

In Gassendi and Hobbes the empirical tendencies of the Pre-Cartesians, Vives and Roger Bacon, focused themselves. As in Descartes a series of rationalistic theories took their rise, so in Gassendi and Hobbes-who directly opposed Descartes personally - the naturalistic and materialistic series began. The dualistic-idealistic philosophy was opposed by the monisticsensationalistic. Gassendi (I592-I655) developed the atomism of Epicurus, but admitted the possibility of a sort of soul-molecule in the primitive matter. He also made reason the function of a special immaterial soul created, as the atoms were, by God.

It was by Hobbes (1588-1679) that the two fundamental positions of Cartesianism were 


\section{Dualism, Rationalism, Dogmatism I 57}

alike assailed: the substance view of mind and the rational theory of the origin of knowledge. Mind, said Hobbes, is a function of body, and reason is a product of sensation. The world is made up of matter in motion under mathematical laws; and consciousness is one of the aspects or characters of the living organism. There is, then, no separate substantive soul or spirit as the dualists declare.

Further, sensation is the one conscious event, and upon it knowledge is founded. Sensation is based upon physiological processes, stirred up by external stimulation. Hobbes describes these organic processes, making the heart the centre.

By the compounding of sensations-the process so greatly developed by later sensationalists and associationists-all the modes of intelligence are produced. With sensation goes an original form of impulse-identified with the preservation of life-and also feelings of pleasure and pain. These, like the sensations, are compounded under the laws of association. The whole results in a conception thoroughly naturalistic and mechanical in spirit, but its carrying out is inadequate and sketchy. It served as programme, however, for the later more detailed attacks upon rationalism, which carried the warfare into the special fields of innate ideas and the theory of knowledge. 
The verve of Hobbes's philosophy was directed toward political theory; and in this he established the bond between sensationalism and political individualism, which remained vital and persistent during the development of eighteenth-century British thought. ${ }^{\mathrm{P}}$

"This showed itself in the union of philosophy and "civil polity" in the chairs of instruction in the universities. In T. H. Green at Oxford, and H. Sidgwick at Cambridge, in the last quarter of the nineteenth century, the two interests still showed themselves closely united. 


\section{INDEX TO VOLUME I}

(The figures printed in heavy type indicate the most important citations.)

\section{A}

Absolute, of Plotinus and Aristotle, 90

Achilles, argument, $5^{\circ}$

Adamson, R., I 2 I

Esthetic contemplation, in Plato, 68; Aristotle's, I

Albertus Magnus, IOI, $104 \mathrm{f}$.

Alexandrian philosophy, 39

Alhacen, I I I

Analogy between race and individual, Introduction, 88, $126 \mathrm{f}$.

Anaxagoras, 30, $35 \mathrm{ff} ., 44,60$

Anaximander, $35 \mathrm{f} ., 42$

Anaximenes, $33 \mathrm{f}$.

Animism, I9

Anselm, argument, Io9

Antisthenes, 70

Apperception, to Leibnitz, I48

Aquinas, Thomas, I02, $104 \mathrm{ff}$.

Arabian Psychologists, I Io ff.

Aristippus, 70

Aristotle, 41, $72 \mathrm{ff}$; on matter and form, 73, 82; dualism

of, 73 ; on the soul, 74,75 ; on physies, 74 ; on cognitive powers, $77 \mathrm{f}$.; on categories, 79 ; on virtue, $8 \mathrm{I}$; on motive powers, 79, 80; on æsthetics, 8I

Arminianism, 109

Art. See Asthetics and Pancalism.

Association of ideas, Aristotle on, 78; in Wolff, 152; in

Hobbes, I 57

Atomism. See Atomists.

Atomists, 3I, 40; Greek, 42 ff.; Gassendi, I 56 
Attribute, of Spinoza, I43 f.

Automatism, in Descartes, I35

Averroēs, I I I $\mathrm{f}$.

Avicenna, I Io

B

Bacon, F., II 8 , I2I

Bacon, Roger, I I I , I20, 156

Bain, A., I I 9

Beneke, I I9

Benn, A. W., 33, 42, 43

Berkeley, i 16

Boas, F., 23

Boehme, Jacob, I 24 f., I 55

Boutroux, E., 58, 90, I24

Bruno, Giordano, 120, 122

Caird, E., $83 \mathrm{f}$.

Calvinism, I09

Campanella, I20, 122

Carneades, 87

Carpenter, J. E., 9I

Cartesianism, 38

Cause, four sorts, of Aristotle, $73 \mathrm{f}$.

Chance, Stoic, 86

Christian Ethics, $94 \mathrm{f}$.

Classification, of sciences, Bacon's, I22; of functions, I22

Clearness and Distinctness of Descartes, I 36

Cogito ergo sum, of Descartes, I34

Collective representation, 2 I, 22

Common sense in Aristotle, $78 \mathrm{f}$.; to the Stoics, 86

Comte, i i 8; law of three stages, i6

Conatus, of Spinoza, I 46

Concurrence of Interpretations, $7 \mathrm{ff}$.

Condillac, I I 7

Consciousness, to the Eleatics, 49 ; to the Stoics, 85

Contemplation, in Plato, 68

Corpuscular theory, $32,42 \mathrm{ff}$.

Creationism, 96; of Albertus, 105; to Duns Scotus, 107

Cyrenaics, 70

Cynics, 70

Darwin, Ch., I I9

De a nima, of Aristotle, 29 


\section{Index}

Descartes, 50, 98, IOI, II4, I20, I24 f., I3I ff.; motto of, I32; automatism in, I35; superception, I36, I 54

Dessoir, Preface, IO, 54, I 53

Democritus, $42 \mathrm{f}$.

Demons, 44

Determinism, ethical, of Socrates, $59 \mathrm{ff}$.

Diderot, I 17

Difference of Discernibles, I49

Diogenes of Apollonia, $33 \mathrm{f}$.

Diogenes the Cynic, 70

Dogmatism, I5I $\mathrm{f}$.

Doubt, of Descartes, I33

Dunamis, in Aristotle, 74

Duns Scotus, I02, $107 \mathrm{f}$., 120

Dualism, origin and development of, 29 ff.; Aristotle's, 73; to St. Augustine, I Oo; interpretation, 94 ff., I $44 \mathrm{ff}$; of Descartes, I3 I f., I54

Dualists, early, $35 \mathrm{ff}$.

Durkheim, E., 2 I

E

Eckhart, Meister, II2 f.

Ecstasy, of Neo-Platonism, 88

Ejective process, 65

Eleatics, $30 \mathrm{f.}, 47 \mathrm{ff}$.

Elements, chief, $35 \mathrm{f}$.

Emanation, of Neo-Platonists, 88; of Plotinus, 89

Emotion (see Feelings); in Descartes, 136

Empedocles, 35 f., 44

Empirical or Positive Psychology, $120 \mathrm{ff}$.

Endowment, mental, $24 \mathrm{ff}$.

Entelechy in Aristotle, 74

Epictetus, 84

Epicurus and Epicureans, 83 ff., I 56

Espinas, A., 21

Ethics (see Virtue and Good); Stoic, 86; Christian, 85, $94 \mathrm{f}$.

Euclid of Megara, 70

Evolution to the Ionics, 33, 34, 75; in Aristotle, 74

Extension of Descartes, I3 I

Faculties (see Functions and Powers); to Wolff, 152 Fatherhood of God, 94

VOL. 1.-II 
Feelings (see Powers, Faculties, and Functions); St. Augustine on, 97; to Descartes, I37

Fichte, II 6

Final Cause, to Socrates, 60

Folk-psychology, 20

Form and matter in Aristotle, 73, 82; in St. Thomas, 105 Fouillée, A., $60 \mathrm{f}$.

Fowler, T., I22

Frazer, J. G., I9

Freedom of will, to Duns Scotus, I07

Functions, Mental Powers; to St. Augustine, 97; to St.

Victor, I02; to John of Salisbury, I04; Classification of, Bacon's, I22; to Spinoza, I 45

Furry, W. D., 70

\section{G}

Galileo, I20

Gassendi, 156

Gemüth, II

Genetic point of view, in Aristotle, $75 \mathrm{f}$; ; in John of Salisbury, 104; Psychology, I 19

Geulincx, I +3

God, to Plato, 63 f.; to Aristotle, 73 ; to Plotinus, 89; Fatherhood of, 94 ; to Boehme, I24 f.; to Malebranche, I 4 ; t to Spinoza, I 49; to Leibnitz, I43

Golden Rule, $9+$

Gomperz, 33

Good, the, to Plato, 63

Gorgias, 52

Greek Period, Io; of speculation, Ist period, 29 ff.; Psychology, $32 \mathrm{ff}$.; Mystics, $87 \mathrm{f}$.

Green, T. H., I 58

$\mathrm{H}$

Hammond, 79

Harms, Preface, 59, 89, 92, 99, 125

Hartley, I I 7

Hartmann, E. von, I 50

Hate, and Love, of Empedocles, $40 \mathrm{f}$.

Hegel, I 7, I 16, I26

Helmholtz, H., I I I

Herbart, I 19

Hobbes, I $17,156 \mathrm{f}$. 


\section{Index}

Hodgson, S., II9

Höffding, 16

Homo mensura omnium of the Sophists, 52

Hippias, 52

Hume, I 19

Hylozoism, Ionian, 32, 33 ff.

\section{I}

Ideas, Plato's theory of, $6_{3} \mathrm{ff}$.

Identity, philosophy of Spinoza, I $43 \mathrm{ff}$.

Imagination, Aristotelian, 78; in John of Salisbury, IO4; to Italian Mystics, $123 \mathrm{f}$.

Indian systems, $9 \mathrm{I}$

Individual and Racial Thought, I ff.

Intellectualism, i $6 \mathrm{f}$.

Interpretation, Prehistoric, Io; prelogical, Io; unscientific, $29 \mathrm{ff}$; of dualism, I I $4 \mathrm{ff}$.

Ionians, $30 \mathrm{f}$; hylozoism of, 32

J

James, W., I I9

Jesus, $94 \mathrm{f}$.

John of Salisbury, I04 f., I20

Judgment (see Powers, Functions, Scholastics); to John of Salisbury, I04

$\mathrm{K}$

Kant, 69, I 16, I23

Kepler, 120

Klemm, O., Preface, 54, I I I, I 53

Knowledge (see Perception); Aristotle's theory, $77 \mathrm{f}$.

L

Lange, 42

Leibnitz, i 16 , I46 ff.; $154 \mathrm{f}$.

Leucippus, $42 \mathrm{f}$.

Lévy-Bruhl, I 8, 20, 22

Localisation, cerebral, by Avicenna, I Io

Locke, II 9

Logical, and pre-logical thought, $8 \mathrm{f}$.

Logos, 86 
Lotze, H., II 9

Love, and hate, of Empedocles, $4^{\circ}$

Love, divine, of Plato, 69; of Neo-Platonism, 88; of Plotinus, 90, $9 \mathrm{I}$

Lucretius, 84

\section{M}

Nalebranche, II6, I40 f., I43, $154 \mathrm{f}$.

Marcus Aurelius, 84

Materialism of Epicurus, $83 \mathrm{f}$;; of Hobbes, 156

Matter $(\dot{v} \lambda \eta), 38$; to Plato, 66

Natter and Form, in Aristotle, 73, 82; in St. Thomas, 105

Mechanics, of Ideas, I2 I

Nediæval period, II

Mediation, processes of, 59

Megarics, 70

Memory (see Powers, Faculties, and Functions); to St. Augustine, 97 ; to Plato, 67

Metaphysics, Aristotle's, 74

Method, scientific, of Bacon, I2I f.

Mill, J., I I 9

Mill, J. S., I I 8

Modern period, i $\mathrm{r}$

Monadology of Leibnitz, 147

Motive Powers, Aristotle on, 80

Multiplicity to the Eleatics, 48

Mysticism, Greek, $87 \mathrm{ff}$.; in Plotinus, $90 \mathrm{f}$; German, II2 f., Italian, $122 \mathrm{f}$; ; Christian, 125

$\mathrm{N}$

Nature, concept of, 45

Nemesius, 99

Neo-Platonism, $87 \mathrm{ff}$.

Neo-Platonists, 70

New Academy, 87

Newton, I2 I

Nominalism, I03, 106

Nous ( $\nu$ oûs), of Anaxagoras, $39 \mathrm{ff}$.

Number, Pythagorean, $45 \mathrm{f}$.

Objectivism, 72 ff.

Occasionalism, 138 ff. 


\section{Index}

Optics, of Alhacen, I I f.; Kepler, 120; Malebranche, I42 Orpheus, 46

Orphic mysteries, 28, 46

\section{$P$}

Pancalism in Plato, 69; in Aristotle, 81

Paracelsus, I 22

Paradox, Socratic, 6I

Parmenides, 39, $47 \mathrm{f}$.

Participation, law of, 22 .

Passion, of Descartes, I 37

Patristics, $93 \mathrm{ff}$.

Paul, the Apostle, 39

Perception, to Empedocles, $4 \mathrm{I}$; to Democritus, 44 ; to the Eleatics, 48,49 ; to Descartes, I36; to Leibnitz, I48

Periods of interpretation, Io ff.

Person, conscious, of Neo-Platonism, $87 \mathrm{f}$; ; of Philo, 88; to St. Thomas, I06

Philo (Judæus), of Alexandria, 88

Physiological Psychology, Arabian, ir Io ff.

Plato, on Socrates, 61, 62 ff.; on the Good, 63; on the Soul, $66 \mathrm{f}$; on reminiscence, $67 \mathrm{f}$.; love, 68 ; contemplation in, 69

Plotinus, $87 \mathrm{ff}$., I $24 \mathrm{f}$.

Pollock, F., I 42 f.

Post-Aristotelian Schools, $83 \mathrm{ff}$.

Powers of Mind (see Faculties and Functions); Aristotle on, 77; St. Augustine on, 97

Pre-established harmony, I38 ff.

Prehistoric interpretation, IO

Primitive thought, I3 ff.

Prodicus, 52

Projective period, 29 ff., 55

Protagoras, $30,5^{2}$

Psychology (see Interpretation); as Physics, 67; physiological, Arabian, I Io ff.; modern, I I4 f.; philosophical, II7 f., I3 I ff.; empirical and positive, I20 ff.; rational and empirical, 153

Psycho-physics, of the Arabians, I I2; Aristotle's, 77

Psychosophy, i $3 \mathrm{ff}$.

Pythagoras (and Pythagoreans), 3I, $45 \mathrm{ff}$.

\section{$\mathrm{R}$}

Racial and individual thought, $\mathrm{I}$ ff. Realism (logical), I03 f., I06 
Reality, in Plato's "ideas," $63 \mathrm{f}$.

Reason, to Aristotle, $74 \mathrm{f}$.

Reflective period, I I

Relativity to the Sophists, $5 \mathrm{I}$; to Carneades, $87 \mathrm{f}$.

Reminiscence, of Plato, 67

Ribot, II 9

Romanes, II 9

Rousseau, I 18

S

Saint Augustine, 96 ff., I 34

St. John, Logos doctrine, 88

St. Paul, 99

St. Victor, John and Richard of, 102

Sameness of Indiscernibles (Leibnitz), 149

Schelling, I 6

Schematism, Kant's, I 23

Scholastics, ror ff.

Schopenhauer, i 6 , I 50

Schwegler, I25, I 35

Science and vitalism, 83

Self-consciousness, to St. Augustine, 97

Seneca, 84

Sensation, Aristotle on, 78; Epicurus on, 84; John of Salisbury on, 104

Sensationalism in Epicurus, 84

Sermon on the Mount, 85, 94

Shanahan, E. T., 93

Sidgwick, H., I 58

Siebeck, 102, 108

Socrates, Preface, 29, 4I, 57 ff.; paradox of, 61 ; motto of, IOI

Socratic Schools, 54, 70

Sophists, 3 I f., 45

Soul, Plato on, $68 \mathrm{f}$.; Aristotle on, $74 \mathrm{f}$; Stoics on, $70 \mathrm{f}$.;

Plotinus on, 89; Christian doctrine of, $95 \mathrm{f}$.; to St.

Thomas, 105

Space perception, Alhacen on, II I

Spencer, H., I I 9

Spinoza, 50, I 16, I25, I40, $142 \mathrm{ff} ., 154 \mathrm{f}$.

Spirit (see Soul); to Anaxagoras, $37 \mathrm{ff}$; to Plotinus, 89; to the Fathers, 95

Spiritualism of the Fathers, $95 \mathrm{f}$.

Stagirite, see Aristotle. 
Steiner, R., 123

Steinthal, 20

Stewart, J. A., 69

Stoics, $84 \mathrm{ff}$.; ethics of, 85 ; on the soul, $85 \mathrm{f}$.; on Chance, 86 Subject, and object, in Boehme, I24

Subjectivism, of Socrates, 32; beginning in Empedocles, 39; the Sophists, $52 \mathrm{ff}$., $56 \mathrm{ff}$.

Substance, of Descartes, I3 I f.; of Spinoza, I43

Substantive period, I I

Suggestion, in Duns Scotus, 107

\section{$\mathrm{T}$}

Taine, r19

Tauler, John, II3

Telesius, I 22

Tertullian, 99

Thales, $33 \mathrm{f}$.

Thought, Radical and Individual, I ff.; primitive, I3 ff.; pre-logical and logical, I $8 \mathrm{f.}$; to Descartes, I3I; to Aristotle, $78 \mathrm{f}$.; see Logic.

Traducianism, 96

Transmigration of souls, 40, 46; to Plato, 66

Truth, to the Sophists, 53; to Socrates, 57; to Empedocles, $4 \mathrm{I}$

Tylor, E. B., I9

U

Unconscious judgments, of Alhacen, I I I ; in Leibnitz, I 50 Unscientific Period, Io; interpretations, 29 ff.

\section{V}

Verulam, Lord, see Bacon, F.

Virtue, to Socrates, $5^{8}$

Vision, see Optics

Vitalism, see Hylozoism, in Aristotle, 74, 82; of St. Thomas, I05

Vives, Ludovicus, I21, I56

Volens sum, of St. Augustine, 134

Voluntarism, 116

Waitz, 20

Wallace, A. R., II9 
Will (see Reason, Faculties, and Functions); to St. Augustine, 97; to Duns Scotus, 107

William of Occam, 108, 120

Wolff, I I6, I40, I5I f.

Word, see Logos.

World-soul, of Plotinus, 90

Wundt, W., 20

$\mathrm{X}$

Xenophanes, $\mathbf{4 7} \mathrm{ff}$.

Z

Zeller, E., 58

Zeno, the Eleatic, 48

Zeno, the Stoic, $84 \mathrm{f}$. 
A Selection from the Catalogue of

G. P. PUTNAM'S SONS

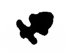

Complete Catalogue sent on application 


\section{A History of the Sciences}

Tा Hitherto there have been few, if any, really popular works touching the historical growth of the various great branches of knowledge. The ordinary primer leaves unexploited the deep human interest which belongs to the sciences as contributing to progress and civilization, and calling into play the faculties of many of the finest minds. Something more attractive is wanted.

T The above need in literature has now been met. Each volume in the History of Sciences is written by an expert in the given subject, and by one who has studied the history as well as the conclusions of his own branch of science. The monographs deal briefly with the myths or fallacies which preceded the development of the given science, or include biographical data of the great discoverers. Consideration is given to the social and political conditions and to the attitudes of rulers

\section{G. P. Putnam's Sons}




\section{A History of the Sciences}

and statesmen in furthering or in hindering the progress of the given science. The volumes record the important practical application of the given science to the arts and life of civilized mankind, and also contain a carefully-edited bibliography of the subject. Each volume contains from twelve to sixteen carefully-prepared illustrations, including portraits of celebrated discoverers, many from originals not hitherto reproduced, and explanatory views and diagrams. The series as planned should cover in outline the whole sphere of human knowledge.

T) Science is to be viewed as a product of human endeavor and mental discipline, rather than taken in its purely objective reference to facts. The essential purpose has been to present as far as practicable the historical origins of important discoveries, also to indicate the practical utility of the sciences to human life.

\section{G. P. Putnam's Sons}

New York

London 


\section{A History of the Sciences}

Each volume is adequately illustrated, attractively printed, and substantially bound.

I6mo. Each, net, 75 cents. By mail, 85 cents.

\section{History of Astronomy}

By George Forbes, M.A., F.R.S., M.Inst.C.E.

Formerly Professor of Natural Philosophy, Anderson's College, Glasgow

\section{I2 Illustrations}

I thank you for the copy of Forbes's History of Astronomy received. I have run it over, and think it very good indeed. The plan seems excellent, and I would say the same of your general plan of a series of brief histories of the various branches of scienee. The time appears to be ripe for such a series, and if all the contributions are as good as Prof. Forbes's, the book will deserve a wide circulation, and will prove very useful to a large class of readers. - Extract from a letter from Garrett P. Serviss, B.S.

\section{History of Chemistry \\ By Sir Edward Thorpe, C.B., LL.D., F.R.S.}

Author of " Essays in Historical Chemistry," "' Humphry

Davy : Poet and Philosopher," " Joseph Priestley," etc.

12 Illustrations. Twovols. Vol.I-circa 2000 B.C. to I 850 A.D. Vol. II-I850 A.D. to date

The author traces the evolution of intellectual thought in the progress of chemical investigation, recognizing the various points of view of the different ages, giving due credit even to the ancients. It has been necessary to curtail many parts of the History, to lay before the reader in unlimited space enough about each age to illustrate its tone and spirit, the ideals of the workers, the gradual addition of new points of view and of new means of investigation.

\section{The History of Old Testament Criticism}

\section{By Archibald Duff}

Professor of Hebrew and OId Testament Theology In the United College, Bradford

\section{I6 Illusirations}

The author sets forth the critical views of the Hebrews concerning their own literature, the early Christian treatment of the Old Testament, criticism by the Jewish rabbis, and criticism from Spinoza to Astruc, and from Astruc until the present.

"The treatment of the subject is scholarly and thorough, and fully accepts the labors and the results of modern biblical criticism." - Watchma 


\title{
A History of the Sciences
}

\section{History of New Testament Criticism}

\author{
By F. C. Conybeare, M.A.
}

Late Pellow and Praelector of University College, Oxford, Fellow of the British Academy

\section{Illustrations}

"The volume is the work of a distinguished scholar. . . . It is written in the racy popular style but .. . it is not so much history as a eulogy. As a eulogistic summing up of the work this book may be called a success."-Christian Advocate.

\section{History of Anthropology}

By Alfred C. Haddon, M.A., Sc.D., F.R.S.

Fellow of Christ's College, University Reader in Ethnology, Cambridge

9 Illustrations

"Anthropology has been treated in this little book in a way to rouse the enthusiasm of which it is worthy . . . it will help the enquirer to understand the present status of the science, and direct him to the proper books. . . the book is one to be possessed by all students of the "science of man." "-Chicago Eve. Post.

\section{History of Geology}

By Horace B. Woodward, F.R.S., F.G.S.

Assistant Director of Geological Survey of England and Wales I4 Illustrations

"Two hundred pages of thoroughly digested information on the principal geological discoveries, how they have been arrived at, and some account of the workers to whom the discoveries are due."-Chicago Inter-Ocean.

\section{History of Biology \\ By L. C. Miall, F.R.S. \\ II Illustrations}

"A wise and instructive book. It is scholarly but restrained, so that the reader is not overwhelmed with too much learning, It is a model of terseness, yet it has that picturesqueness of illustration which is necessary if a history is to grip the ordinary mind."-Nature. 


\section{A History of the Sciences}

\section{History of Ancient Philosophy By A. W. Benn \\ 9 Illustrations}

"A valuable little handbook on philosophy. The author gives a digest of all the ancient schools of philosophy, their influence on one another, and a rather extended account of Socrates, Plato, and Aristotle. Mr. Benn is the author of standard volumes on the philosophers and philosophy of Greece."-Brooklyn Eagle.

\section{History of Modern Philosophy By A. W. Benn 10 Illustratious}

"The author presents an admirable popular survey of the developments in philosophy from the beginning of what is known as the philosophical renaissance down to the present day. He closes his book with a brief reference to pragmatism and the metaphysics of Bergson."

N. Y, Times.

\section{The History of Psychology}

A Sketch and an Interpretation.

Vol. I-From the Earliest Time to John Locke.

Vol. II-From John Locke to the Present Time.

By James Mark Baldwin, Ph.D., D.Sc., LL.D. 2 vols.

\section{The History of Geography}

By Dr. John Scott Keltie, F.R.G.S.

Further volumes are in active preparation 
BF81. $82: 1$

SCIII

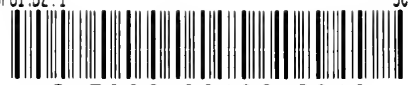

35002001823819

Baidwin, James Mark

History of psychology: a sketch and an I 


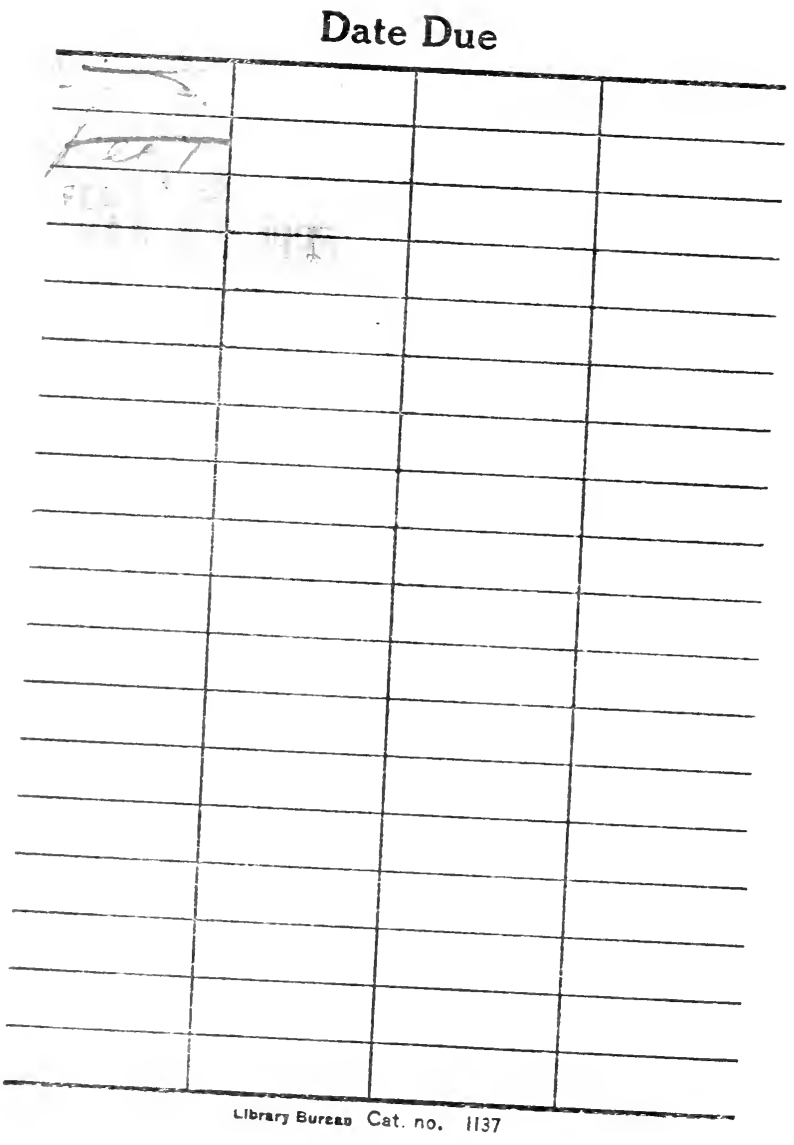


BH
31
$B 2$

Baldwin

History of psycholog.

\section{2}

$B F$

81

B2

1

88762

ir 
Hold 